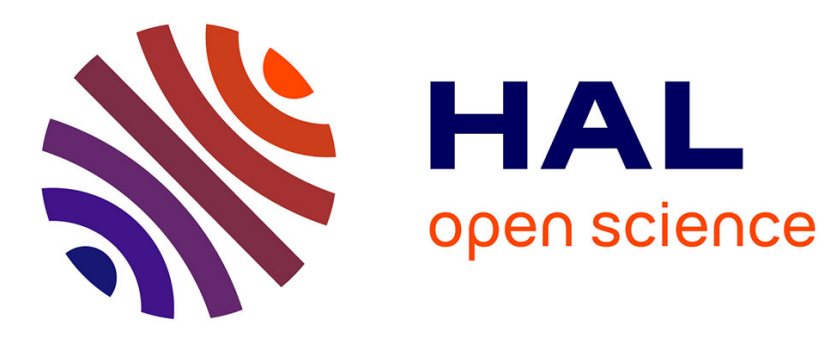

\title{
Electronic Structure of Ru2(II,II) Oxypyridinates: Synthetic, Structural, and Theoretical Insights into Axial Ligand Binding
}

Tristan R. Brown, Brian S. Dolinar, Elisabeth A. Hillard, Rodolphe Clerac, John F. Berry, Rodolphe Cleracclerac

\section{To cite this version:}

Tristan R. Brown, Brian S. Dolinar, Elisabeth A. Hillard, Rodolphe Clerac, John F. Berry, et al.. Electronic Structure of Ru2(II,II) Oxypyridinates: Synthetic, Structural, and Theoretical Insights into Axial Ligand Binding. Inorganic Chemistry, 2015, 54, pp. 8571-8589. 10.1021/acs.inorgchem.5b01241 . hal-01199215

\section{HAL Id: hal-01199215 \\ https://hal.science/hal-01199215}

Submitted on 1 Oct 2017

HAL is a multi-disciplinary open access archive for the deposit and dissemination of scientific research documents, whether they are published or not. The documents may come from teaching and research institutions in France or abroad, or from public or private research centers.
L'archive ouverte pluridisciplinaire HAL, est destinée au dépôt et à la diffusion de documents scientifiques de niveau recherche, publiés ou non, émanant des établissements d'enseignement et de recherche français ou étrangers, des laboratoires publics ou privés. 


\title{
Electronic Structure of $\mathrm{Ru}_{2}$ (II,II) Oxypyridinates: Synthetic, Structural, and Theoretical Insights into Axial Ligand Binding
}

\author{
Tristan R. Brown, ${ }^{\dagger}$ Brian S. Dolinar, ${ }^{\dagger}$ Elizabeth A. Hillard, ${ }^{\ddagger}$, Rodolphe Clérac, $^{\ddagger}, \S$ and John F. Berry ${ }^{*} \dagger$ \\ ${ }^{\dagger}$ Department of Chemistry, University of Wisconsin-Madison, 1101 University Avenue, Madison, Wisconsin 53706, United States \\ ${ }^{\ddagger}$ CNRS and ${ }^{\S}$ Univ. Bordeaux, CRPP, UPR 8641, F-33600 Pessac, France
}

\begin{abstract}
Reduction of $(4,0)-\mathrm{Ru}_{2}(\mathrm{chp})_{4} \mathrm{Cl}$ (1) (chp = 6-chloro-2-oxypyridinate) with $\mathrm{Zn}$ or $\mathrm{FeCl}_{2}$ yields a series of axial ligand adducts of the $\mathrm{Ru}_{2}(\mathrm{II}, \mathrm{II})$ species $\mathrm{Ru}_{2}(\mathrm{chp})_{4}(\mathrm{~L})$, with $\mathrm{L}=$ tetrahydrofuran (2), dimethyl sulfoxide (DMSO; 3), $\mathrm{PPh}_{3}$ (4), pyridine (5), or $\mathrm{MeCN}(6)$. $\mathrm{Zn}$ reduction in noncoordinating solvents such as toluene or $\mathrm{CH}_{2} \mathrm{Cl}_{2}$ leads to the dimeric species $\left[\mathrm{Ru}_{2}(\mathrm{chp})_{4}\right]_{2}(7)$ or $\left[\mathrm{Ru}_{2}(\mathrm{chp})_{4}\right]_{2}\left(\mathrm{ZnCl}_{2}\right)(8)$, whereas addition of strongly $\sigma$ donating ligands such as $\mathrm{CO}$ causes cleavage of the $\mathrm{Ru}-\mathrm{Ru}$ bond. Density functional theory (DFT) models of these complexes, the axially free species, and the axial adducts of several other potential ligands $\left(\mathrm{H}_{2} \mathrm{O}, \mathrm{NH}_{3}, \mathrm{CH}_{2} \mathrm{Cl}_{2}\right.$, S-bound DMSO, $\mathrm{N}_{2}$, and $\mathrm{CO}$ ) indicate that these compounds can be divided into three

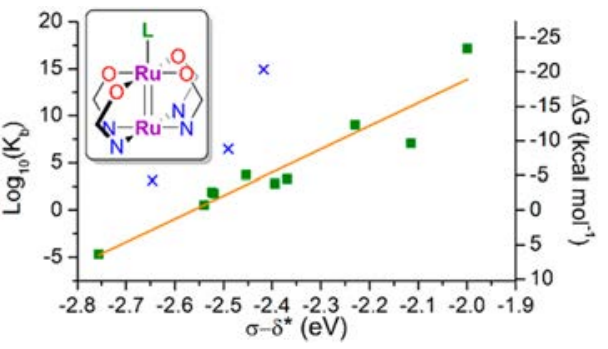

distinct categories, based on their $\mathrm{Ru}-\mathrm{Ru}$ bond length and electronic structure. Compounds 2, 3, 5, 6, 7, and 8, the hypothetical axially free species, and adducts of $\mathrm{H}_{2} \mathrm{O}$ and $\mathrm{NH}_{3}$ fit in Category 1 with a $\left(\delta^{*}\right)^{2}\left(\pi^{*}\right)^{2}$ ground state, as indicated by their electronic spectra, magnetic properties, and $\mathrm{Ru}-\mathrm{Ru}$ bond distances. However, compound 4 and the $\mathrm{CH}_{2} \mathrm{Cl}_{2}$ adduct (Category 2 ) show a pseudo-Jahn-Teller distortion and spectroscopic signs of $\delta^{*} / \pi^{*}$ orbital mixing suggestive of a new electronic ground state intermediate between the $\left(\delta^{*}\right)^{2}\left(\pi^{*}\right)^{2}$ and $\left(\delta^{*}\right)^{1}\left(\pi^{*}\right)^{3}$ configurations. Category 3 consists of the hypothetical adducts of $\mathrm{N}_{2}$, Sbound DMSO, and CO, all of which are predicted to have a $\left(\delta^{*}\right)^{1}\left(\pi^{*}\right)^{3}$ configuration. Electronic spectra were recorded and assigned using time-dependent DFT, allowing assignment of a band in the $10000-13000 \mathrm{~cm}^{-1}$ range as the $\delta \rightarrow \pi^{*}$ transition. The axial ligand's $\pi$-acid character heavily influences the $\delta^{*}-\pi^{*}$ gap, and thereby the ground-state electronic configuration, but not the axial ligand binding strength, which is dictated more by the $\sigma$-donor character of the ligands. Thus, this work greatly expands the number of axial ligand adducts known for $\mathrm{Ru}_{2}(\mathrm{II}, \mathrm{II})$ complexes supported by $\mathrm{N}, \mathrm{O}$-donor ligands and provides a predictive theoretical framework for their stability and electronic structures.
\end{abstract}

\section{INTRODUCTION}

The coordination chemistry of $\mathrm{Ru}-\mathrm{Ru}$ multiply bonded transition metal complexes is currently of interest due to unique structural, ${ }^{1-5}$ electrochemical/electronic, ${ }^{6-10}$ magnetic, ${ }^{11-13}$ chemical, ${ }^{14-16}$ and catalytic $^{17}$ properties of the compounds. Recently, we investigated several $\mathrm{Ru}_{2}$ paddlewheel complexes that support an electrophilic terminal nitride ${ }^{18}$ capable of performing nitrogen-atom transfer (NAT) chemistry (Scheme 1a). In particular, $\mathrm{Ru}_{2}\left(\mathrm{D}\left(3,5-\mathrm{Cl}_{2}\right) \mathrm{PhF}\right)_{4} \mathrm{~N}(\mathrm{D}(3,5-$ $\left.\mathrm{Cl}_{2}\right) \mathrm{PhF}=N, N^{\prime}$-bis $(3,5$-dichlorophenyl)formamidinate $)$ has been shown to perform intramolecular NAT into a ligand $\mathrm{C}-\mathrm{H}$ bond, ${ }^{19,20}$ and $\mathrm{Ru}_{2}(\mathrm{chp})_{4} \mathrm{~N}$ (chp = 6-chloro-2-oxypyridinate) has been shown to perform intermolecular NAT to triphenylphosphine in a complete synthetic cycle. ${ }^{21}$ In addition to ongoing explorations aimed at expanding the scope of $\mathrm{Ru}_{2}$-supported NAT chemistry, we are also interested in exploring potential alternative, azide-free mechanisms for nitride formation using $\mathrm{N}_{2}$, ${ }^{22}$ ammonia, ${ }^{23}$ or hydrazine ${ }^{24}$ as cheap and abundant $\mathrm{N}$ atom sources (Scheme $1 \mathrm{~b}$ ). The first step in any such mechanism would be the formation of $\mathrm{a} \mathrm{R}=$ $\mathrm{Ru}$ doubly bonded $\mathrm{Ru}_{2}$ (II,II) complex with the appropriate $\mathrm{N}$ atom source bound as an axial ligand. However, even this initial step presents a challenge, as $\mathrm{Ru}_{2}(\mathrm{II}, \mathrm{II})$ complexes are not currently known to bind these axial ligands.

As has been shown with other $\mathrm{M}_{2}$ systems, coordination to one metal is heavily influenced by the presence of a second, bonded metal, giving unusual chemistry at the axial position. ${ }^{25-28}$ The Lewis acidity of $\mathrm{Ru}_{2}$ (II,II) complexes varies extensively as a function of the equatorial ligand system, with $\mathrm{O}, \mathrm{O}-, \mathrm{N}, \mathrm{O}-$, and $\mathrm{N}, \mathrm{N}$-types of ligands supporting complexes with different axial ligands (Chart 1 ). $\mathrm{Ru}_{2}$ tetracarboxylate (O,O type) complexes are known to bind a variety of neutral axial ligands, such as $\mathrm{H}_{2} \mathrm{O}$, tetrahydrofuran (THF), and acetone, ${ }^{29}$ but are unstable to $\mathrm{CO}, \mathrm{PPh}_{3}$, pyridine, isocyanides, and occasionally $\mathrm{MeCN}{ }^{30}$ Incorporation into a coordination polymer allows for the stabilization of complexes with pyridine or $7,7^{\prime}, 8,8^{\prime}$-tetracyanoquinodimethane derivatives. ${ }^{31-41}$ Amidinate $\left(\mathrm{N}, \mathrm{N}\right.$-type) complexes of $\mathrm{Ru}_{2}(\mathrm{II}, \mathrm{II})$ are significantly less Lewis acidic than their carboxylate analogues and can therefore be prepared without any axial donors present. ${ }^{42,43}$ However, several $\pi$-acid ligands (e.g., CO) that sever the $\mathrm{Ru}-\mathrm{Ru}$ bond of the carboxylate analogues can bind to $\mathrm{Ru}_{2}$ (II,II) amidinate 
Scheme $1^{a}$

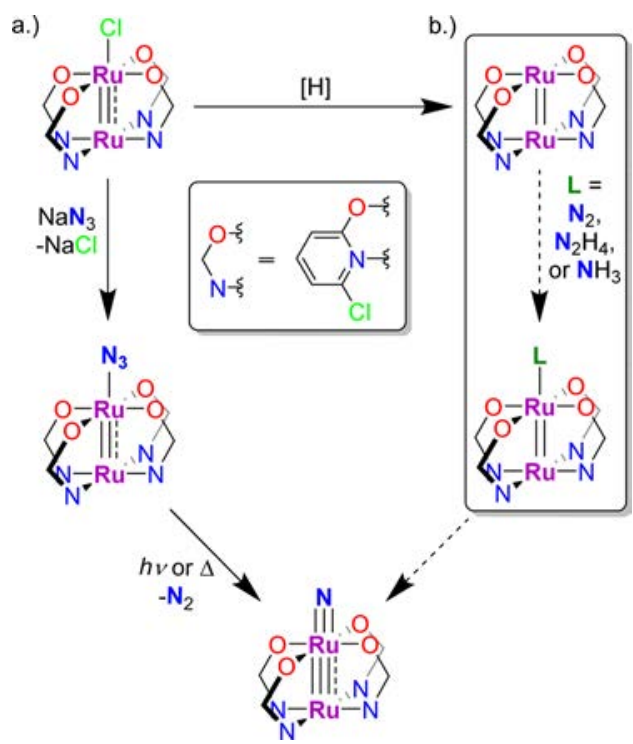

${ }^{a}$ (a) Previous synthetic route to $\mathrm{Ru}-\mathrm{Ru}$-nitride complexes. (b) Hypothetical alternative route, with the feasibility of the first step to be explored in this work.

Chart 1. Representative Structures of the Classes of $\mathrm{Ru}_{2}$ (II,II) Complexes with O,O-, N,O-, and N,N-Donor Ligands

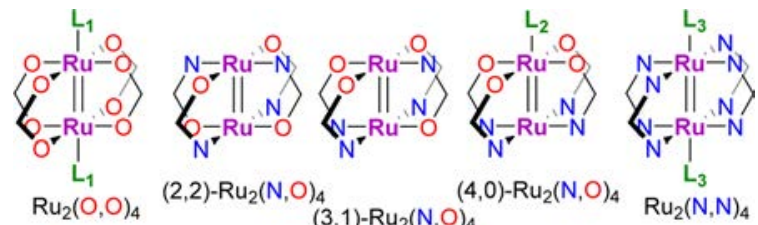

$\mathrm{L}_{1}=$ alcohols, ethers, ketones; $\mathrm{L}_{2}=\mathrm{THF} ; \mathrm{L}_{3}=$ Nothing, $\mathrm{CO}, \mathrm{MeCN}$

compounds. ${ }^{15,43}$ Notably, $\mathrm{Ru}_{2}$ amidinate compounds are not Lewis acidic enough to bind $\mathrm{N}_{2}$. We hypothesize that compounds with an intermediate equatorial ligand field strength between carboxylate and amidinate ligands (i.e., those with a set of mixed N,O-donor ligands) could be Lewis acidic enough to bind a variety of axial ligands as well as being stable to $\pi$-acceptors, so that they could be used to test the feasibility of the reaction pathways outlined in Scheme 1b. To this point, however, $\mathrm{N}, \mathrm{O}$-supported $\mathrm{Ru}_{2}$ (II,II) compounds have only been reported to bind THF as an axial ligand, ${ }^{44,45}$ highlighting the need for a fundamental exploration of the scope of axial ligands that can be supported.

The electronic structure of $\mathrm{Ru}_{2}$ (II,II) complexes is highly relevant to this fundamental study. These complexes exist with a $\mathrm{Ru}=\mathrm{Ru}$ doubly bonded electron configuration that can be represented as $\sigma^{2} \pi^{4} \delta^{2}\left(\delta^{*}, \pi^{*}\right)^{4}$, which emphasizes the fact that the $\delta^{*}$ and $\pi^{*}$ orbitals are quite close in energy. The size and direction of the splitting $\left(\Delta=E\left(\pi^{*}\right)-E\left(\delta^{*}\right)\right)$ between the $\mathrm{Ru}-\mathrm{Ru} \pi^{*}$ and $\delta^{*}$ orbitals that hold the highest-energy electrons is determined by two effects. The extent of $\pi$ donation from the equatorial ligands modifies the metal $\delta^{*}$ orbitals and the $\pi$-acceptance or $\pi$-donation of any axial ligands serves to modify the energy of the $\mathrm{Ru}_{2} \pi^{*}$ orbitals (Chart 2). ${ }^{46}$ When the equatorial ligands are strongly $\pi$-donating, making $\Delta$ $<0$, the $D_{4 h}$-symmetric $\mathrm{Ru}_{2}$ (II,II) electronic ground state is ${ }^{1} \mathrm{~A}_{\mathrm{lg}}\left(\pi^{*}\right)^{4}$. This occurs in the known $(\mathrm{N}, \mathrm{N})$-type (amidinate)
Chart 2. Three Possible Electronic States Available to $\mathrm{Ru}_{2}(\mathrm{II}, \mathrm{II})$ Compounds via the $\left(\delta^{*}, \pi^{*}\right)^{4}$ Configuration

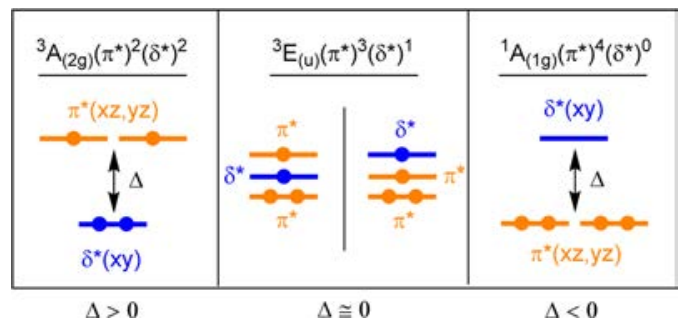

paddlewheel complexes, which are then diamagnetic. ${ }^{43}$ When the equatorial $\pi$-donation into the $\mathrm{Ru}_{2} \delta^{*}$ orbital is weaker, $\Delta$ > 0 , so the electronic ground state is ${ }^{3} \mathrm{~A}_{2 \mathrm{~g}}\left(\delta^{*}\right)^{2}\left(\pi^{*}\right)^{2}$. This condition holds for the known (O,O)-type (carboxylate) paddlewheel complexes. ${ }^{47}$ When $\Delta \approx 0$, the electronic ground state is predicted to be the orbitally degenerate ${ }^{3} \mathrm{E}_{\mathrm{u}}\left(\delta^{*}\right)^{1}\left(\pi^{*}\right)^{3}$, but this state has, to our knowledge, never been observed in any $\mathrm{d}^{6}-\mathrm{d}^{6}$ metal-metal bonded system.

The complexes studied here have four N,O donor ligands, 6chloro-2-oxypyridinate (chp), which are arranged about the $\mathrm{Ru}_{2}$ core in the $(4,0)$-configuration, having all $\mathrm{N}$ atoms bound to one $\mathrm{Ru}$ atom and all $\mathrm{O}$ atoms bound to the other $\mathrm{Ru}$ atom (see Chart 1). The molecular symmetry is therefore $C_{4}$ at best, for which the $D_{4 h}$ electronic states ${ }^{1} \mathrm{~A}_{1 g},{ }^{3} \mathrm{~A}_{2 g}$, and ${ }^{3} \mathrm{E}_{\mathrm{u}}$ transform as ${ }^{1} \mathrm{~A},{ }^{3} \mathrm{~A}$, and ${ }^{3} \mathrm{E}$. We will henceforth refer to these states under the less-restrictive $C_{4}$ symmetry labels for consistency. The known $(\mathrm{N}, \mathrm{O})$-type $\mathrm{Ru}_{2}(\mathrm{II}, \mathrm{II})$ paddlewheel complexes are found in the ${ }^{3} \mathrm{~A}$ ground state, though the only known axial adducts of this class of compounds are the dimer $(3,1)-\left[\mathrm{Ru}_{2}(\operatorname{chp})_{4}\right]_{2}$ in which the axial site at the $\mathrm{Ru}-\mathrm{Ru}$ bond is occupied by an $\mathrm{O}$ atom from the equatorial ligand of the next $\mathrm{Ru}_{2}$ unit, ${ }^{48}$ $\mathrm{Ru}_{2}$ (fhp) ${ }_{4}$ (THF) (fhp = 6-fluoro-2-oxypyridinate), ${ }^{44}$ and $\mathrm{Ru}_{2}$ (chp) $)_{4}$ (THF). ${ }^{45}$ Compounds with ${ }^{3} \mathrm{~A} \mathrm{Ru}-\mathrm{Ru}$ bonds have been reported to be unstable to $\pi$-withdrawing axial ligands, ${ }^{30,49}$ but this empirical result does not have a firm basis in electronic structure. Given that placing a $\pi$-withdrawing axial ligand on a $\mathrm{Ru}_{2}(\mathrm{~N}, \mathrm{O})_{4}$ complex might favor the ${ }^{3} \mathrm{E}$ state, it is important to determine whether approaching this state creates an intrinsic instability in the system. Because of the demonstrated NAT ability of $\mathrm{Ru}_{2}(\operatorname{chp})_{4} \mathrm{~N}{ }^{21}$ we sought to investigate the Lewis acidity and stability of the neutral $\mathrm{Ru}_{2}(\mathrm{chp})_{4}$ core using a synthetic and computational approach.

Herein, we report the reduction of $\mathrm{Ru}_{2}(\operatorname{chp})_{4} \mathrm{Cl}$ (1) to $\mathrm{Ru}_{2}(\mathrm{chp})_{4}$ in the presence of a wide variety of potential axial ligands. The compounds investigated here are the previously reported ${ }^{45} \mathrm{Ru}_{2}(\mathrm{chp})_{4}$ (THF) (2) as well as the new axial adducts $\mathrm{Ru}_{2}(\mathrm{chp})_{4}(\mathrm{DMSO})$ (3; DMSO = dimethyl sulfoxide), $\mathrm{Ru}_{2}(\mathrm{chp})_{4}\left(\mathrm{PPh}_{3}\right)$ (4), $\mathrm{Ru}_{2}(\mathrm{chp})_{4}(\mathrm{py})$ (5), and $\mathrm{Ru}_{2}(\mathrm{chp})_{4}$ $(\mathrm{MeCN})(6)$ and the new dimeric compounds $\left[\mathrm{Ru}_{2}(\mathrm{chp})_{4}\right]_{2}$ (7) and $\left[\mathrm{Ru}_{2}(\mathrm{chp})_{4}\right]_{2}\left(\mathrm{ZnCl}_{2}\right)(8)$. Aside from 7 , all of these compounds were characterized by X-ray crystallography and electronic absorption spectroscopy. Magnetic susceptibility data were collected for 4,5 , and 8 . To further understand the effect of the axial ligand on the $\mathrm{Ru}_{2}$ (II,II) electronic structure and identify the factors governing the strength of axial ligation, density functional theory (DFT) geometry optimizations, single-point calculations, and frequency calculations were performed on complexes $\mathbf{2 - 8}$ as well as several other hypothetical adducts of interest. Time-dependent density functional theory (TDDFT) calculations were performed on 
the synthesized adducts to aid in assignment of their electronic absorption spectra.

\section{EXPERIMENTAL SECTION}

2.1. General. Except where otherwise noted, all syntheses, product isolations, and characterizations were performed under a dry $\mathrm{N}_{2}$ atmosphere using established Schlenk techniques or in a glovebox. Reagent-grade DMSO and acetone as well as deionized water were degassed and used without further purification. All other solvents were dried, purified, and degassed according to standard techniques. The Hchp ligand was recrystallized from hexane prior to use. $\mathrm{PPh}_{3}$ was recrystallized from ethanol. The preparation of $\mathrm{Ru}_{2}(\mathrm{OAc})_{4} \mathrm{Cl}$ was adapted from the literature ${ }^{50}$ by having the reaction mixture open to air and refluxing for $2 \mathrm{~d}$. $\mathrm{Ru}_{2}(\mathrm{chp})_{4} \mathrm{Cl}(\mathbf{1})$ was prepared according to the method developed in our lab.

2.2. Preparation of $\mathrm{Ru}_{2}$ (II,II) Compounds. 2.2.1. Preparation of $\mathrm{Ru}_{2}(\mathrm{chp})_{4}(\mathrm{THF})$ (2). Crystals containing the known compound $\mathrm{Ru}_{2}(\mathrm{chp})_{4}$ (THF) as a new solvatomorph were prepared according to a published procedure, ${ }^{45}$ and solutions suitable for UV-vis spectroscopic analysis were prepared by performing the same reaction in more dilute conditions and using the fresh filtrate. UV-vis, THF solution $\left(\nu_{\max } \mathrm{cm}^{-1}\left(\varepsilon, \mathrm{M}^{-1} \mathrm{~cm}^{-1}\right)\right): 12600(80), 15400(130)$, 18800 (370), 20800 (640), 22600 (790).

2.2.2. Preparation of $R u_{2}(c h p)_{4}(D M S O)$ (3). To a Schlenk flask containing 1 (147 mg, $0.195 \mathrm{mmol})$ and zinc dust $(637 \mathrm{mg}, 9.74$ mmol), DMSO (30 mL) was added. The dark purple mixture was stirred for $2 \mathrm{~h}$, during which a color change to dark orange-brown was observed. After filtering through Celite, the filtrate was layered with water, and dark yellow-brown, plate-shaped crystals formed over $6 \mathrm{~d}$. The crystals proved metastable in these conditions and could not be isolated and characterized as a dry product without removing all DMSO from the structure. ${ }^{51}$ Solutions of $\mathrm{Ru}_{2}(\mathrm{chp})_{4}(\mathrm{DMSO})$ suitable for UV-vis spectroscopic analysis were prepared directly from the reaction filtrate. UV-vis, DMSO solution $\left(\nu_{\max } \mathrm{cm}^{-1}\left(\varepsilon, \mathrm{M}^{-1} \mathrm{~cm}^{-1}\right)\right)$ : 12600 (84), 15600 (110), 20900 (830).

2.2.3. Preparation of $R u_{2}(c h p)_{4}\left(P P h_{3}\right)$ (4). To a Schlenk flask containing 1 (100 mg, $0.133 \mathrm{mmol})$, zinc dust $(435 \mathrm{mg}, 6.65 \mathrm{mmol})$, and triphenylphosphine $(349 \mathrm{mg}, 1.33 \mathrm{mmol})$, THF $(30 \mathrm{~mL})$ was added. The dark purple mixture was stirred for $1.5 \mathrm{~h}$, during which a color change to dark olive-green was observed. After this mixture was filtered through Celite, the resulting dark green filtrate was carefully layered with hexane, yielding (after $2 \mathrm{~d}$ ) olive-green needle-shaped crystals. The crystals were collected in air, washed with hexane (10 $\mathrm{mL}$ ), and then dried in vacuo for $16 \mathrm{~h}$, giving $\mathrm{Ru}_{2}(\mathrm{chp})_{4}\left(\mathrm{PPh}_{3}\right) \cdot \mathrm{THF}$. Yield: $108 \mathrm{mg}$ (77.3\%). Anal. Calcd for $\mathrm{C}_{38} \mathrm{H}_{27} \mathrm{~N}_{4} \mathrm{O}_{5} \mathrm{PCl}_{4} \mathrm{Ru}_{2}$ : C 48.01, H 3.36, N 5.33\%. Found: C 47.98, H 3.38, N 5.34\%. IR (ATR, $\mathrm{cm}^{-1}$ ): 3049 vw, 2979 vw, 2857 vw, 1602 s, 1529 m, 1467 s, 1434 s, 1391 m, $1358 \mathrm{~m}, 1218 \mathrm{w}, 1167 \mathrm{~s}, 1097 \mathrm{w}, 1066 \mathrm{w}, 1015 \mathrm{~m}, 926 \mathrm{~m}, 857 \mathrm{w}, 782$ s, $750 \mathrm{~m}, 724 \mathrm{~m}, 711 \mathrm{~s}, 697 \mathrm{~s}, 618 \mathrm{w}, 605$ w. Matrix-assisted laser desorption/ionization time-of-flight mass spectrometry (MALDI-TOF MS; $m / z): 718\left[\mathrm{M}-\mathrm{PPh}_{3}\right]^{+}, 811\left[\mathrm{M}-\mathrm{PPh}_{3}+\mathrm{chp}-\mathrm{Cl}+\mathrm{H}\right]^{+}, 903$ $[\mathrm{M}-\mathrm{Ph}]^{+}, 980[\mathrm{M}]^{+}, 1305\left[\left(\mathrm{M}-\mathrm{PPh}_{3}\right)_{2}-\mathrm{chp}\right]^{+}, 1398[(\mathrm{M}-$ $\left.\left.\mathrm{PPh}_{3}\right)_{2}-\mathrm{Cl}\right]^{+}, 1433\left[\left(\mathrm{M}-\mathrm{PPh}_{3}\right)_{2}\right]^{+}, 1527\left[\left(\mathrm{M}-\mathrm{PPh}_{3}\right)_{2}+\mathrm{chp}-\mathrm{Cl}\right.$ $+\mathrm{H}]^{+}$. X-ray-quality crystals of $\mathrm{Ru}_{2}(\mathrm{chp})_{4}\left(\mathrm{PPh}_{3}\right) \cdot 0$. Stoluene were obtained by a similar procedure, using toluene as the solvent. Solutions of $\mathrm{Ru}_{2}(\mathrm{chp})_{4}\left(\mathrm{PPh}_{3}\right)$ suitable for UV-vis spectroscopic analysis were prepared by performing the same reaction in a more dilute toluene solution and using the fresh filtrate. UV-vis, toluene solution $\left(\nu_{\max }\right.$ $\mathrm{cm}^{-1}, \varepsilon, \mathrm{M}^{-1} \mathrm{~cm}^{-1}$ ): 10800 (55), 17100 (350), 22200 (900).

2.2.4. Preparation of $\mathrm{Ru}_{2}(\mathrm{chp})_{4}$ (py) (5). To a Schlenk flask containing 1 (201 mg, $0.267 \mathrm{mmol})$ and zinc dust (1.00 g, 15.3 $\mathrm{mmol})$, pyridine $(50 \mathrm{~mL})$ was added. The dark purple mixture was stirred for $2.5 \mathrm{~h}$, during which a color change to yellow-brown was observed. After the mixture was filtered through Celite, the resulting reddish-orange filtrate was carefully layered with hexane, yielding (after $3 \mathrm{~d}$ ) dark orange needle-shaped crystals under a yellow solution. The crystals were collected in air, washed with acetonitrile $(20 \mathrm{~mL})$, ether $(30 \mathrm{~mL})$, and hexanes $(50 \mathrm{~mL})$, and then dried in vacuo for $16 \mathrm{~h}$. Yield: $131 \mathrm{mg}$ (61.5\%). Anal. Calcd for $\mathrm{C}_{25} \mathrm{H}_{17} \mathrm{~N}_{5} \mathrm{O}_{4} \mathrm{Cl}_{4} \mathrm{Ru}_{2}$ : C 37.75,
H 2.15, N 8.81\%. Found: C 37.81, H 2.16, N 8.84\%. IR (ATR, $\mathrm{cm}^{-1}$ ): 3099 vw, $3063 \mathrm{vw}, 1942 \mathrm{w}, 1602$ s, $1529 \mathrm{~m}, 1470 \mathrm{~s}, 1437 \mathrm{~s}, 1402 \mathrm{w}$, 1392 m, 1364 m, 1219 m, 1167 m, 1068 w, 1037 w, 1011 m, 927 m, 865 w, 852 w, 777 s, 758 w, 726 m, 703 m, 635 m, 619 w. MALDITOF $(\mathrm{m} / z): 718[\mathrm{M}-\mathrm{py}]^{+}, 797[\mathrm{M}]^{+}, 811[\mathrm{M}-\mathrm{py}+\mathrm{chp}-\mathrm{Cl}+$ $\mathrm{H}]^{+}, 876[\mathrm{M}+\mathrm{py}]^{+}, 1398\left[(\mathrm{M}-\mathrm{py})_{2}-\mathrm{Cl}\right]^{+}, 1433\left[(\mathrm{M}-\mathrm{py})_{2}\right]^{+}$, $1526\left[(\mathrm{M}-\mathrm{py})_{2}+\mathrm{chp}-\mathrm{Cl}\right]^{+}$. UV-vis, pyridine solution $\left(\nu_{\max } \mathrm{cm}^{-1}\right.$ $\left.\left(\varepsilon, \mathrm{M}^{-1} \mathrm{~cm}^{-1}\right)\right): 11800$ (80), 17700 (230), 20900 (900), 22100 (1000).

2.2.5. Preparation of $\mathrm{Ru}_{2}(\mathrm{chp})_{4}(\mathrm{MeCN})$ (6). $\mathrm{FeCl}_{2} \cdot 4 \mathrm{H}_{2} \mathrm{O}(26.4 \mathrm{mg}$, $0.133 \mathrm{mmol}$ ) was dissolved in $10 \mathrm{~mL}$ of hot $\mathrm{MeCN}$, and the resulting solution was transferred by cannula to a Schlenk tube containing 1 (100 mg, $0.133 \mathrm{mmol}$ ). The mixture was left to stand without stirring. After one month, the mixture was filtered, and the solids were dried under vacuum. The resulting orange crystals of 6 were mechanically separated from the brown powder side-product and remaining $\mathbf{1}$, and were collected in a dry atmosphere. Yield: $6 \mathrm{mg}(6 \%)$. IR (ATR, $\mathrm{cm}^{-1}$ ): $3190 \mathrm{br}, 2989 \mathrm{vw}, 2927 \mathrm{vw}, 2311 \mathrm{~m}, 2282 \mathrm{~m}, 1643 \mathrm{~m}, 1599 \mathrm{~m}$, 1535 w, 1433 m, 1414 m, 1368 m, 1264 w, 1171 w, 1030 m, 938 m, $867 \mathrm{~s}, 789 \mathrm{w}, 722 \mathrm{w}, 654 \mathrm{w}, 633 \mathrm{w}$. Low yields and long reaction times precluded more extensive characterization of $\mathbf{6}$. Solutions suitable for UV-vis spectroscopic analysis were generated using conditions similar to those for 2, but using acetonitrile as the solvent. UV-vis, MeCN solution $\left(\nu_{\max }, \mathrm{cm}^{-1}\left(\varepsilon, \mathrm{M}^{-1} \mathrm{~cm}^{-1}\right)\right): 11700$ (76), 16200 (130), 20900 (680), 22900 (960).

2.2.6. Preparation of $\left[R u_{2}(\mathrm{chp})_{4}\right]_{2}$ (7). Yellow-brown crystals of 3 generated from $1(147 \mathrm{mg}, 0.195 \mathrm{mmol})$ were collected in air, washed with acetonitrile $(5 \mathrm{~mL})$, and then dried in vacuo for $16 \mathrm{~h}$, during which a color change to dark brown was observed. Yield: $84 \mathrm{mg}$ (60\%). Anal. Calcd for $\mathrm{C}_{40} \mathrm{H}_{24} \mathrm{~N}_{8} \mathrm{O}_{8} \mathrm{Cl}_{8} \mathrm{Ru}_{4}$ : C 33.54, $\mathrm{H} 1.69, \mathrm{~N} 7.82 \%$. Found: C 33.21, H 1.70, N 7.66\%. IR (ATR, $\mathrm{cm}^{-1}$ ): $3082 \mathrm{vw}, 1605 \mathrm{~m}$, $1528 \mathrm{~m}, 1467 \mathrm{~m}, 1436 \mathrm{~s}, 1392 \mathrm{~m}, 1361 \mathrm{~m}, 1335 \mathrm{~m}, 1220 \mathrm{~m}, 1176 \mathrm{w}$, 1165 m, 1072 w, 1016 m, 927 m, 874 w, 852 w, 791 w, 779 s, 731 m, $723 \mathrm{~m}, 712 \mathrm{~m}, 636 \mathrm{~m}$. MALDI-TOF $(\mathrm{m} / z): 718\left[\mathrm{M}-\mathrm{Ru}_{2}(\mathrm{chp})_{4}\right]^{+}$, $811\left[\mathrm{M}-\mathrm{Ru}_{2}(\mathrm{chp})_{4}+\mathrm{chp}-\mathrm{Cl}+\mathrm{H}\right]^{+}, 1305[\mathrm{M}-\mathrm{chp}]^{+}, 1398[\mathrm{M}-$ $\mathrm{Cl}]^{+}, 1433[\mathrm{M}]^{+}$.

2.2.7. Preparation of $\left[R u_{2}(\mathrm{Chp})_{4}\right]_{2}\left(\mathrm{ZnCl}_{2}\right)$ (8). To a Schlenk flask containing 1 (163 mg, $0.217 \mathrm{mmol})$ and zinc dust (140 mg, 2.14 mmol), $\mathrm{CH}_{2} \mathrm{Cl}_{2}(80 \mathrm{~mL})$ kept at $-78{ }^{\circ} \mathrm{C}$ was added. The resulting dark purple mixture was warmed to $-10{ }^{\circ} \mathrm{C}$ and stirred for $3.5 \mathrm{~h}$, during which a color change to dark red was observed. After the mixture was filtered through Celite into a flask kept at $-78{ }^{\circ} \mathrm{C}$, precooled hexane $(320 \mathrm{~mL})$ was stirred into the red filtrate. The mixture was removed from the cold bath and shielded from light for several hours, during which a precipitate formed. The mixture was returned to $-78{ }^{\circ} \mathrm{C}$ and filtered, giving red-brown solids that were dried in vacuo and collected under an inert atmosphere. Yield: $156 \mathrm{mg}$ (89.4\%). Anal. Calcd for $\mathrm{C}_{40.5} \mathrm{H}_{25} \mathrm{~N}_{8} \mathrm{O}_{8} \mathrm{Cl}_{11} \mathrm{Ru}_{4} \mathrm{Zn}\left(8 \cdot 0.5 \mathrm{CH}_{2} \mathrm{Cl}_{2}\right)$ : C 30.19, H 1.56, N 6.95\%. Found: C 30.18, H 1.54, N 6.88\%. IR (ATR, $\mathrm{cm}^{-1}$ ): $3086 \mathrm{vw}, 2962 \mathrm{vw}, 1595 \mathrm{~s}, 1543 \mathrm{~m}, 1531 \mathrm{~m}, 1454 \mathrm{~s}, 1434 \mathrm{~s}$, 1405 m, 1393 m, 1359 w, 1326 m, 1264 w, 1231 w, 1179 m, 1166 m, 1088 w, 1072 w, 1018 s, 929 s, 871 w, 852 w, 789 m, 781 m, 731 m, $713 \mathrm{~m}, 650 \mathrm{w}, 637 \mathrm{w}, 624 \mathrm{w}$. MALDI-TOF $(\mathrm{m} / \mathrm{z}): 718[\mathrm{M}-$ $\left.\mathrm{Ru}_{2}(\mathrm{chp})_{4}\left(\mathrm{ZnCl}_{2}\right)\right]^{+}, 811\left[\mathrm{M}-\mathrm{Ru}_{2}(\mathrm{chp})_{4}\left(\mathrm{ZnCl}_{2}\right)+\operatorname{chp}-\mathrm{Cl}+\mathrm{H}\right]^{+}$, $1305\left[\mathrm{M}-\mathrm{ZnCl}_{2}-\mathrm{chp}\right]^{+}, 1433\left[\mathrm{M}-\mathrm{ZnCl}_{2}\right]^{+}, 1468[\mathrm{M}-\mathrm{ZnCl}]^{+}$, $1534[\mathrm{M}-\mathrm{Cl}]^{+}$. X-ray quality crystals of $\mathbf{8} \cdot 1.3 \mathrm{CH}_{2} \mathrm{Cl}_{2}$ were obtained by layering hexanes onto a red solution of $\mathbf{8}$ at room temperature, in the dark. Solutions of $\left[\mathrm{Ru}_{2}(\mathrm{chp})_{4}\right]_{2}\left(\mathrm{ZnCl}_{2}\right)$ suitable for $\mathrm{UV}$-vis spectroscopic analysis were prepared by performing the reduction of 1 in more dilute conditions. The resulting red filtrate was kept at $-78{ }^{\circ} \mathrm{C}$ and shielded from light to minimize oxidation to purple 1 prior to analysis. $\mathrm{UV}-$ vis, $\mathrm{CH}_{2} \mathrm{Cl}_{2}$ solution $\left(\nu_{\max } \mathrm{cm}^{-1}\left(\varepsilon, \mathrm{M}^{-1} \mathrm{~cm}^{-1}\right)\right): 12000$ (81), 15800 (310), 18700 (870), 20200 (1000).

2.3. Physical Measurements. UV-vis measurements were performed using freshly prepared solutions of the reduced compounds with a Miniature BLUE-Wave UV-vis dip probe with a TungstenKrypton light source and a $10 \mathrm{~mm}$ path length tip. Fourier transform infrared spectra were measured on a Bruker Tensor 27 spectrometer using dry $\mathrm{KBr}$ pellet techniques or an ATR module (no matrix). MALDI MS data were recorded at the Mass Spectrometry Facility of 
Table 1. Crystallographic Data

\begin{tabular}{|c|c|c|c|c|c|c|}
\hline & 2.2.4THF & 4.0.5toluene & 4.THF & 5 & 6. $\mathrm{MeCN}$ & $8 \cdot 1.3 \mathrm{CH}_{2} \mathrm{Cl}_{2}{ }^{a}$ \\
\hline $\begin{array}{l}\text { empirical } \\
\text { formula }\end{array}$ & $\begin{array}{l}\mathrm{Ru}_{2}(\mathrm{chp})_{4}(\mathrm{THF}) \\
\quad\left(\mathrm{C}_{4} \mathrm{H}_{8} \mathrm{O}\right)_{2.4}\end{array}$ & $\begin{array}{l}\mathrm{Ru}_{2}(\mathrm{chp})_{4}\left(\mathrm{PPh}_{3}\right) \\
\left(\mathrm{C}_{7} \mathrm{H}_{8}\right)_{0.5}\end{array}$ & $\begin{array}{l}\mathrm{Ru}_{2}(\mathrm{chp})_{4}\left(\mathrm{PPh}_{3}\right) \\
\quad\left(\mathrm{C}_{4} \mathrm{H}_{8} \mathrm{O}\right)\end{array}$ & $\mathrm{Ru}_{2}(\mathrm{chp})_{4}(\mathrm{py})$ & $\begin{array}{l}\mathrm{Ru}_{2}(\mathrm{chp})_{4}\left(\mathrm{CH}_{3} \mathrm{CN}\right)_{0.93}(\mathrm{Cl})_{0.07} \\
\quad\left(\mathrm{CH}_{3} \mathrm{CN}\right)\end{array}$ & $\begin{array}{l}{\left[\mathrm{Ru}_{2}(\mathrm{chp})_{4}\right]_{2}\left(\mathrm{ZnCl}_{2}\right) .} \\
\quad\left(\mathrm{CH}_{2} \mathrm{Cl}_{2}\right)_{1.33}\end{array}$ \\
\hline formula weight & 958.07 & 1024.61 & 1050.65 & 795.38 & 798.02 & 1681.87 \\
\hline temperature, $\mathrm{K}$ & $100(1)$ & $100(1)$ & $100(1)$ & $100(1)$ & $100(1)$ & $100(1)$ \\
\hline$\lambda, \AA$ & 1.54178 & 0.71073 & 1.54178 & 0.71073 & 0.71073 & 0.71073 \\
\hline crystal system & monoclinic & triclinic & monoclinic & monoclinic & triclinic & monoclinic \\
\hline space group & $\mathrm{C} 2 / c$ & $P \overline{1}$ & $P 2_{1} / n$ & $\mathrm{C} 2 / \mathrm{c}$ & $P \overline{1}$ & $P 2_{1} / n$ \\
\hline a, $\AA$ & $23.311(2)$ & $9.314(2)$ & $9.501(1)$ & $16.5485(5)$ & $9.404(3)$ & $14.67(2)$ \\
\hline$b, \AA$ & $17.133(2)$ & $9.601(3)$ & $32.007(3)$ & $12.1926(4)$ & $9.486(3)$ & $22.80(2)$ \\
\hline$c, \AA$ & $18.565(2)$ & $22.177(6)$ & $13.495(1)$ & $13.7919(4)$ & $16.400(4)$ & $18.89(2)$ \\
\hline$\alpha, \operatorname{deg}$ & 90 & $82.934(9)$ & 90 & 90 & $74.106(9)$ & 90 \\
\hline$\beta, \operatorname{deg}$ & $98.481(5)$ & $79.59(1)$ & $99.490(5)$ & $107.840(1)$ & $86.58(2)$ & $103.80(3)$ \\
\hline$\gamma, \operatorname{deg}$ & 90 & $87.230(7)$ & 90 & 90 & 78.911(9) & 90 \\
\hline volume, $\AA^{3}$ & $7334(1)$ & 1935.1(9) & $4047.6(8)$ & $2649.0(1)$ & $1380.8(7)$ & $6136(11)$ \\
\hline$Z$ & 8 & 2 & 4 & 4 & 2 & 4 \\
\hline$\rho_{\text {calo }} \mathrm{g} \mathrm{cm}^{-3}$ & 1.735 & 1.758 & 1.724 & 1.994 & 1.919 & 1.821 \\
\hline $\begin{array}{l}R_{1,}^{b} w R_{2}^{c} \\
\quad[I \geq 2 \sigma(I)]\end{array}$ & $0.0273,0.0644$ & $0.0353,0.0846$ & $0.0221,0.0476$ & $0.0213,0.0534$ & $0.0232,0.0549$ & $0.0516,0.1053$ \\
\hline $\begin{array}{l}R_{1}^{b}, w R_{2}^{c} \\
\text { [all data] }\end{array}$ & $0.0295,0.0659$ & $0.0380,0.0861$ & $0.0279,0.0498$ & $0.0231,0.0544$ & $0.0285,0.0578$ & $0.0934,0.1169$ \\
\hline
\end{tabular}

${ }^{a}$ An additional diffuse component corresponding to 1.4 molecules of hexane per asymmetric unit was excluded from the crystallographic refinement. ${ }^{b} R_{1}=\sum\left\|F_{0}|-| F_{c}\right\| / \sum\left|F_{0}\right| .{ }^{c} w R_{2}=\left[\sum\left[w\left(F_{0}^{2}-F_{c}^{2}\right)^{2}\right] / \sum\left[w\left(F_{0}^{2}\right)^{2}\right]\right]^{1 / 2}, w=1 /\left[\sigma^{2}\left(F_{0}^{2}\right)+(a P)^{2}+b P\right]$, where $P=\left[\max \left(0\right.\right.$ or $\left.\left.F_{0}^{2}\right)+2\left(F_{c}^{2}\right)\right] / 3$.

the Chemistry Department Instrumentation Center of the University of Wisconsin-Madison, using an anthracene matrix on a Bruker Reflex II TOF mass spectrometer in positive ion mode. The MALDI-TOF data were calibrated relative to a mixed fullerenes standard containing $\mathrm{C}_{60}$ and $\mathrm{C}_{70}$, acquired from a toluene extract of fullerene soot. For the elemental analysis of $\mathbf{8}$, the sample was handled under argon, and the analysis was performed by Canadian Microanalytical Service, Ltd., in Delta, British Columbia, Canada. The remaining elemental analyses were performed by Midwest Microlab, LLC, in Indianapolis, IN. The magnetic susceptibility measurements were performed with the use of an MPMS-XL Quantum Design SQUID magnetometer. This instrument works between 1.8 and $400 \mathrm{~K}$ with applied direct-current (dc) fields ranging from -7 to $7 \mathrm{~T}$. Measurements were performed on polycrystalline samples of $4 \cdot \mathrm{THF}, \mathbf{5}$, and $\mathbf{8} \cdot 1.3 \mathrm{CH}_{2} \mathrm{Cl}_{2}(11.8,14.7$, and $20.0 \mathrm{mg}$, respectively) sealed in a polyethylene bag $(3 \times 0.5 \times 0.02$ $\mathrm{cm})$. Prior to the experiments, the field-dependent magnetization was measured at $100 \mathrm{~K}$ to detect the presence of any bulk ferromagnetic impurities, which have been found to be absent. Alternating current susceptibility measurements were also performed with an oscillating field of 3 Oe with frequencies from 1 to $1500 \mathrm{~Hz}$. No out-of-phase signal was detected above $1.8 \mathrm{~K}$. The magnetic data were corrected for the sample holder and the intrinsic diamagnetic contributions.

2.4. X-ray Structure Determinations at $100 \mathrm{~K}$. Suitable single crystals of $\mathbf{2} \cdot 2.4 \mathrm{THF}, 3 \cdot 0.8 \mathrm{DMSO}, \mathbf{4} \cdot 0.5$ toluene, $4 \cdot \mathrm{THF}, \mathbf{5}, \mathbf{6} \cdot \mathrm{MeCN}$, $8 \cdot 1.3 \mathrm{CH}_{2} \mathrm{Cl}_{2}$ were selected under oil and ambient conditions. The crystals were attached to the tip of a MiTeGen MicroMount and mounted in a stream of cold nitrogen at $100(1) \mathrm{K}$ and centered in the $\mathrm{X}$-ray beam using a video monitoring system. The crystal evaluation and data collection were performed on a Bruker Quazar APEX-II diffractometer with Mo $\mathrm{K} \alpha(\lambda=0.71073 \AA \AA$; 3.0.8DMSO, 4. 0.5 toluene, $5,6 \cdot \mathrm{MeCN}, 8 \cdot 1.3 \mathrm{CH}_{2} \mathrm{Cl}_{2}$, and 9) or a Bruker SMART APEX-II diffractometer with $\mathrm{Cu} \mathrm{K} \alpha(\lambda=1.54178 \AA ̊ 2$ 2 2.4 THF, 4 . THF) radiation. The data were collected using a routine to survey an entire sphere of reciprocal space and were indexed by the SAINT+ program. ${ }^{52}$ The structures were solved via direct methods and refined by iterative cycles of least-squares refinement on $F^{2}$ followed by difference Fourier synthesis using the SHELX2013 suite of programs. ${ }^{53}$ All hydrogen atoms were included in the final structure factor calculation at idealized positions and were allowed to ride on the neighboring atoms with relative isotropic displacement coefficients. The details concerning X-ray crystallographic structure solutions and refinement are given in Table 1 . For each structure, the model was refined to a low $w R_{2}$ value $(<0.15$ for all data in each case).

2.5. Computational Methods. All calculations were performed with the Orca 2.9.1 program package using spin-unrestricted DFT methods. ${ }^{54}$ The triple- $\zeta$ Def-3 (TZV on hydrogen, TZVP on main group atoms, TZVPPP on transition metals) basis set from the Karlsruhe group, ${ }^{55}$ which was recontracted in ORCA for use with the scalar relativistic zeroth-order regular approximation (ZORA), was used for all calculations. Optimizations included an increased integration grid (Grid4) and tight self-consistent field convergence criteria.

Except for compound 4, all geometry optimizations and frequency calculations were performed using the BP8 $6^{56,57}$ functional with the RI approximation $^{58}$ with an appropriate ${ }^{59}$ auxiliary basis. Starting geometries were obtained from their respective crystal structures or from related crystal structures that were edited in Avogadro ${ }^{60}$ to include the correct previously optimized axial ligand at a starting distance of $2.3 \AA$ from the bound ruthenium atom. For compound 4, separate models were generated by geometry optimization using the BP86 functional on crystal coordinates and the TPSS ${ }^{61}$ functional on crystal coordinates. Thermodynamic quantities were generated using the numerical frequency module to correct for zero-point energy and entropy contributions at $298 \mathrm{~K}$.

Single-point energies, molecular orbitals, and electronic transition energies were obtained using the B3LYP ${ }^{62}$ functional and the RIJCOSX approximation ${ }^{63}$ on optimized geometries. Quasi-restricted orbitals (QROs) $)^{64}$ and energies were used. Orbital pictures were plotted using the UCSF Chimera program package. ${ }^{65}$ The electronic structures and properties of the dimeric $\left[\mathrm{Ru}_{2}\right]_{2}$ compounds were optimized in both the high-spin $(S=2)$ and broken-symmetry $(2,2)^{66}$ states. The electronic transition energies were generated using the TDDFT/CIS module ${ }^{67,68}$ with an appropriate COSMO correction ${ }^{69}$ corresponding to the solvent used for the UV-vis spectrum of the compound. To aid comparison to the experimental absorption data, calculated molar absorptivities of electronic transitions were divided by 2 for the $\mathrm{Ru}_{2}$ compounds and by 4 for the $\left[\mathrm{Ru}_{2}\right]_{2}$ compounds.

DFT-calculated binding constants $\left(K_{\mathrm{b}}\right)$ to $\mathrm{Ru}_{2}(\mathrm{chp})_{4}$ for the various axial ligands were determined using the binding energy $(\Delta G)$ through the equation:

$$
K_{\mathrm{b}}=e^{-\Delta G / k_{\mathrm{B}} T}
$$


where $k_{\mathrm{B}}$ is the Boltzmann constant, and the temperature $T$ is assumed to be $298.15 \mathrm{~K}$, except where otherwise noted. The binding energy was determined by subtracting the Gibbs free energy $(G)$ of $\mathrm{Ru}_{2}(\mathrm{chp})_{4}$ and the free ligand (L) from that of the axially ligated species $\mathrm{Ru}_{2}(\mathrm{chp})_{4}(\mathrm{~L}) . G$ for each species was estimated through the thermodynamic equations

$$
\begin{aligned}
& G=H-T S \\
& H=U+k_{\mathrm{B}} T \\
& S=S_{\text {el }}+S_{\text {vib }}+S_{\text {rot }}+S_{\text {trans }}
\end{aligned}
$$

using DFT-optimized values for the inner energy $(U)$, electronic entropy $\left(S_{\mathrm{el}}\right)$, vibrational entropy $\left(S_{\mathrm{vib}}\right)$, and translational entropy $\left(S_{\text {trans }}\right)$. The rotational entropy $\left(S_{\text {rot }}\right)$ was obtained through the equation

$$
S_{\text {rot }}=k_{\mathrm{B}}\left[\ln \left(\frac{q_{\mathrm{rot}}}{\sigma}\right)+N\right]
$$

where $q_{\text {rot }}$ is the DFT-optimized rotational partition function for the molecule, $\sigma$ is its symmetry number, ${ }^{70}$ and $N$ is 1 for linear molecules and 1.5 for nonlinear ones.

\section{RESULTS AND DISCUSSION}

3.1. Synthesis. Reduction of $\mathrm{Ru}_{2}(\mathrm{chp})_{4} \mathrm{Cl}, \mathbf{1}$, results either in an axial adduct $(2-6)$, a dimer $(7,8)$, or products without $\mathrm{Ru}-\mathrm{Ru}$ bonds, depending on which potential axial ligands are present in the reaction mixture (Scheme 2). The adduct 2 was

Scheme 2. Summary of Synthetic Work

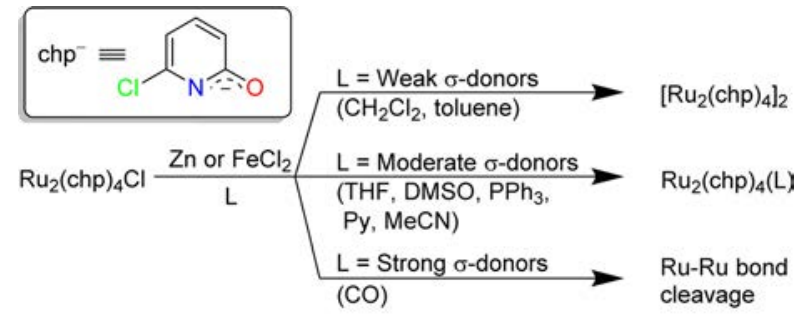

$$
\begin{gathered}
\mathrm{Ru}_{2}(\mathrm{chp})_{4} \mathrm{Cl}+0.5 \mathrm{Zn} \frac{4 \mathrm{hr}, \mathrm{N}_{2}}{\mathrm{THF}} \longrightarrow \mathrm{Ru}_{2}(\mathrm{chp})_{4}(\mathrm{THF})+0.5 \mathrm{ZnCl}_{2} \\
2 \mathrm{Ru}_{2}(\mathrm{chp})_{4}(\mathrm{~L}) \rightleftharpoons\left[\mathrm{Ru}_{2}(\mathrm{chp})_{4}\right]_{2}+2 \mathrm{~L}
\end{gathered}
$$

previously prepared in $93 \%$ yield by Cotton and co-workers through the reduction of $\mathbf{1}$ with excess $\mathrm{Zn}$ dust in a solution of THF (eq 1). ${ }^{45}$ In our hands, the majority of the Ru-containing material under these conditions reproducibly precipitates as the air-stable brown powder 7 prior to filtration, and only a $20 \%$ yield of $\mathbf{2}$ is isolated. Preparing $\mathbf{2}$ in more dilute conditions limited precipitation of 7 but did not increase yields of 2 . The dimer 7 is the exclusive product formed when $\mathrm{Zn}$ reduction is performed in toluene, due to the absence of a sufficiently coordinating axial ligand. Even among moderately coordinating axial ligands, dimerization to 7 can be induced by heat, vacuum, long reaction times, insolubility of the adduct, low concentrations of the axial ligand, or high concentrations of the $\mathrm{Ru}_{2}$ (II,II) species, complicating attempts to isolate axial adducts (eq 2).

Performing the $\mathrm{Zn}$ reduction in $\mathrm{CH}_{2} \mathrm{Cl}_{2}$ at $-10{ }^{\circ} \mathrm{C}$ minimizes premature precipitation of the dimer, so that a dark red filtrate can be separated from the zinc powder. This red solution is sensitive to oxidation in the presence of air, heat, or light, the latter possibly due to photoreduction of the $\mathrm{CH}_{2} \mathrm{Cl}_{2}$ solvent, as has been previously observed in $\mathrm{Rh}_{2}(\mathrm{II}, \mathrm{II})$ systems. ${ }^{71}$ A zinc chloride-bridged dimer $8 \cdot x \mathrm{CH}_{2} \mathrm{Cl}_{2}(x=0.5-$ 1.3) can be precipitated from this solution by adding hexanes at $-78{ }^{\circ} \mathrm{C}$ and warming to room temperature. In contrast to the air-stable 7 , solid 8 oxidizes to a purple $\mathrm{Ru}_{2}$ (II,III) species over $24 \mathrm{~h}$ in air, possibly due to the presence of $\mathrm{Cl}$ atoms.

When $\mathrm{Zn}$ reduction of $\mathbf{1}$ is performed in DMSO and when the filtrate is layered with water, yellow crystals containing the DMSO adduct 3 form within a day but are not stable to water or vacuum, and they could not be isolated in pure form as a solid. ${ }^{51}$ Washing 3 with water and drying in vacuo overnight shifts the equilibrium of eq 2 toward dimerization, giving clean conversion to 7 . However, this equilibrium is readily reversed upon treating 7 with DMSO, creating solvated 3.

Unlike the $\mathrm{Ru}_{2}\left(\mathrm{O}_{2} \mathrm{CR}\right)_{4}$ systems that are readily cleaved by pyridine and $\mathrm{PPh}_{3},{ }^{30} \mathrm{Ru}_{2}(\mathrm{chp})_{4}$ has proven capable of forming stable adducts with these ligands. When the $\mathrm{Zn}$ reduction is performed in toluene or THF with 10 equiv of $\mathrm{PPh}_{3}$, the olivegreen adduct 4 forms in solution, but the resulting crystals of 4 . 0.5 toluene are not easily isolated from the remaining $\mathrm{PPh}_{3}$ and the byproducts $\mathrm{O}=\mathrm{PPh}_{3}$ and $\mathrm{ZnCl}_{2}\left(\mathrm{OPPh}_{3}\right)_{2} \cdot{ }^{72}$ Pure $4 \cdot \mathrm{THF}$ is instead best isolated in $77 \%$ yield from the THF solution, and no cleavage products are detected. The pyridine adduct 5 can also be made by performing the $\mathrm{Zn}$ reduction with 10 equiv of pyridine in THF, but higher yields (up to 61\%) are obtained by performing the reduction in neat pyridine, although yellow, mononuclear Ru-pyridine byproducts are also formed that are detectable by MALDI-MS. Adducts $\mathbf{4}$ and $\mathbf{5}$ are stable against dimerization, and the formation of $\mathbf{7}$ or $\mathbf{8}$ is easily avoided with a 10 -fold excess of either axial ligand. Both $\mathbf{4}$ and 5 are air-stable in the solid form but behave differently in solution. Air-exposed solutions of 5 in $\mathrm{CH}_{2} \mathrm{Cl}_{2}$ or toluene maintain their red-orange color for weeks, as the pyridine remains coordinated and apparently prevents oxidation. However, the $\mathrm{PPh}_{3}$ ligand of 4 appears to be less strongly bound than the pyridine of $\mathbf{5}$, since dissolving 4 in $\mathrm{CH}_{2} \mathrm{Cl}_{2}$ or toluene without excess $\mathrm{PPh}_{3}$ yields a swift color change from green to orange. Even with 10 equiv of $\mathrm{PPh}_{3}$ present in a toluene solution of 4, exposure to air causes a color change from green to yellow to orange over $2 \mathrm{~d}$, indicating a degradation pathway likely made possible by axial ligand dissociation. The higher thermodynamic stability of $\mathbf{5}$ is demonstrated when $\mathrm{PPh}_{3}$, followed by pyridine in a $2: 1$ ratio, is added to a THF solution of 4 , upon which the green solution turns red-orange, indicating conversion from 4 to 5 .

Because $\mathbf{6}$ is not very soluble in acetonitrile, an alternate, acetonitrile-soluble reductant was necessary to crystallize and isolate this compound. Reduction of 1 over $6 \mathrm{~d}$ through the addition of 1 equiv of $\mathrm{FeCl}_{2}$ dissolved in hot $\mathrm{MeCN}$ without stirring generates bright orange crystals of $6 \cdot \mathrm{MeCN}$. However, unlike the $\mathrm{Zn}$ reduction of $\mathbf{1}$ in $\mathrm{MeCN}$, the reaction using $\mathrm{FeCl}_{2}$ as a reductant does not go to completion over the course of a month. The resulting crystals may be mechanically separated from 7 and unreacted 1 . Crystals of $6 \cdot \mathrm{MeCN}$ do not oxidize in the presence of $\mathrm{O}_{2}$, are vacuum-stable, but also hygroscopic and water-soluble, rendering them air-sensitive. The preparation of 6 is notable in that $\mathrm{MeCN}$ was also reported to cleave the $\mathrm{Ru}-$ $\mathrm{Ru}$ bond of $\mathrm{Ru}_{2}\left(\mathrm{O}_{2} \mathrm{CR}\right)_{4}$ compounds, ${ }^{30}$ but we found no evidence for similar reactivity here.

Attempts to generate a carbon monoxide adduct to $\mathrm{Ru}_{2}(\mathrm{chp})_{4}$ are complicated by dimerization to 7 or $\mathbf{8}$ in the presence of $\mathrm{Zn}$. However, when $\mathbf{5}$ is dissolved in a 3:2 mixture of acetone and hexane, the pyridine ligand becomes labile, as evidenced by the solution becoming sensitive to air-oxidation. This method of conferring gas-sensitivity was used under an 
atmosphere of $\mathrm{CO}$ in an attempt to generate a $\mathrm{CO}$ adduct. As in the case of $\mathrm{Ru}_{2}\left(\mathrm{O}_{2} \mathrm{CR}\right)_{4}$ complexes, ${ }^{30}$ the $\mathrm{CO}$ adducts of $\mathrm{Ru}_{2}(\mathrm{chp})_{4}$ are not stable, and only $\mathrm{Ru}-\mathrm{Ru}$ bond-cleaved degradation products are observed. The orange and yellow pyridine-containing products, including $\mathrm{Ru}(\mathrm{chp})_{2}(\mathrm{CO})(\mathrm{py})$ and $\mathrm{Ru}(\mathrm{chp})_{2}(\mathrm{py})_{2}$ (formulas suggested by MALDI-MS) can be washed away with diethyl ether and acetonitrile, leaving behind the colorless, diamagnetic compound ( $\mu$-chp $)_{2}[\mathrm{Ru}-$ $\left.(\mathrm{chp})(\mathrm{CO})_{2}\right]_{2}$ in poor yield.

3.2. X-ray Crystallography. The crystal structure of $\mathbf{2}$. THF has been previously reported, ${ }^{45}$ but we report here a second solvatomorph $(2 \cdot 2.4 \mathrm{THF})$, along with the crystal structures of the new compounds 4-6 and 8. The molecular structures of these compounds are shown in Figures 1-5, and

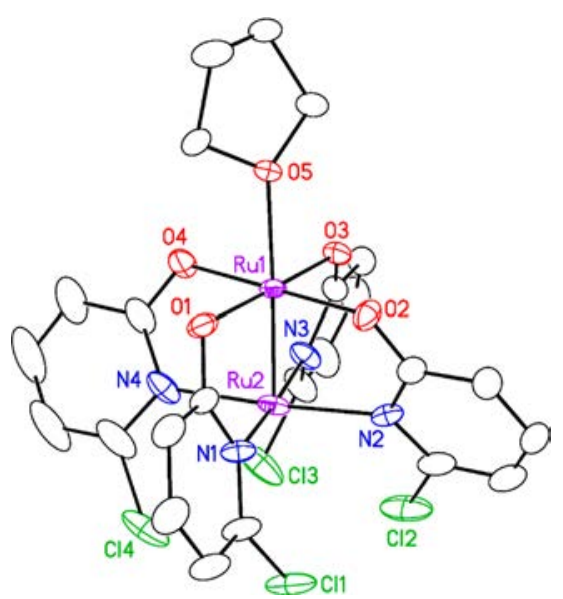

Figure 1. New X-ray crystal structure of the major component of $\mathbf{2}$. All atoms are drawn as $50 \%$ thermal probability ellipsoids, and all $\mathrm{H}$ atoms are omitted for clarity. This crystal structure contained a $44(4) \%$ disordered component to the Ru-bound THF and a total of 2.4 additional unbound THF molecules in the asymmetric unit (not shown).

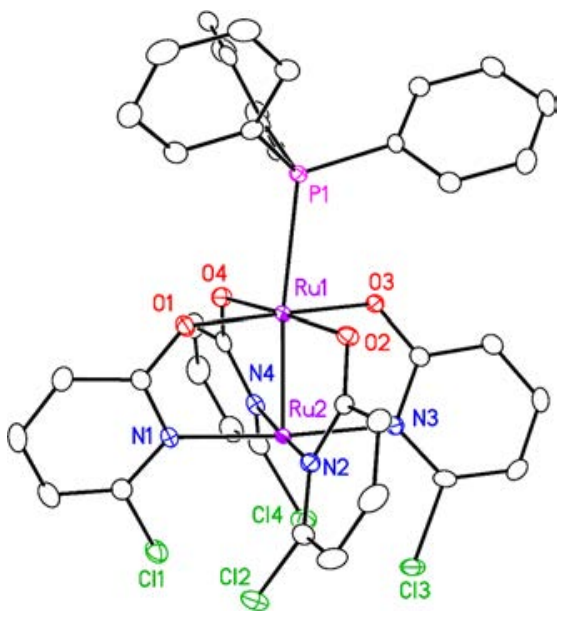

Figure 2. X-ray crystal structure of 4.THF. All atoms are drawn as 50\% thermal probability ellipsoids, and all $\mathrm{H}$ atoms and solvent molecules are omitted for clarity.

selected bond distances, angles, and torsion angles are provided in Table 2. Several X-ray crystal structures containing 3 were obtained, but consistent whole-molecule disorder renders them unreliable, except to determine the shape, connectivity, and $\mathrm{Ru}-\mathrm{Ru}$ distance in the complex. ${ }^{74}$ In each of these compounds,

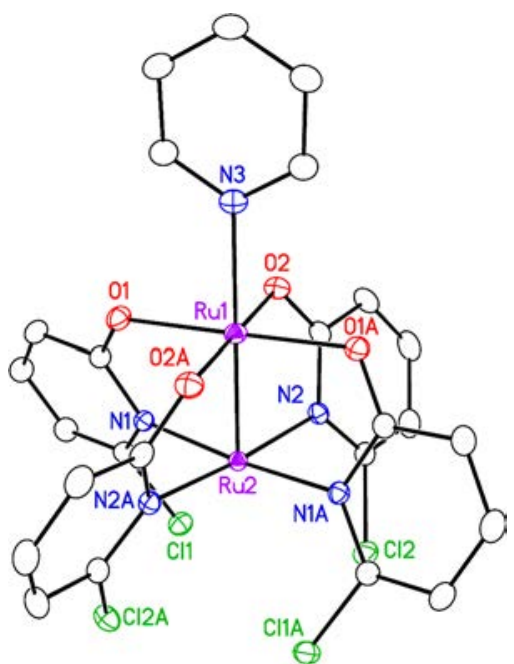

Figure 3. X-ray crystal structure of $\mathbf{5}$. All atoms are drawn as $50 \%$ thermal probability ellipsoids, and all $\mathrm{H}$ atoms are omitted for clarity.

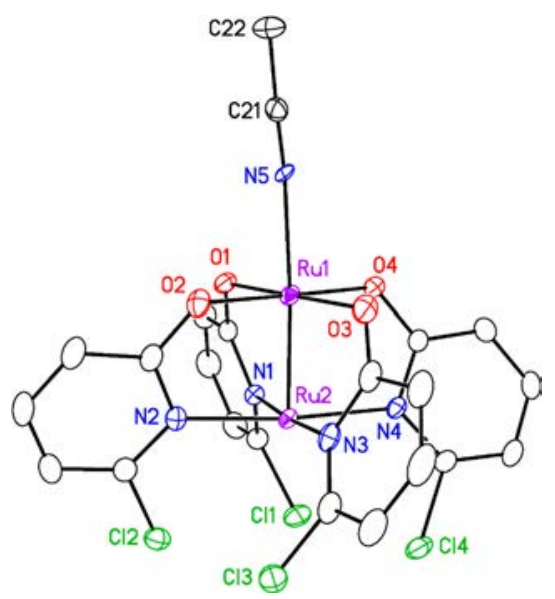

Figure 4. X-ray crystal structure of the major component of 6 . All atoms are drawn as 50\% thermal probability ellipsoids, and all $\mathrm{H}$ atoms are omitted for clarity. 6 crystallized with the axially bound $\mathrm{MeCN}$ disordered across $30.1(3) \%$ and $18.0(3) \%$ minor components, with an axial chloride of 1 occupying the remaining 6.6(2)\% occupancy (not shown). 6 also crystallizes with an additional unbound $\mathrm{MeCN}$ molecule in the asymmetric unit.

the $\mathrm{Ru}_{2}$ paddlewheel-type core adopts the 4,0 arrangement of chp ligands. In this arrangement the chlorine atoms of the chp ligands sterically block one of the axial coordination sites but allow the coordination of a variety of $\mathrm{N}, \mathrm{O}$, and $\mathrm{P}$ donor ligands in the opposite axial position. The crystallographic structure of 2.2.4THF (Figure 1) compares favorably with the previously determined solvatomorph of 2 .THF. The $\mathrm{Ru}-\mathrm{O}_{\mathrm{ax}}, \mathrm{Ru}-\mathrm{O}_{\mathrm{eq}}$, and $\mathrm{Ru}-\mathrm{N}_{\mathrm{eq}}$ bond distances as well as the $\mathrm{Ru}-\mathrm{Ru}-\mathrm{O}_{\text {eq }}$ and $\mathrm{Ru}-\mathrm{Ru}-\mathrm{N}_{\mathrm{eq}}$ angles are statistically identical between the two structures. The main differences between the structures are the $\mathrm{Ru}-\mathrm{Ru}$ bond distance, the $\mathrm{Ru}-\mathrm{Ru}-\mathrm{O}_{\mathrm{ax}}$ bond angle, and the average $\mathrm{N}-\mathrm{Ru}-\mathrm{Ru}-\mathrm{O}_{\text {eq }}$ torsion angle, but none of these differences are large enough to be of any chemical significance.

Among compounds 2-6 and 8, the $\mathrm{Ru}-\mathrm{L}_{\mathrm{eq}}$ bond distances and angles are largely similar. The $\mathrm{Ru}-\mathrm{L}_{\mathrm{eq}}$ bond distance that shows the most variability is the $\mathrm{Ru}-\mathrm{O}_{\mathrm{eq}}$ bond length (range: $2.029[6]-2.0528[8] \AA$ ) . In general, longer $\mathrm{Ru}-\mathrm{O}_{\mathrm{eq}}$ bond distances correlate with shorter $\mathrm{Ru}-\mathrm{Ru}$ bond distances and vice versa. Both of these features correlate roughly with the $\mathrm{N}-\mathrm{Ru}-$ 


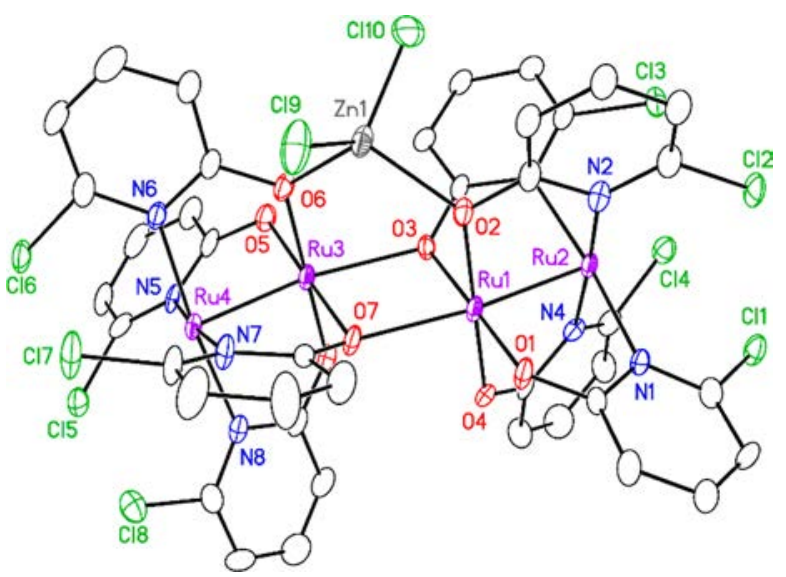

Figure 5. X-ray crystal structure of 8 . All atoms are drawn as $50 \%$ thermal probability ellipsoids, and all $\mathrm{H}$ atoms are omitted for clarity. 8 crystallizes with 1.3 molecules of $\mathrm{CH}_{2} \mathrm{Cl}_{2}$ in the asymmetric unit (not shown).

$\mathrm{Ru}-\mathrm{O}_{\mathrm{eq}}$ torsion angle, in agreement with the observations made by Patmore and co-workers, except in $\mathbf{4}$ and $\mathbf{5}$, which have higher torsion angles than would be expected based on their long $\mathrm{Ru}-\mathrm{Ru}$ distances (Figure 6). ${ }^{75}$

The formal shortness ratio (FSR) of the $\mathrm{Ru}-\mathrm{L}_{\mathrm{ax}}$ bond, calculated as the ratio between the measured bond length and the sum of the single-bond covalent radii of the constituent atoms, ${ }^{76}$ is an indicator of bond multiplicity. ${ }^{1,77}$ Since the donor atoms of the axial ligands differ in 2-6 and 8, the multiplicity of the $\mathrm{Ru}-\mathrm{L}_{\mathrm{ax}}$ bond is inadequate for evaluating the strength of those interactions, but may give some insight into the extent of back-donation from the metal orbitals into the axial ligands. The FSR values for the various adducts in this series suggest that the extent of $\pi$-acceptance by the axial ligand goes in the order of $\mathrm{PPh}_{3}>$ pyridine $\approx \mathrm{MeCN}>\mathrm{Ru}_{2}(\mathrm{chp})_{4} \approx \mathrm{THF}$ (Table 2).

The typical range for the $\mathrm{Ru}-\mathrm{Ru}$ bond distance in paramagnetic $\mathrm{Ru}^{\mathrm{II}}-\mathrm{Ru}{ }^{\mathrm{II}}$ compounds is between 2.24 and 2.28 $\AA$, into which most of our compounds fall. ${ }^{1,6}$ The observed differences indicate the structural trans effect (STE) of each axial ligand, which is associated with ligand basicity. ${ }^{78}$ The trend seen in these compounds shows that the $\mathrm{O}$ donor ligands have the weakest STE, followed by the N-donor and then Pdonor ligands. These differences are not accounted for by the qualitative estimates of basicity suggested by hard/soft acid/ base theory, a fact that is further highlighted by the DMSO complex being found only as the O-bound adduct, and not as the S-bound adduct, which is unusual for $\mathrm{Ru}^{\mathrm{II}}{ }^{79}$ Though the axial ligand binding in 8 (and likely in 7 as well) would be estimated as the weakest metal-ligand bonding interaction through this analysis, the dimers each have two of these $\mathrm{Ru}-$ $\mathrm{O}_{\mathrm{ax}}$ bonds, as shown in Figure 5, accounting for the observation that dimerization acts as a thermodynamic sink in most of the reactions to generate $\mathrm{Ru}_{2}$ (II,II).

To deconvolute $\sigma$ and $\pi$ effects on the observed STE, we can use literature measures of basicity to estimate $\sigma$-donor strength (Table 3). The enthalpy of protonation of each ligand provides a good measure of the $\sigma$-interaction due to electrostatics, ${ }^{80,81}$ while the enthalpy of binding to $\mathrm{BF}_{3}$ takes into account more polarization of the Lewis acid, ${ }^{82}$ and the measure of electron donation to $\mathrm{HgBr}_{2}\left(D_{\mathrm{S}}\right)$ illustrates the effect of a purely softsoft acid-base interaction. ${ }^{83}$ Though MeCN, THF, and DMSO span nearly the entire range of basicity in each of these series,

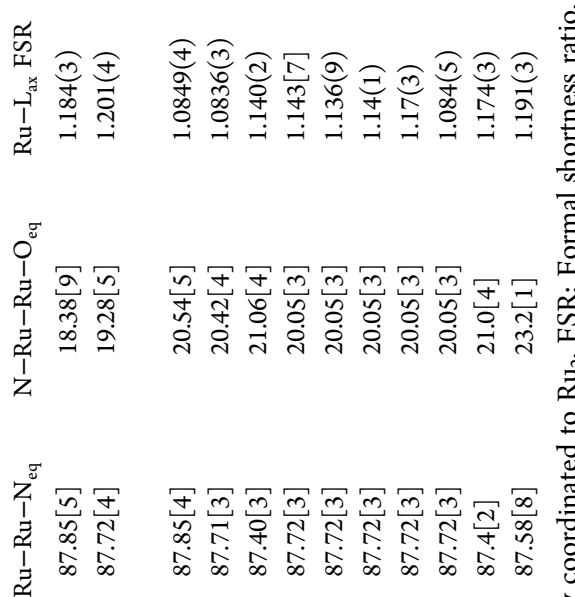

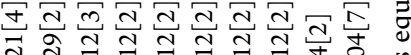
กั

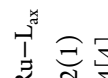

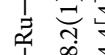$$
\text { 至 }
$$

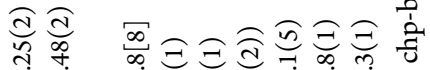

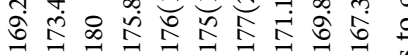

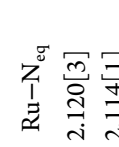

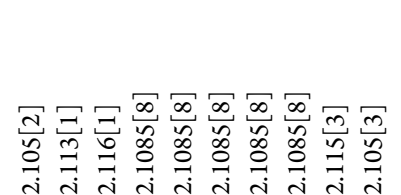$$
\frac{\sqrt{2}}{2}
$$

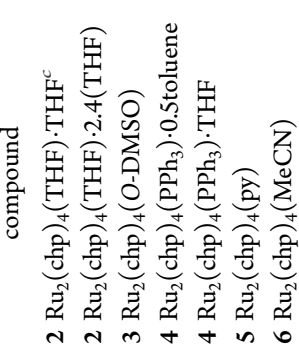




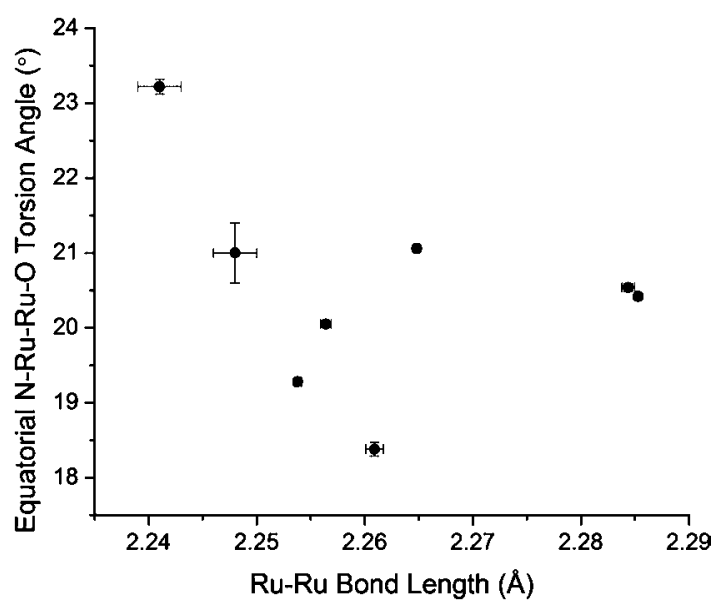

Figure 6. Comparison of equatorial ligand torsion angles and $\mathrm{Ru}-\mathrm{Ru}$ distances in the crystal structures for the various adducts.

Table 3. Basicity of the Axial Ligands of Compounds 2-6

$\begin{array}{llccc}\begin{array}{c}\text { axial } \\ \text { ligand }\end{array} & \begin{array}{c}-\Delta \mathrm{H}_{\mathrm{HP}}{ }^{a} \\ \left(\mathrm{kcal} \mathrm{mol}^{-1}\right)\end{array} & \mathrm{pK}_{\mathrm{a}}{ }^{c} & \begin{array}{c}-\Delta H_{\mathrm{BF} 3}{ }^{d} \\ \left(\mathrm{~kJ} \mathrm{~mol}^{-1}\right)\end{array} & D_{\mathrm{S}}{ }^{e} \\ \mathrm{MeCN} & 13.6 \pm 0.3 & -10.0 & 60.39 \pm 0.46 & 12 \\ \mathrm{THF} & 19.6 \pm 0.2 & -2.02 & 90.40 \pm 0.28 & 17 \\ \mathrm{PPh}_{3} & 21.2 \pm 0.1^{b} & +2.73 & & \\ \text { DMSO } & 28.6 \pm 0.2 & -1.80 & 105.34 \pm 0.36 & 27.5 \\ \text { pyridine } & 38.6 \pm 0.3 & +5.21 & 128.08 \pm 0.50 & 38\end{array}$

${ }^{a}$ Enthalpy of protonation at $25{ }^{\circ} \mathrm{C}$ by a strong acid in an inert solvent. The acid is $\mathrm{HSO}_{3} \mathrm{~F}$, and the solvent is $\mathrm{CCl}_{4}$, except where otherwise noted. ${ }^{80}{ }^{b}$ The acid is $\mathrm{CF}_{3} \mathrm{SO}_{3} \mathrm{H}$, and the solvent is 1,2 dichloroethene. ${ }^{81}{ }^{c}$ Aqueous. ${ }^{d}$ Enthalpy of complexation with $\mathrm{BF}_{3}$ at $25{ }^{\circ} \mathrm{C}$ in $\mathrm{CH}_{2} \mathrm{Cl}_{2} .{ }^{82}{ }^{e}$ Donor strength scale, based on coordination to $\mathrm{HgBr}_{2}{ }^{83}$

they all exhibit a similar apparent trans effect on the $\mathrm{Ru}-\mathrm{Ru}$ bond. The unexpectedly strong basicity of $\mathrm{MeCN}$ in 6 might be explained by $\pi$-backdonation into $\mathrm{MeCN}$ enhancing the electrostatic component of the $\sigma$-interaction. The pyridine ligand's high basicity further increases the STE effect in $\mathbf{5}$.

The $\mathrm{PPh}_{3}$ adduct 4 has some interesting structural characteristics. Though $\mathrm{PPh}_{3}$ is a moderate base and $\sigma$-donor, the $\mathrm{PPh}_{3}$ adduct shown in Figure 2 has, to our knowledge, the longest $\mathrm{Ru}-\mathrm{Ru}$ distance (2.2853(3) and 2.2844(6) $\AA$ ) of any synthesized $\mathrm{Ru}_{2}(\mathrm{II}, \mathrm{II})$ complex with only $(\mathrm{N}, \mathrm{O})$-type equatorial ligands. $\mathrm{PPh}_{3}$ is the strongest $\pi$-acceptor to form a persistent $\mathrm{Ru}_{2}$ adduct in this series, ${ }^{84}$ which might be expected to shorten the $\mathrm{Ru}-\mathrm{Ru}$ distance through the removal of $\pi^{*}$ electron density. Instead, the $\pi$-withdrawing capacity of this ligand appears to cause a change in electronic structure that lengthens the $\mathrm{Ru}-\mathrm{Ru}$ bond beyond that which would be expected from a $\sigma$-based STE (vide infra). In the case of $\mathrm{C} \equiv \mathrm{O}$, which is both an extremely strong $\sigma$-donor and $\pi$-acceptor, ${ }^{85-87}$ the extent of the bonding interaction is so great that the $\mathrm{Ru}-\mathrm{Ru}$ bond is broken, yielding the dinuclear structure shown in Figure S3 (see Table $\mathrm{S} 1$ for selected bond distances and angles). ${ }^{73}$ Complex 4 is also distinct from the other compounds in the series in that its $\mathrm{Ru}-$ $\mathrm{Ru}-\mathrm{L}_{\mathrm{ax}}$ angle is bent $\left(169-173^{\circ}\right)$, deviating significantly from $180^{\circ}$. This feature is preserved across two different solvatomorphs (Figure S2) without any obvious structural constraints that would require a bent angle.

3.3. Electronic Absorption Spectroscopy. The visible spectra of $\mathrm{Ru}_{2}(\mathrm{chp})_{4}$ adducts show four absorption bands of increasing intensity with increasing energy (Figure 7 and Table

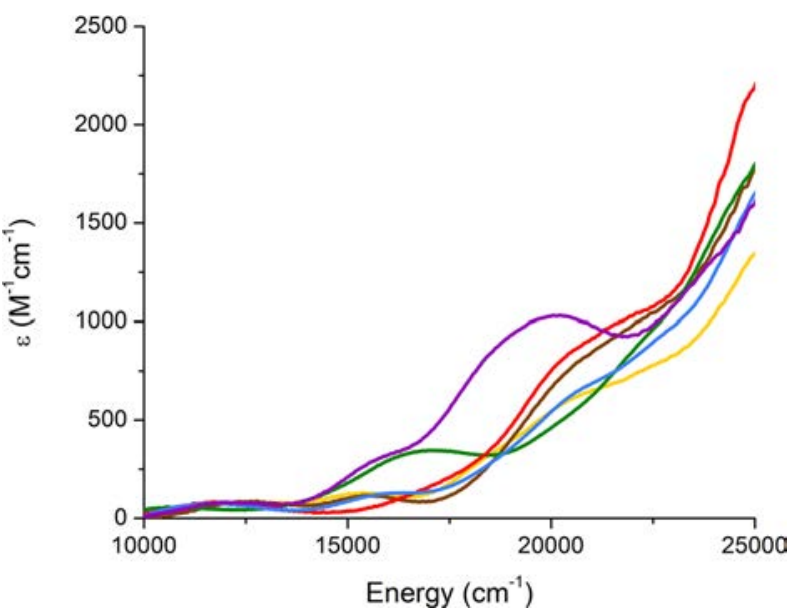

Figure 7. UV-vis spectra for 2 in THF (yellow), 3 in DMSO (brown), 4 in toluene (green), 5 in pyridine (red), 6 in $\mathrm{MeCN}$ (blue), and 8 in $\mathrm{CH}_{2} \mathrm{Cl}_{2}$ (purple).

4). The lowest-energy band, Band 1, has the lowest intensity, with molar absorptivities ranging from $55 \mathrm{M}^{-1} \mathrm{~cm}^{-1}$ for 4 to 84

Table 4. Energies $\left(\mathrm{cm}^{-1}\right)$ of the Major Absorption Bands in the UV-vis Spectra of Compounds 2-6, 8

\begin{tabular}{|c|c|c|c|c|}
\hline compound & solvent & Band 1 & Band 2 & Band 3 \\
\hline $2 \mathrm{Ru}_{2}(\mathrm{chp})_{4}(\mathrm{THF})$ & THF & 12600 & 15400 & $\begin{array}{l}18800,20800, \\
22600\end{array}$ \\
\hline $3 \mathrm{Ru}_{2}(\mathrm{chp})_{4}(\mathrm{DMSO})$ & DMSO & 12600 & 15600 & 20900 \\
\hline $4 \mathrm{Ru}_{2}(\mathrm{chp})_{4}\left(\mathrm{PPh}_{3}\right)$ & toluene & 10800 & 17100 & 22200 \\
\hline $5 \mathrm{Ru}_{2}(\mathrm{chp})_{4}(\mathrm{py})$ & pyridine & 11800 & 17700 & 20900,22100 \\
\hline $6 \mathrm{Ru}_{2}(\mathrm{chp})_{4}(\mathrm{MeCN})$ & $\mathrm{MeCN}$ & 11700 & 16200 & 20900,22900 \\
\hline $8\left[\mathrm{Ru}_{2}(\mathrm{chp})_{4}\right]_{2}\left(\mathrm{ZnCl}_{2}\right)$ & $\mathrm{CH}_{2} \mathrm{Cl}_{2}$ & 12000 & 15800 & 18700,20200 \\
\hline
\end{tabular}

$\mathrm{M}^{-1} \mathrm{~cm}^{-1}$ for 3. The energy of this band appears to correlate with the $\pi$-donor/acceptor character of the axial ligand (Figure S4) and can be assigned as the $\delta \rightarrow \pi^{*}$ transition, as predicted by Miskowski et al. to reside near $12000 \mathrm{~cm}^{-1,6}$ and in agreement with computational results (vide infra). The $\pi$ withdrawing $\mathrm{PPh}_{3}$ ligand gives 4 the lowest-energy Band 1 at $10800 \mathrm{~cm}^{-1}$, followed by the moderately $\pi$-withdrawing $\mathrm{MeCN}$ and pyridine ligands of 6 and 5 at $11700 \mathrm{~cm}^{-1}$ and 11800 $\mathrm{cm}^{-1}$, respectively. The $\pi$-donating THF and DMSO axial ligands of 2 and 3 give the highest-energy Band 1 maxima, both at $12600 \mathrm{~cm}^{-1}$. The red $\mathrm{CH}_{2} \mathrm{Cl}_{2}$ solution of dimer 8 possesses a Band 1 feature at $12000 \mathrm{~cm}^{-1}$. Using this value as a reference point, its proximity to Band 1 for $\mathbf{6}$ and 5 may indicate that $\mathrm{MeCN}$ and pyridine only possess minor $\pi$-withdrawing character as axial ligands to $\mathrm{Ru}_{2}(\mathrm{chp})_{4}$.

Band 2 varies in appearance considerably across the series, with intensities ranging from $110 \mathrm{M}^{-1} \mathrm{~cm}^{-1}$ (3) to $350 \mathrm{M}^{-1}$ $\mathrm{cm}^{-1}$ (4). This band's energy correlates with the $\sigma$-donor strength of the axial ligand (Figure S5). THF and O-DMSO, which had STEs indicative of weak $\sigma$-donor character, put Band 2 for compounds 2 and 3 at $15400 \mathrm{~cm}^{-1}$ and $15600 \mathrm{~cm}^{-1}$, respectively. In accordance with the moderate STE observed for $\mathrm{MeCN}$ and the moderate $\sigma$-donor character expected for $\mathrm{PPh}_{3}$, Band 2 for 6 and 4 are accordingly at the moderate energies of $16200 \mathrm{~cm}^{-1}$ and $17100 \mathrm{~cm}^{-1}$, respectively. Pyridine is the strongest $\sigma$-donor in the series, and thus Band 2 for complex 5 accordingly falls so high in energy $\left(17600 \mathrm{~cm}^{-1}\right)$ that it is mostly obscured as a shoulder to Band 3. Dimer 8 
shows Band 2 as a prominent shoulder at $15800 \mathrm{~cm}^{-1}$, indicating that each axially bound chp oxygen atom acts as a weak-to-moderate sigma donor.

Band 3 typically appears as a shoulder on the tail of the very intense Band 4, which reaches its maximum in the UV range. There is no readily identifiable trend in the energies of Band 3, though its position and prominence relative to Band 2 defines the color of each complex. The spectrum for dimer $\mathbf{8}$ shows the most prominent Band 3, appearing as a distinct peak centered at the relatively low energy of $20200 \mathrm{~cm}^{-1}$. This peak's absorbance in the green range gives dimer $\mathbf{8}$ its deep red color in solution. The pyridine complex 7 has the next most prominent Band 3, with large shoulder features around 20900 $\mathrm{cm}^{-1}$ and $22100 \mathrm{~cm}^{-1}$, giving this compound its red-orange color in solution. Compounds 2, 3, and 6 have less prominent shoulders with Band 3 around 20800-20900 $\mathrm{cm}^{-1}$, giving them their orange to yellow-orange appearances. Complex 4 appears olive-green, because the blue-shifted $\left(22200 \mathrm{~cm}^{-1}\right)$ Band 3 barely absorbs above the tail of Band 4 . The nature of Bands 1-4 will be further discussed in the context of computational results (vide infra).

3.4. Magnetic Susceptibility. Although the ${ }^{3} \mathrm{~A}\left(\delta^{*}\right)^{2}\left(\pi^{*}\right)^{2}$ and the ${ }^{1} \mathrm{~A}\left(\pi^{*}\right)^{4}$ ground states can be readily distinguished on the basis of their $\mathrm{Ru}-\mathrm{Ru}$ distances and their room-temperature magnetic susceptibilities, no $\mathrm{M}_{2} \mathrm{~d}^{6}-\mathrm{d}^{6}$ complex with a ${ }^{3} \mathrm{E}$ $\left(\delta^{*}\right)^{1}\left(\pi^{*}\right)^{3}$ ground state has ever been reported. ${ }^{3} \mathrm{E}$ complexes are predicted to have longer $\mathrm{Ru}-\mathrm{Ru}$ distances than ${ }^{3} \mathrm{~A}$ complexes, and shorter $\mathrm{Ru}-\mathrm{Ru}$ distances than the ${ }^{1} \mathrm{~A}$ complexes, but it is unclear where the dividing lines are that would conclusively distinguish the new ground state from the familiar ones. The two paramagnetic states would have similar room-temperature magnetic moments. However, the orbital angular momentum present in the ${ }^{3} \mathrm{E}\left(\delta^{*}\right)^{1}\left(\pi^{*}\right)^{3}$ state yields a zero-field splitting parameter $D$ that is less than zero, whereas this orbital angular momentum is absent in the ${ }^{3} \mathrm{~A}$ state, making $D>0$. Thus, the two states might be empirically distinguished by their temperature-dependent magnetic susceptibilities. ${ }^{6}$ Even so, it is unlikely that the ideal magnetic behavior of the ${ }^{3} \mathrm{E}$ state could ever be observed in an electronic ground state, because rhombic distortions in a complex will disrupt the $\pi^{*} x / y$ degeneracy and quench the orbital angular momentum, leaving $D>0$.

Compounds $\mathbf{4}$ and $\mathbf{5}$ have the two longest $\mathrm{Ru}-\mathrm{Ru}$ distances of the series reported here, yet the green color and a few odd structural features of $\mathbf{4}$ (vide supra) make it very distinct from 5, which shares the orange color and most of the structural features of the other ${ }^{3} \mathrm{~A}$ complexes. Also of interest is the nature of magnetic coupling in dimer 8. Hence, the magnetic susceptibilities $(\chi)$ of $\mathbf{4}, \mathbf{5}$, and $\mathbf{8}$ were measured between 1.8 and $290 \mathrm{~K}$ (Figure 8). For 4 and 5, the $\chi T$ products at $290 \mathrm{~K}$ are 1.01 and $1.08 \mathrm{~cm}^{3} \mathrm{~K} \mathrm{~mol}^{-1}$, respectively, indicative of an $S=$ 1 system. The $\chi T$ product for both compounds decreases smoothly to reach in both cases $0.01 \mathrm{~cm}^{3} \mathrm{~K} \mathrm{~mol}^{-1}$ at $1.85 \mathrm{~K}$. This thermal behavior is typical of $\mathrm{Ru}_{2}^{4+}$ paddlewheel complexes with a considerable zero-field splitting, suggesting a ${ }^{3} \mathrm{~A}$ ground state for both complexes despite the abnormally long $\mathrm{Ru}-\mathrm{Ru}$ distance in $4{ }^{88}$ The susceptibility data at $1000 \mathrm{Oe}$ were fit to a simple $S=1$ anisotropic spin model based on the Hamiltonian $\hat{H}=g \mu_{\mathrm{B}} H \hat{S}+D S_{z}^{2}$, where $D$ is the uniaxial zerofield splitting parameter and $S=1 .^{89}$ The analytical expression of the average susceptibility is given by the following relation:

$$
\chi=\left(2 M_{x y}+M_{z}\right) / 3 H
$$

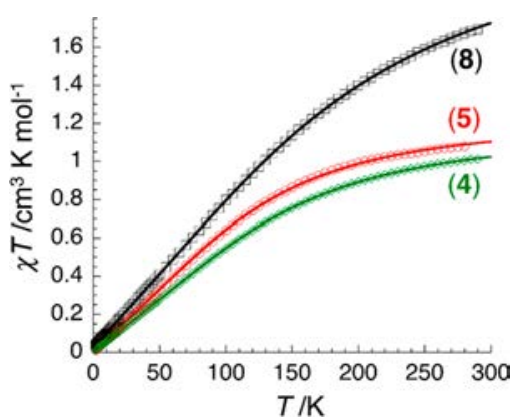

Figure 8. Temperature dependence of the $\chi T$ product for $\mathbf{4}, \mathbf{5}$, and $\mathbf{8}$ at 1000 Oe (with $\chi$ defined as the molar magnetic susceptibility equal to $M / H$ per mole of complex).

with

$$
M_{x y}=\frac{N g \mu_{\mathrm{B}} G}{\sqrt{D^{2} / 4+G^{2}}}\left[\frac{2 \sinh \left(\frac{\sqrt{D^{2} / 4+G^{2}}}{k_{\mathrm{B}} T}\right)}{2 \cosh \left(\frac{\sqrt{D^{2} / 4+G^{2}}}{k_{\mathrm{B}} T}\right)+\exp \left(-\frac{D}{2 k_{\mathrm{B}} T}\right)}\right]
$$

and

$$
M_{z}=N g \mu_{\mathrm{B}}\left[\frac{2 \sinh \left(\frac{G}{k_{\mathrm{B}} T}\right)}{2 \cosh \left(\frac{G}{k_{\mathrm{B}} T}\right)+\exp \left(\frac{D}{k_{\mathrm{B}} T}\right)}\right]
$$

where $\mathrm{G}=g \mu_{\mathrm{B}} H$. The data fitting gives $g_{\mathrm{av}}=2.15(6)$ and $\mathrm{D} / k_{\mathrm{B}}$ $=+417(4) \mathrm{K}$ for 4 and $g_{\mathrm{av}}=2.2(1)$ and $\mathrm{D} / k_{\mathrm{B}}=+366(4) \mathrm{K}$ for 5. In comparison, the $\mathrm{Ru}_{2}{ }^{4+}$ tetra-acetate and tetrabenzoate complexes show similar magnetic behavior, with $g$ values of 2.08 and 2.1 and zero-field splitting parameters of +351 and $+309 \mathrm{~K}$, respectively, ${ }^{90}$ while $g=2.00$ and $D / k_{\mathrm{B}}=+375 \mathrm{~K}$ were found for the one-dimensional system $\left[\mathrm{Ru}_{2}\left(\mathrm{O}_{2} \mathrm{CCF}_{3}\right)_{4}\right.$ $\left.\left(\mathrm{C}_{16} \mathrm{H}_{16}\right)\right] .^{91}$ Similarly, $\mathrm{Ru}_{2}{ }^{4+}$ complexes with aliphatic carboxylates display $g$ values from 2.05 to 2.12 and $D / k_{\mathrm{B}}$ values ranging from +389 to $+452 \mathrm{~K} .{ }^{92}$ However, a small (and suspect $\left.{ }^{93}\right) g$ value of 1.64 was found for $4,0-\mathrm{Ru}_{2}(\mathrm{fhp})_{4}(\mathrm{thf})$, a fluorine analogue of the studied molecules, with a comparable $D / k_{\mathrm{B}}$ value of $+378 \mathrm{~K}^{44}$ Most of the other treatments of the magnetic data of $\mathrm{Ru}_{2}{ }^{4+}$ compounds fix the $g$ value to 2.00. In this way, a series of $\mathrm{Ru}_{2}\left(\mathrm{O}_{2} \mathrm{CAr}\right)_{4}$ compounds, where $\mathrm{Ar}=$ fluorine-substituted phenyl, exhibited $D / k_{\mathrm{B}}$ values ranging from +333 to $+449 \mathrm{~K}^{10}$ the one-dimensional compound $\left[\mathrm{Ru}_{2}\left(\mathrm{O}_{2} \mathrm{CCF}_{3}\right)_{4}(\mathrm{Phz})\right]$ gave $\mathrm{D} / k_{\mathrm{B}}=+399 \mathrm{~K},{ }^{12}$ and the trifluoroactete and perfluorobenzoate (2,2,6,6-tetramethylpiperidin-1-yl)oxidanyl adducts revealed $D / k_{\mathrm{B}}=+338$ and $+350 \mathrm{~K}$, respectively. ${ }^{94}$ Thus, 4 and 5 show magnetic features that are similar to known ${ }^{3} \mathrm{~A}$ compounds.

The magnetic behavior of dimer $\mathbf{8}$ (Figure $8 \mathrm{c}$ ) is qualitatively similar to that of the binuclear compounds, tending toward zero at $1.85 \mathrm{~K}$. However, the $\chi T$ product only reaches $1.69 \mathrm{~cm}^{3} \mathrm{~K}$ $\mathrm{mol}^{-1}$ at $290 \mathrm{~K}$, which is less than the theoretical value for two non-interacting $S=1$ centers $\left(2.0 \mathrm{~cm}^{3} \mathrm{~K} \mathrm{~mol}^{-1}\right)$, suggesting a strong zero-field splitting and/or the additional presence of anti-ferromagnetic coupling between the paddlewheel complexes. Therefore, the fit was performed using eq 3 multiplied by a factor of 2 to take into account the second paddlewheel unit and modified with the potential intercomplex interactions in the frame of the mean field approximation 
Table 5. Selected Bond Lengths (Å) and Angles (deg) for the DFT-Computed Structures of 2-8 and Additional Adducts

\begin{tabular}{|c|c|c|c|c|c|c|c|c|c|}
\hline compound & version & $\mathrm{Ru}-\mathrm{Ru}$ & $\mathrm{Ru}-\mathrm{L}_{\mathrm{ax}}$ & $\mathrm{Ru}-\mathrm{O}_{\mathrm{eq}}$ & $\mathrm{Ru}-\mathrm{N}_{\mathrm{eq}}$ & $\mathrm{Ru}-\mathrm{Ru}-\mathrm{L}_{\mathrm{ax}}$ & $\mathrm{Ru}-\mathrm{Ru}-\mathrm{O}_{\mathrm{eq}}$ & $\mathrm{Ru}-\mathrm{Ru}-\mathrm{N}_{\mathrm{eq}}$ & $\mathrm{N}-\mathrm{Ru}-\mathrm{Ru}-\mathrm{O}_{\mathrm{eq}}$ \\
\hline $\mathrm{Ru}_{2}(\operatorname{chp})_{4}$ & & 2.255 & & 2.022 & 2.117 & & 90.9 & 87.4 & 19.8 \\
\hline $\mathrm{Ru}_{2}(\mathrm{chp})_{4}\left(\mathrm{OH}_{2}\right)$ & & 2.263 & 2.294 & 2.033 & 2.120 & 169.8 & 90.9 & 87.5 & 19.1 \\
\hline $2 \mathrm{Ru}_{2}(\mathrm{chp})_{4}(\mathrm{THF})$ & & 2.267 & 2.212 & 2.038 & 2.117 & 179.9 & 90.5 & 87.8 & 19.4 \\
\hline $8\left[\mathrm{Ru}_{2}(\mathrm{chp})_{4}\right]_{2}\left(\mathrm{ZnCl}_{2}\right)$ & & 2.267 & 2.219 & 2.043 & 2.116 & 168.7 & 90.0 & 87.9 & 20.1 \\
\hline $7\left[\mathrm{Ru}_{2}(\mathrm{chp})_{4}\right]_{2}$ & & 2.273 & 2.226 & 2.037 & 2.115 & 168.4 & 90.2 & 87.9 & 19.0 \\
\hline $3 \mathrm{Ru}_{2}(\mathrm{chp})_{4}(\mathrm{O}-\mathrm{DMSO})$ & & 2.273 & 2.200 & 2.039 & 2.117 & 179.1 & 90.3 & 87.8 & 19.4 \\
\hline $6 \mathrm{Ru}_{2}(\mathrm{chp})_{4}(\mathrm{MeCN})$ & & 2.274 & 2.134 & 2.043 & 2.116 & 179.9 & 90.0 & 88.1 & 19.6 \\
\hline $\mathrm{Ru}_{2}(\mathrm{chp})_{4}\left(\mathrm{NH}_{3}\right)$ & & 2.274 & 2.228 & 2.037 & 2.121 & 177.5 & 90.9 & 87.5 & 18.5 \\
\hline $5 \mathrm{Ru}_{2}(\mathrm{chp})_{4}(\mathrm{py})$ & staggered & 2.278 & 2.182 & 2.041 & 2.118 & 180.0 & 90.2 & 87.9 & 19.4 \\
\hline $5 \mathrm{Ru}_{2}(\mathrm{chp})_{4}(\mathrm{py})$ & eclipsed & 2.279 & 2.197 & 2.042 & 2.116 & 180.0 & 90.0 & 88.0 & 19.4 \\
\hline $\mathrm{Ru}_{2}(\mathrm{chp})_{4}\left(\mathrm{CH}_{2} \mathrm{Cl}_{2}\right)$ & & 2.288 & 2.742 & 2.025 & 2.111 & 176.9 & 90.2 & 87.7 & 18.6 \\
\hline $4 \mathrm{Ru}_{2}(\mathrm{chp})_{4}\left(\mathrm{PPh}_{3}\right)$ & TPSS & 2.295 & 2.556 & 2.039 & 2.110 & 172.9 & 89.1 & 87.8 & 21.0 \\
\hline $\mathrm{Ru}_{2}(\operatorname{chp})_{4}\left(\mathrm{~N}_{2}\right)$ & & 2.349 & 2.074 & 2.015 & 2.100 & 180.0 & 89.6 & 87.6 & 16.6 \\
\hline $\mathrm{Ru}_{2}(\mathrm{chp})_{4}(\mathrm{~S}-\mathrm{DMSO})$ & & 2.363 & 2.464 & 2.014 & 2.100 & 177.6 & 89.4 & 87.4 & 16.2 \\
\hline $\mathrm{Ru}_{2}(\mathrm{chp})_{4}(\mathrm{CO})$ & & 2.391 & 1.954 & 2.022 & 2.099 & 180.0 & 88.7 & 87.4 & 16.6 \\
\hline
\end{tabular}

$$
\chi=(1-\rho) \frac{2 \chi_{\mathrm{Ru}_{2}}}{1-\frac{2 z J}{N g^{2} \mu_{\mathrm{B}}^{2}} \chi_{\mathrm{Ru}_{2}}}+\rho C_{\mathrm{imp}} / T
$$

where $J$ is the magnitude of the inter-paddlewheel interaction and $z=1$. eq 4 also takes into account a small correction for extrinsic paramagnetic impurities $(\rho)$ often detected in compounds with a diamagnetic ground state. ${ }^{95}$ A fit where $g$ was fixed at 2.2 and the other parameters were left free allowed us to determine $D / k_{\mathrm{B}}=+477(4) \mathrm{K}$ and $J / k_{\mathrm{B}}=-53(2) \mathrm{K}$. Because the positive $D$ and the negative $J$ values both result in a diminishing of the $\chi T$ product with lowering temperature, it is not easy to deconvolute accurately the two effects using magnetic susceptibility measurements. If we consider the value of $D / k_{\mathrm{B}}(+366 \mathrm{~K})$ for 5 as the lower limit for these types of $\mathrm{Ru}_{2}{ }^{4+}$ compounds and fix both $D / k_{\mathrm{B}}$ and $g, J / k_{\mathrm{B}}$ refines to $-114(8) \mathrm{K}$, but with worse agreement with the experiment. Therefore, it seems reasonable that $D / k_{\mathrm{B}}$ and $J / k_{\mathrm{B}}$ are probably closer to $+477 \mathrm{~K}$ and $-53 \mathrm{~K}$, respectively, with an uncertainty that is certainly larger than the mathematical estimation given above. Although these values should be taken with caution, they are the same order of magnitude to those previously found (D/ $k_{\mathrm{B}}=+320(11) \mathrm{K}$ and $\left.J / k_{\mathrm{B}}=-35(12) \mathrm{K}\right)$ for the onedimensional $\left[\mathrm{Ru}_{2}\left(\mathrm{O}_{2} \mathrm{CCF}_{3}\right)_{4}\right]$ system, which also polymerizes via $\mathrm{Ru}-\mathrm{O}$ axial bonds to the equatorial ligand of the neighboring $\mathrm{Ru}_{2}$ unit. $^{91}$

3.5. Computational Description of $\mathbf{R u}_{\mathbf{2}}(\mathrm{II}, \mathrm{II})$ Adducts. 3.5.1. Density Functional Theory Optimized Geometries. In addition to compounds 2-8, DFT geometries were predicted for hypothetical "naked" $\mathrm{Ru}_{2}(\mathrm{chp})_{4}$ and its $\mathrm{H}_{2} \mathrm{O}, \mathrm{NH}_{3}, \mathrm{CH}_{2} \mathrm{Cl}_{2}$, $\mathrm{N}_{2}, S$-DMSO, and CO adducts, as shown in Table 5. The nondimeric structures were optimized with the $\mathrm{Ru}_{2}$ unit in both the $S=0$ and $S=1$ states, and an $S=1$ ground state was energetically favored in all cases. Optimization of the dimers in the closed-shell $S=0$ and open-shell $S=2$ states predicts a thermodynamic preference for the open-shell state, but an apparent lack of overlap between the one-electron components of the highest occupied orbitals indicates the need to model the electronic structure of each dimer as a broken symmetry system. Broken symmetry calculations on the $S=2$ geometries for 7 and 8 each gave anti-ferromagnetic coupling with $J / k_{\mathrm{B}}=$ $-15 \mathrm{~K}$ and $J / k_{\mathrm{B}}=-20 \mathrm{~K}$, respectively, ${ }^{96}$ which are the same sign, but both are significantly smaller in magnitude than the experimentally measured value of $J / k_{\mathrm{B}}=-53(2) \mathrm{K}$ for 8 . There is a small, systematic positive error in the $\mathrm{Ru}-\mathrm{Ru}$ distances, but the general trends match those of the experimental crystal structures (Figure S8). The optimized structures can be divided into three categories based on their $\mathrm{Ru}-\mathrm{Ru}$ distances. Category 1 contains compounds with predominantly $\sigma$-donor ligands, giving $\mathrm{Ru}-\mathrm{Ru}$ distances that generally increase with greater $\sigma$ donation from the axial ligand. Category 3 contains compounds with highly $\pi$-withdrawing axial ligands, with longer $\mathrm{Ru}-\mathrm{Ru}$ distances that also generally increase with greater $\sigma$-donation from the axial ligand, ranging from $2.349 \AA$ for $\mathrm{Ru}_{2}(\mathrm{chp})_{4}\left(\mathrm{~N}_{2}\right)$ to $2.391 \AA$ for $\mathrm{Ru}_{2}(\mathrm{chp})_{4}(\mathrm{CO})$. Category 2 contains 4 and the $\mathrm{CH}_{2} \mathrm{Cl}_{2}$ adduct, which both have intermediate $\mathrm{Ru}-\mathrm{Ru}$ distances that do not fit into either Category 1 or 3.

Category 1 contains complexes with short optimized $\mathrm{Ru}-\mathrm{Ru}$ distances, typical of $\mathrm{Ru}_{2}(\mathrm{II}, \mathrm{II})$ in the ${ }^{3} \mathrm{~A}\left(\delta^{*}\right)^{2}\left(\pi^{*}\right)^{2}$ ground state, ${ }^{6}$ ranging from $2.255 \AA$ for $\mathrm{Ru}_{2}(\mathrm{chp})_{4}$ to $2.279 \AA$ for the eclipsed rotamer of $\mathrm{Ru}_{2}(\mathrm{chp})_{4}(\mathrm{py})$. Compared to the available crystal structures, these models generally overestimate the $\mathrm{Ru}-$ $\mathrm{Ru}$ distances by between 0.01 and $0.02 \AA$. There is no crystallographic evidence for a $(4,0)$-oriented $\mathrm{Ru}_{2}(\mathrm{chp})_{4}$ complex without any axial ligand, so the closest comparisons can be made to the previously reported axial ligand-free $(2,2)$ trans- $\mathrm{Ru}_{2}(\mathrm{chp})_{4}$ complex ${ }^{45}$ and to the dimeric structures reported previously ${ }^{48}$ and here. The $(2,2)$-oriented complex, the (3,1)-oriented dimer, and the $(4,0)$-oriented dimer 8 exhibit similarly short $\mathrm{Ru}-\mathrm{Ru}$ distances, at 2.248(1), 2.247[1], and 2.245[2] $\AA$, respectively. The optimized $\mathrm{Ru}-\mathrm{Ru}$ distance for the $C_{4}$-symmetric axially free species $(4,0)-\mathrm{Ru}_{2}(\mathrm{chp})_{4}$ is only $0.011 \AA$ longer than even the smallest of these crystallographic $\mathrm{Ru}-\mathrm{Ru}$ distances. This $\mathrm{Ru}-\mathrm{Ru}$ distance is the smallest of the DFT-optimized series, reflecting the lack of any $\sigma$-donor or $\pi$ acceptor in the axial position. On the basis of the crystallographic distances, the dimeric species would not be expected to have significantly greater $\mathrm{Ru}-\mathrm{Ru}$ distances than the axially free $\mathrm{Ru}_{2}(\mathrm{chp})_{4}$ species, yet the optimized model for dimer $\mathbf{8}$ overestimates the average $\mathrm{Ru}-\mathrm{Ru}$ distance relative to the crystal structure of 8 by $0.022 \AA$, and the overestimation is more severe in the optimized model for dimer 7. Hence, the computational models may be assigning too much $\sigma$-donation to the axially bound oxygen atoms of the dimer structures.

The model for $\mathrm{Ru}_{2}(\mathrm{chp})_{4}\left(\mathrm{OH}_{2}\right)$ has the shortest $\mathrm{Ru}-\mathrm{Ru}$ distance of the axially bound models, with the $\mathrm{H}_{2} \mathrm{O}$ hydrogen atoms an average of $2.428 \AA$ from the equatorial chp oxygen atoms and an average $\mathrm{O}_{\mathrm{H} 2 \mathrm{O}}-\mathrm{H} \cdots \mathrm{O}_{\text {chp }}$ angle of $105.4^{\circ}$. This 
arrangement implies a multicoordinating $\mathrm{H}_{2} \mathrm{O}$, with weak $\sigma$ donation to $\mathrm{Ru}$ from the oxygen, and hydrogen bonding to the chp oxygen atoms. However, this arrangement for the $\mathrm{H}_{2} \mathrm{O}$ adduct likely would not occur in the presence of additional water molecules. Preliminary calculations involving varying numbers of additional $\mathrm{H}_{2} \mathrm{O}$ molecules near the $\mathrm{Ru}_{2}(\mathrm{chp})_{4}$ axial site suggest that the binding orientation of the bound $\mathrm{H}_{2} \mathrm{O}$ molecule and the resulting $\mathrm{Ru}-\mathrm{Ru}$ distance depend heavily on the axial ligand's hydrogen-bonding network. A $\mathrm{Ru}-\mathrm{Ru}$ distance of $2.275 \AA$ and average $\mathrm{H}_{\mathrm{H}_{2} \mathrm{O}(\text { axial })} \cdots \mathrm{O}_{\text {chp }}$ distance of $2.814 \AA$ is observed in a model including four total $\mathrm{H}_{2} \mathrm{O}$ molecules. The model of the complex 2 has a slightly longer $\mathrm{Ru}-\mathrm{Ru}$ distance, indicating that THF is acting as a stronger $\sigma$ donor than $\mathrm{H}_{2} \mathrm{O}$, followed by the complexes of O-bound DMSO, MeCN, and $\mathrm{NH}_{3}$. Though the crystal structure of $\mathbf{6}$ is marred by several different disordered orientations for the axially bound $\mathrm{MeCN}$, with $\mathrm{Ru}-\mathrm{N} \equiv \mathrm{C}$ angles ranging from $172(3)^{\circ}$ in the largest component to $147(5)^{\circ}$ in the smallest, the computational model placed this angle at $179.9^{\circ}$. The significant underestimation $(-0.106 \AA)$ of the $\mathrm{Ru}-\mathrm{N}_{\mathrm{ax}}$ distance, as well as having the $\mathrm{MeCN}$ lone pair pointed directly at the $\mathrm{Ru}$ atom, may enhance $\sigma$-donation in the model and could contribute to the slightly larger overestimation $(0.018 \AA)$ of the $\mathrm{Ru}-\mathrm{Ru}$ distance in $\mathbf{6}$. As pyridine is a classically strong $\sigma$-donor, the longest Category $1 \mathrm{Ru}-\mathrm{Ru}$ distances (2.278 and $2.279 \AA$ ) were observed in the staggered and eclipsed models of $\mathbf{5}$. Even though both rotamers of $\mathbf{5}$ have been observed crystallographically, ${ }^{97}$ the staggered model is calculated to be $7.9 \mathrm{kcal}$ $\mathrm{mol}^{-1}$ lower than the eclipsed model. Hence, the staggered model was used for all further analyses.

Category 2 contains only two complexes: $\mathrm{Ru}_{2}(\mathrm{chp})_{4}$ $\left(\mathrm{CH}_{2} \mathrm{Cl}_{2}\right)$ and the $\mathrm{PPh}_{3}$ adduct (4), both with unusually long $\mathrm{Ru}-\mathrm{Ru}$ distances. There is no crystal structure of the $\mathrm{CH}_{2} \mathrm{Cl}_{2}$ adduct for comparison, but $\mathbf{4}$ was crystallographically characterized in two solvatomorphs. Optimizing the geometry of 4 using the BP86 functional as in the previously described models yields a severely erroneous structure, with a $\mathrm{Ru}-\mathrm{Ru}$ distance $0.078 \AA$ longer than that of $4 \cdot 0.5$ toluene and $0.077 \AA$ longer than that of $\mathbf{4}$. THF, putting this model in Category 3. However, using the superior ${ }^{61}$ meta-GGA functional TPSS to optimize this complex gives a Category 2 model, the geometry of which is in much better agreement with the crystal structures, with an optimized $\mathrm{Ru}-\mathrm{Ru}$ distance of $2.295 \AA$ and an optimized $\mathrm{Ru}-\mathrm{P}$ distance of $2.556 \AA$. Given that the optimized $\mathrm{Ru}-\mathrm{Ru}$ distance in the $\mathrm{CH}_{2} \mathrm{Cl}_{2}$ adduct is $0.033 \AA$ longer than in the optimized $\mathrm{Ru}_{2}(\mathrm{chp})_{4}$ complex without any axial ligand, the $\mathrm{CH}_{2} \mathrm{Cl}_{2}$ axial ligand does seem to induce structural changes in the $\mathrm{Ru}_{2}(\mathrm{chp})_{4}$ unit, despite the exceptionally long optimized $\mathrm{Ru}-\mathrm{Cl}$ distance of $2.742 \AA$ and the expectedly weak $\sigma$-donor strength of the $\mathrm{Cl}$ lone pair. The stronger $\sigma$-donation of the $\mathrm{PPh}_{3}$ ligand relative to the $\mathrm{CH}_{2} \mathrm{Cl}_{2}$ axial ligand is reflected by the longer optimized $\mathrm{Ru}-\mathrm{Ru}$ distance for 4 , but the models for these two complexes also share some common features with each other that distinguish them from the other categories. Notably, the $\mathrm{Ru}-\mathrm{N}_{\mathrm{eq}}$ distances of 2.111 and $2.110 \AA$ are directly between the range of values seen in Categories 1 and 3 , and the $\mathrm{Ru}-\mathrm{Ru}-\mathrm{L}_{\mathrm{ax}}$ angle for both complexes is significantly less than $180^{\circ}$ without any obvious geometric constraint that would provide a reason why this distortion is thermodynamically favored, if only slightly (for 4, $\Delta E=-0.4 \mathrm{kcal} \mathrm{mol}^{-1}$ relative to a constrained linear model).
Category 3 contains complexes with long optimized $\mathrm{Ru}-\mathrm{Ru}$ distances ranging from $2.349 \AA$ for $\mathrm{Ru}_{2}(\mathrm{chp})_{4}\left(\mathrm{~N}_{2}\right)$ to $2.391 \AA$ for $\mathrm{Ru}_{2}(\mathrm{chp})_{4}(\mathrm{CO})$. This distance clearly increases with greater $\sigma$-donation from the axial ligand, as seen in the other categories, but is in the range expected for $\mathrm{Ru}_{2}$ (II,II) complexes with the ${ }^{3} \mathrm{E}\left(\delta^{*}\right)^{1}\left(\pi^{*}\right)^{3}$ ground state. ${ }^{6}$ There do not yet exist any crystal structures of $\mathrm{N}_{2}$, S-bound DMSO, or CO adducts to $\mathrm{Ru}_{2}(\mathrm{chp})_{4}$, but these complexes are placed squarely in Category 3 using either the BP86 or TPSS functional. The TPSS models give slightly lower $\mathrm{Ru}-\mathrm{Ru}$ distance estimates than the BP86 models $(\Delta \mathrm{Ru}-\mathrm{Ru}=-0.005 \AA$ to $-0.010 \AA)$, which may correct for some of the systematic overestimation of this distance typically seen in the BP86 models that we have compared to crystal structures. Hence, the TPSS functional creates models of the $\mathrm{Ru}_{2}(\mathrm{chp})_{4}$ complexes that are more likely to have accurate distances and the correct ground state than the BP86 functional. However, except for the $\mathrm{PPh}_{3}$ adduct, the differences are minor in the context of the complexes discussed here, and the same overall trends can be observed in the models using the two different functionals. So for the sake of comparison, all further analysis of the compounds will be based on their BP86 models, except for complex 4, for which the TPSS model will be used as noted earlier.

For the DFT-optimized $\mathrm{Ru}-\mathrm{L}_{\mathrm{ax}}$ bonds, there is a strong inverse correlation between FSR and Löwdin bond order (Figure S9), which has been noted before in reference to metal-metal bond distances. ${ }^{98}$ The FSR of the various adducts increases as $\mathrm{CO} \ll \mathrm{N}_{2}<\mathrm{S}$-DMSO $\approx \mathrm{PPh}_{3}<\mathrm{MeCN}<$ py $<$ $\mathrm{NH}_{3}<\mathrm{O}-\mathrm{DMSO}<\mathrm{THF} \approx \mathrm{Ru}_{2}(\mathrm{chp})_{4}$ (with or without $\left.\mathrm{ZnCl}_{2}\right)<\mathrm{H}_{2} \mathrm{O}<\mathrm{CH}_{2} \mathrm{Cl}_{2}$. This list is nearly the reverse of the sequence of bond orders, which in most cases reflects the expected relative $\pi$-withdrawing/donating character of the axial ligand. However, this does not hold true for the $\mathrm{CH}_{2} \mathrm{Cl}_{2}$ and $\mathrm{H}_{2} \mathrm{O}$ adducts, which appear at the high extreme of FSR and low extreme of bond order due to their extremely weak $\sigma$ interactions with the metal. The Category 1 complexes all exhibit lower $\mathrm{Ru}-\mathrm{L}_{\mathrm{ax}}$ bond orders than the Category 3 complexes, and the Category 2 complex 4 appears between them.

The optimized $\mathrm{Ru}-\mathrm{Ru}-\mathrm{L}_{\mathrm{ax}}$ angle does not show a clear dependence on the category delineations. Except for $\mathrm{NH}_{3}$, all of the simple ligands (coordinated through a single Lewis-acid interaction at the $\mathrm{Ru}$ center) that coordinate through Period 2 elements $(\mathrm{C}, \mathrm{N}, \mathrm{O})$ have optimized $\mathrm{Ru}-\mathrm{Ru}-\mathrm{L}_{\mathrm{ax}}$ angles within $1^{\circ}$ of $180^{\circ}$. All of the multicoordinate ligands (coordinated through a $\mathrm{Ru}-\mathrm{L}_{\mathrm{ax}}$ interaction, as well as Lewis acid interactions with one or more $\mathrm{O}_{\mathrm{eq}}$ atoms: $\left.\mathrm{Ru}_{2}(\operatorname{chp})_{4}\left(\mathrm{H}_{2} \mathrm{O}\right), 7,8\right)$ have $\mathrm{Ru}-$ $\mathrm{Ru}-\mathrm{L}_{\mathrm{ax}}$ angles between $168^{\circ}$ and $170^{\circ}$, ostensibly to favor axial ligand interactions with the $\mathrm{O}_{\mathrm{eq}}$ atoms. All of the simple ligands that coordinate through Period 3 elements $(\mathrm{P}, \mathrm{S}, \mathrm{Cl}$ ) have significantly bent optimized geometries, with $\mathrm{Ru}-\mathrm{Ru}-\mathrm{L}_{\mathrm{ax}}$ angles between $172^{\circ}$ and $177.6^{\circ}$. The bent structure is likely caused by a Jahn-Teller symmetry-lowering effect, as will be further discussed (vide infra), but may also be related to the increased van der Waals radii of the coordinated atoms and the resulting lengthening of the $\mathrm{Ru}-\mathrm{L}_{\mathrm{ax}}$ bond distance. Notably, both Category 2 complexes clearly exhibit this feature, but a wider variety of examples would be required to establish a relationship between $\mathrm{Ru}-\mathrm{Ru}-\mathrm{L}_{\mathrm{ax}}$ angle and the Category 2 $\mathrm{Ru}-\mathrm{Ru}$ bond distance.

In general, the coordination geometries around the $\mathrm{Ru}$ atoms of $\mathrm{Ru}_{2}(\mathrm{chp})_{4}$ tend to exhibit near- or perfect- $C_{4}$ symmetry in Category 1 , minor distortions toward $C_{s}$ symmetry in Category 
2, and minor equatorial ligand positional adjustments toward $C_{2}$ symmetry in Category 3, as shown in Chart 3. As discussed

\section{Chart 3. Structural Features of the Three Categories of} $\mathrm{Ru}_{2}(\operatorname{chp})_{4} \mathrm{~L}$ Compounds

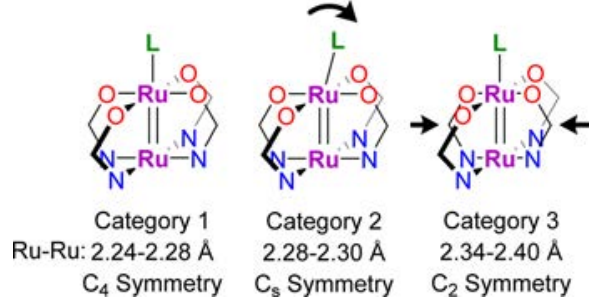

further below, the nature of these distortions may be ascribed to a Jahn-Teller effect. The optimized $\mathrm{Ru}-\mathrm{O}_{\mathrm{eq}}$ distances are generally higher in Category 1 (2.022 to $2.043 \AA$ ) and Category 2 (2.025 to $2.039 \AA)$ than in Category 3 (2.011 to $2.023 \AA$ ). The optimized $\mathrm{Ru}-\mathrm{N}_{\mathrm{eq}}$ distances are highest in Category 1 (2.116 to $2.121 \AA$ ), shorter in Category 2 (2.110 to $2.111 \AA$ ), and shortest in Category 3 (2.098 to $2.100 \AA$ ). Similarly, the optimized $\mathrm{Ru}-\mathrm{Ru}-\mathrm{O}_{\mathrm{eq}}$ angles are generally higher in Category $1\left(90.0^{\circ}\right.$ to $\left.90.9^{\circ}\right)$, intermediate in Category $2\left(89.1^{\circ}\right.$ to $\left.90.2^{\circ}\right)$, and lower in Category $3\left(88.7^{\circ}\right.$ to $\left.89.7^{\circ}\right)$. The $\mathrm{Ru}-\mathrm{Ru}-\mathrm{N}_{\mathrm{eq}}$ angle does not exhibit any clear trend across the categories. The optimized $\mathrm{N}-\mathrm{Ru}-\mathrm{Ru}-\mathrm{O}_{\text {eq }}$ angles are higher in Categories 1 $\left(18.5^{\circ}\right.$ to $\left.20.1^{\circ}\right)$ and $2\left(18.6^{\circ}\right.$ to $\left.21.0^{\circ}\right)$ than in Category 3 $\left(16.2^{\circ}\right.$ to $17.5^{\circ}$; Figure S10). As observed in the crystal structures, the computed torsion angles generally show the same inverse correlation with $\mathrm{Ru}-\mathrm{Ru}$ distance observed by Patmore and co-workers. ${ }^{75}$ The $\mathrm{PPh}_{3}$ adduct 4 is the sole outlier, which may come from a steric effect between the $\mathrm{PPh}_{3}$ aryl rings and the chp oxygen atoms. Though many of these measures vary between categories, as does the $\mathrm{Ru}-\mathrm{Ru}$ distance, none of the distances or angles to the equatorial ligands aside from torsion angle reliably vary with the $\mathrm{Ru}-\mathrm{Ru}$ distance within each category. Hence, it is the unique electronic structure of each category that causes the differences in equatorial ligand position, not just the relative positions of the two metal atoms. Progressing from Category 1 to 2 to 3 , the oxypyridinate ligands squeeze in tighter around the $\mathrm{N}$-bound $\mathrm{Ru}$ atom, while the O-bound $\mathrm{Ru}$ atom is pulled toward its axial ligand.

3.5.2. Electronic Structure. The three different structural categories of $\mathrm{Ru}_{2}(\mathrm{chp})_{4}$ complexes represent three different electronic ground-state configurations. The Category 1 complexes each clearly have a ${ }^{3} \mathrm{~A}$ ground state, with a filled $\delta^{*}$ orbital and two unpaired electrons in the $\pi^{*}$ set of orbitals. The Category 3 complexes each clearly have a ${ }^{3} \mathrm{E}$-derived ground state, with one unpaired electron in the $\delta^{*}$ orbital and three electrons in the $\pi^{*}$ set of orbitals. The Category 2 complexes are structurally intermediate between Categories 1 and 3, yet the magnetic data for complex 4 is similar to those of ${ }^{3} \mathrm{~A}$ compounds. Hence, the Category 2 electronic structure must have the same spin configuration as the ${ }^{3} \mathrm{~A}$ Category 1 complexes but with differences in the orbital structure that enable the intermediate properties.

The energies of the formally metal-based orbitals for the computed complexes are given in the Supporting Information (Table S2). Because many of these complexes optimize to symmetries much lower than $C_{4}$, extensive orbital mixing is allowed, even between orbitals with negligible overlap. This results in situations where, for example, $\mathrm{Ru}_{2} \sigma\left(z^{2}\right)$ character is spread across several different equatorial ligand orbitals. There are even some cases where the $\mathrm{Ru}_{2} \pi$-symmetry and $\delta$ symmetry metal orbitals hybridize with each other. To properly study trends in the axial ligand effects on $\mathrm{Ru}_{2}$ orbitals of different symmetry, the energies of deconvoluted, symmetry-

Table 6. Energies (eV) of the Symmetry-Pure Metal Orbitals for the DFT-Computed Structures of 2-8 and Additional Adducts

\begin{tabular}{|c|c|c|c|c|c|c|c|c|c|}
\hline compound & version & $\sigma\left(z^{2}\right)^{a}$ & $\pi(x z, y z)$ & $\delta(x y)^{a}$ & $\delta^{*}(x y)^{a}$ & $\pi^{*}(x z, y z)^{a}$ & $\sigma^{*}\left(z^{2}\right)$ & $\delta^{*}\left(x^{2}-y^{2}\right)$ & $\delta\left(x^{2}-y^{2}\right)$ \\
\hline $\mathrm{Ru}_{2}(\operatorname{chp})_{4}$ & & -3.291 & $-1.395,-1.394$ & -1.307 & 0 & $0.381,0.381$ & 2.492 & 4.176 & 4.307 \\
\hline $\mathrm{Ru}_{2}(\mathrm{chp})_{4}\left(\mathrm{OH}_{2}\right)$ & & -2.646 & $-1.396,-1.364$ & -1.226 & 0 & $0.521,0.582$ & 3.268 & 4.148 & 4.259 \\
\hline $2 \mathrm{Ru}_{2}(\mathrm{chp})_{4}(\mathrm{THF})$ & & -2.524 & $-1.368,-1.354$ & -1.217 & 0 & $0.543,0.642$ & 3.386 & 4.145 & 4.248 \\
\hline $3 \mathrm{Ru}_{2}(\mathrm{chp})_{4}(O-\mathrm{DMSO})$ & & -2.394 & $-1.351,-1.327$ & -1.189 & 0 & $0.600,0.661$ & 3.365 & 4.096 & 4.241 \\
\hline $6 \mathrm{Ru}_{2}(\mathrm{chp})_{4}(\mathrm{MeCN})$ & & -2.453 & $-1.308,-1.308$ & -1.221 & 0 & $0.473,0.473$ & 3.574 & 4.143 & 4.247 \\
\hline $\mathrm{Ru}_{2}(\mathrm{chp})_{4}\left(\mathrm{NH}_{3}\right)$ & & -2.23 & $-1.387,-1.386$ & -1.232 & 0 & $0.554,0.556$ & 3.579 & 4.11 & 4.246 \\
\hline $5 \mathrm{Ru}_{2}(\mathrm{chp})_{4}(\mathrm{py})$ & & -2.115 & $-1.343,-1.319$ & -1.207 & 0 & $0.541,0.556$ & 3.672 & 4.137 & 4.242 \\
\hline $\mathrm{Ru}_{2}(\mathrm{chp})_{4}\left(\mathrm{CH}_{2} \mathrm{Cl}_{2}\right)$ & & -2.756 & $-1.436,-1.501$ & -1.176 & 0 & $0.349,0.249$ & 2.876 & 4.098 & 4.232 \\
\hline $4 \mathrm{Ru}_{2}(\mathrm{chp})_{4}\left(\mathrm{PPh}_{3}\right)$ & & -2.369 & $-1.254,-1.324$ & -1.138 & 0 & $0.435,0.414$ & 3.268 & 4.111 & 4.226 \\
\hline $\mathrm{Ru}_{2}(\operatorname{chp})_{4}\left(\mathrm{~N}_{2}\right)$ & & -2.519 & $-1.705,-1.871$ & -1.185 & 0 & $-0.166,-0.644$ & 3.209 & 3.736 & 3.958 \\
\hline $\mathrm{Ru}_{2}(\mathrm{chp})_{4}(S$-DMSO $)$ & & -2.54 & $-1.702,-1.893$ & -1.189 & 0 & $-0.088,-0.607$ & 3.025 & 3.687 & 3.979 \\
\hline $\mathrm{Ru}_{2}(\mathrm{chp})_{4}(\mathrm{CO})$ & & -1.999 & $-1.755,-1.739$ & -1.12 & 0 & $-0.341,-0.824$ & 3.415 & 3.731 & 4.001 \\
\hline \multicolumn{10}{|l|}{ Dimers } \\
\hline \multirow[t]{2}{*}{$8\left[\mathrm{Ru}_{2}(\mathrm{chp})_{4}\right]_{2}\left(\mathrm{ZnCl}_{2}\right)$} & $\underset{u}{\text { high-spin }}(g$ & $\begin{array}{l}-2.513 \\
-2.429\end{array}$ & $\begin{array}{c}-1.325,-1.138 \\
-1.310,-1.193\end{array}$ & $\begin{array}{l}-1.068 \\
-1.089\end{array}$ & $\begin{array}{c}-0.015 \\
0.015\end{array}$ & $\begin{array}{c}0.510,0.718 \\
0.747,0.639\end{array}$ & $\begin{array}{l}3.488 \\
3.344\end{array}$ & $\begin{array}{r}4.245 \\
4.212\end{array}$ & $\begin{array}{r}4.440 \\
4.359\end{array}$ \\
\hline & $\begin{array}{l}\text { broken-sym } \\
\quad(\text { units } 1,2)^{d}\end{array}$ & $\begin{array}{l}-2.300 \\
-2.535\end{array}$ & $\begin{array}{c}-1.172,-1.003 \\
-2.763,-2.464\end{array}$ & $\begin{array}{l}-0.918 \\
-1.220\end{array}$ & $\begin{array}{l}0.130 \\
-0.162\end{array}$ & $0.854^{c}$ & $\begin{array}{l}3.578 \\
4.043\end{array}$ & $\begin{array}{r}3.918 \\
4.676\end{array}$ & $\begin{array}{r}4.614 \\
4.867\end{array}$ \\
\hline \multirow[t]{2}{*}{$7\left[\mathrm{Ru}_{2}(\mathrm{chp})_{4}\right]_{2}$} & $\begin{array}{l}\text { high-spin }(g, \\
u)^{b}\end{array}$ & $\begin{array}{l}-2.602 \\
-2.474\end{array}$ & $\begin{array}{r}-1.393,-1.711 \\
-1.396,-1.835\end{array}$ & $\begin{array}{c}-1.180,- \\
1.197\end{array}$ & $\begin{array}{c}-0.002 \\
0.001\end{array}$ & $\begin{array}{r}0.425,0.653 \\
0.634,0.578\end{array}$ & $\begin{array}{l}3.417 \\
3.224\end{array}$ & $\begin{array}{l}4.156 \\
4.190\end{array}$ & $\begin{array}{l}4.324 \\
4.340\end{array}$ \\
\hline & $\begin{array}{l}\text { broken-sym } \\
\quad(\text { units } 1,2)^{d}\end{array}$ & $\begin{array}{l}-2.379 \\
-2.601\end{array}$ & $\begin{array}{l}-1.222,-1.064 \\
-1.500\end{array}$ & $\begin{array}{r}-1.021 \\
-1.337\end{array}$ & $\begin{array}{l}0.139 \\
-0.160\end{array}$ & $0.777^{c}$ & $\begin{array}{l}3.459, \\
3.912\end{array}$ & $\begin{array}{l}4.353 \\
4.569\end{array}$ & $\begin{array}{l}4.448 \\
4.660\end{array}$ \\
\hline
\end{tabular}

${ }^{a}$ Energies of assigned symmetry-pure orbitals are calculated by taking the weighted average of the energies of all orbitals containing $>2 \%$ of the assigned orbital character. Energies are defined relative to the symmetry-pure $\delta^{*}$ orbital. ${ }^{b}$ Because of the non-overlap of spin-up and spin-down components, the weighted average of the energies of all occupied and unoccupied one-electron orbitals is reported here, instead of two-electron quasi-restricted orbital energies. ${ }^{c} g$ and $u$ refer to the gerade and ungerade orbital combinations of the dimer. ${ }^{d}$ Here, the two energies are associated with each $\mathrm{Ru}_{2}$ unit (i.e., unit 1 and unit 2 , respectively). 
pure $\mathrm{Ru}_{2} \sigma\left(z^{2}\right), \delta(x y), \delta^{*}(x y)$, and $\pi^{*}(x z, y z)$ orbitals are needed that can be compared across the series of complexes. Delgado-Jaime and DeBeer suggest an empirically supported method for estimating such energies, $E$, of orthonormal, atomic-derived orbitals based on their Löwdin fractional contributions, $c_{i}$, to several molecular orbitals of known energies, $E_{i}:{ }^{99}$

$$
\langle E\rangle=\frac{\sum_{i} c_{i} E_{i}}{\sum_{i} c_{i}}
$$

The "symmetry-pure" $\mathrm{Ru}_{2}$ orbital energies as derived from eq 5 are given in Table 6, where they are referenced in each case to the energy of the $\delta^{*}$ level, ${ }^{100}$ and more details regarding their derivation are provided in the Supporting Information (Table S3). The $\sigma\left(z^{2}\right) \mathrm{Ru}_{2}$ orbital is, as expected, bonding between the two metal atoms and antibonding to the axial ligand, as can be seen in Figure 9. As the axial ligand becomes more $\sigma$-donating,

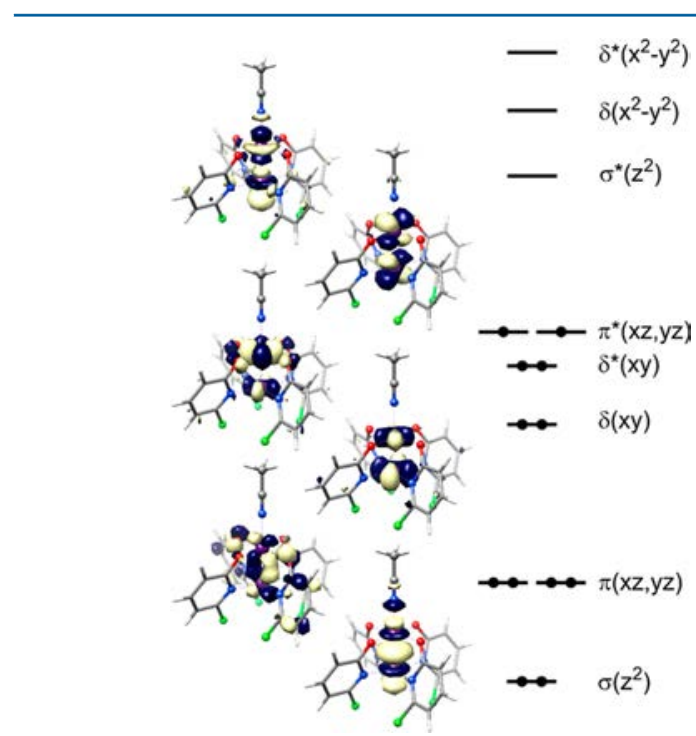

Figure 9. DFT-computed MOs for 6.

this orbital should rise in energy. Also, within each of the three previously defined categories, the energy of this orbital should rise with the $\mathrm{Ru}-\mathrm{Ru}$ distance, as a greater $\sigma$-based trans effect pushes the metals apart. This trend is fairly reliable in the Category 1 complexes, with the energy of $\sigma\left(z^{2}\right)$ ranging from $-3.291 \mathrm{eV}$ in the complex with no axial ligand to $-2.115 \mathrm{eV}$ in the pyridine adduct. One small exception to this trend is the MeCN adduct, which has a $\sigma\left(z^{2}\right)$ orbital $0.059 \mathrm{eV}$ lower in energy than that of the O-bound DMSO complex, despite the two complexes having very similar predicted $\mathrm{Ru}-\mathrm{Ru}$ distances. In the dimeric complexes, the broken-symmetry model increases the energies of the $\sigma\left(z^{2}\right)$ orbitals higher than in the high-spin model, by $0.048 \mathrm{eV}$ for 7 and $0.054 \mathrm{eV}$ for 8, giving averaged energies of -2.490 and $-2.418 \mathrm{eV}$, respectively. Hence, the model for the simple dimer has greater $\sigma$-donation to the metals than the THF adduct, and binding $\mathrm{ZnCl}_{2}$ to the oxypyridinate ligands appears to increase $\sigma$-donation even further. If this were a real effect, then the resulting trans effect would cause the empirical $\mathrm{Ru}-\mathrm{Ru}$ distances in 8 to be significantly longer than in $\mathbf{2}$, but the opposite is observed. This error may result from the overestimated computational $\mathrm{Ru}-\mathrm{Ru}$ distances, which came from the high-spin model. It might be possible to obtain better ab initio models of the dimeric species if exchange coupling between the two units could be accounted for during the geometry-optimization process. In Category 2, the $\mathrm{CH}_{2} \mathrm{Cl}_{2}$ adduct has a $\sigma\left(z^{2}\right)$ energy indicative of the weakest $\sigma$-donation of the series, while the $\mathrm{PPh}_{3}$ of 4 appears to have moderate $\sigma$-donation character, between O-bound DMSO and $\mathrm{NH}_{3}$. Though the sulfur of DMSO has a large van der Waals radius and is classified as a "soft" base like phosphorus, S-bound DMSO has the lowest-energy $\sigma\left(z^{2}\right)$ orbital of Category 3, placing this ligand between $\mathrm{H}_{2} \mathrm{O}$ and THF in $\sigma$-donating character. Even $\mathrm{N}_{2}$ shows greater $\sigma$-donation to $\mathrm{Ru}_{2}$, with a $\sigma\left(z^{2}\right)$ energy comparable to THF. The CO adduct $\sigma\left(z^{2}\right)$ orbital is $0.116 \mathrm{eV}$ higher in energy than that of the pyridine adduct, making $\mathrm{CO}$, as expected, the top $\sigma$-donating ligand of the series.

The calculated $\delta-\delta^{*}$ gap of 1.1 to $1.3 \mathrm{eV}$ reported here is comparable to the $1 \mathrm{eV}$ gap for $\mathrm{Ru}_{2}\left(\mathrm{O}_{2} \mathrm{CH}\right)_{4}$ previously calculated using extended Hückel methods, ${ }^{101}$ and is significantly smaller than the $2 \mathrm{eV}$ gap for $\mathrm{Ru}_{2}(\mathrm{HNNNH})_{4}$ previously calculated using $\mathrm{X} \alpha$-SW methods. ${ }^{46}$ Based on angular overlap, the $\delta(\mathrm{xy})$ and $\delta^{*}(\mathrm{xy})$ orbitals should split apart in energy more as the metals move closer together. This provides an explanation for why the $\delta$ (xy) orbital is at its lowest energy in the axially free species, and at its highest in Categories 2 and 3 . Additionally, the reduced axial symmetry in complexes with bent $\mathrm{Ru}-\mathrm{Ru}-\mathrm{L}_{\mathrm{ax}}$ angles allows mixing of this orbital into the $\pi$ orbitals, pushing the $\delta(x y)$ orbital energy even higher. The extent of this mixing is large enough in the Category 2 complexes that it can be clearly seen as a tilt in the $\delta(x y)$ orbitals (Figure 10). This effect is at least partially corrected for in the analysis by determining the energies of the "symmetrypure" orbitals of Table 6 .

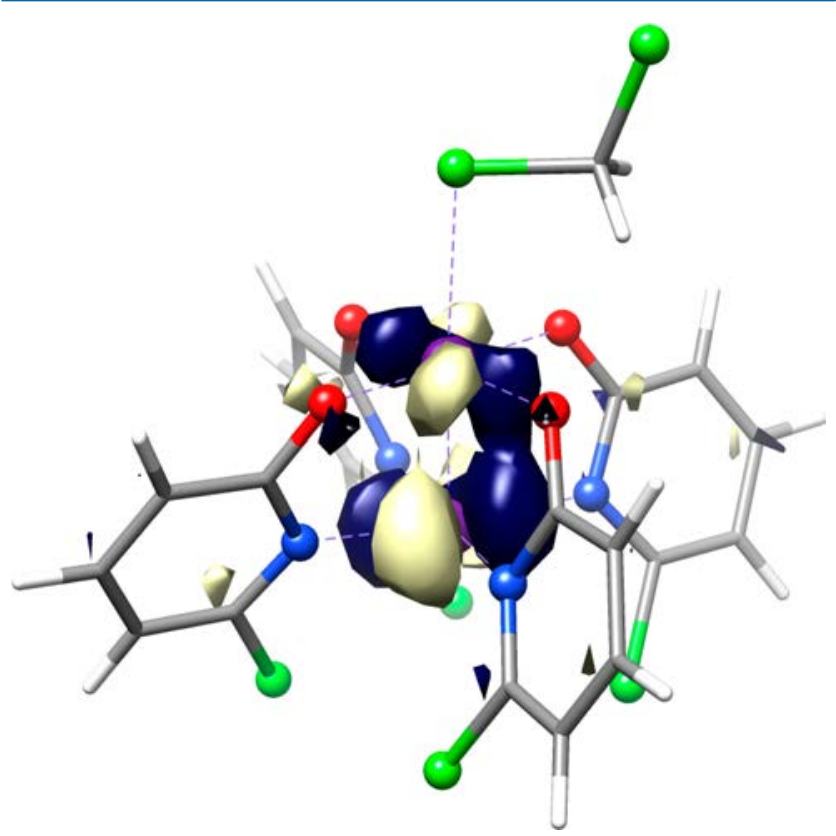

Figure 10. DFT-computed $\delta(x y)$ orbital for $\mathrm{Ru}_{2}(\mathrm{chp})_{4}\left(\mathrm{CH}_{2} \mathrm{Cl}_{2}\right)$.

The $\pi^{*}$ orbitals move up or down in energy based mainly on how $\pi$-donating or $\pi$-withdrawing the axial ligand is, overshadowing the effect from differing $\mathrm{Ru}-\mathrm{Ru}$ distances. Though the $\pi^{*}$ orbital energy of the axially free $\mathrm{Ru}_{2}(\mathrm{chp})_{4}$ complex should ideally lie between that of the compounds of $\pi$-donating and $\pi$-withdrawing axial ligands, its energy value of $0.381 \mathrm{eV}$ relative to the $\delta^{*}(\mathrm{xy})$ orbital is actually lower than that of all of 
the Category 1 complexes due to the lower coordination number. Aside from the axially free species, $\mathrm{MeCN}$ gives the lowest $\pi^{*}$ energy of Category 1 through its $\pi$-withdrawing character, and O-bound DMSO and the dimers give the highest $\pi^{*}$ energy of the series through $\pi$-donation, matching the spectroscopic results. The THF and $\mathrm{H}_{2} \mathrm{O}$ adducts also each show evidence of $\pi$-donation along one axis, while the $\mathrm{NH}_{3}$ and pyridine adducts show little evidence of $\pi$ interaction at all, giving an estimate of the unperturbed $\pi^{*} / \delta^{*}$ splitting for $\mathrm{Ru}_{2}(\mathrm{chp})_{4}(\mathrm{~L})$ complexes of $\Delta \approx 0.55 \mathrm{eV}$. This is comparable to the value of $\Delta \approx 0.41-0.45 \mathrm{eV}$ calculated for $\mathrm{Ru}_{2}\left(\mathrm{O}_{2} \mathrm{CH}\right)_{4}$ using semiempirical methods, ${ }^{101}$ and is significantly more positive than the value of $\Delta \approx-1 \mathrm{eV}$ calculated for $\mathrm{Ru}_{2}(\mathrm{HNNNH})_{4}$ using $\mathrm{X} \alpha$-SW methods. ${ }^{46}$

In Category 3 , the axial $\pi$-withdrawing character is so strong that the $\pi^{*}$ orbitals move below the $\delta^{*}(\mathrm{xy})$ orbital, giving a ${ }^{3} \mathrm{E}\left(\pi^{*}\right)^{3}\left(\delta^{*}\right)^{1}$ ground state. Because the two $\pi^{*}$ orbitals are unequally occupied, a Jahn-Teller distortion occurs in the $\mathrm{Ru}-$ $\mathrm{O}_{\mathrm{eq}}$ and $\mathrm{Ru}-\mathrm{N}_{\mathrm{eq}}$ distances, making the coordination geometry $\mathrm{C}_{2}$-symmetric. This distortion breaks the $\pi^{*}$ degeneracy, putting the singly occupied $\pi^{*}$ orbital approximately $0.5 \mathrm{eV}$ higher in energy than the doubly occupied $\pi^{*}$ orbital. Having a third electron in the $\pi^{*}$ orbitals rather than two in the $\delta^{*}$ orbital results in a longer $\mathrm{Ru}-\mathrm{Ru}$ distance, accounting for many of the structural differences between Category 1 and 3 complexes.

The Category 2 complexes are intermediate between categories 1 and 3 in $\pi$-withdrawing character, due to backdonation into empty $\mathrm{P}-\mathrm{C}$ and $\mathrm{Cl}-\mathrm{C} \sigma^{*}$ orbitals in the $\mathrm{PPh}_{3}$ and $\mathrm{CH}_{2} \mathrm{Cl}_{2}$ complexes, respectively. The $\pi^{*}$ orbitals in both of the Category 2 complexes show clear signs of mixing with the $\delta^{*}(\mathrm{xy})$ orbital (Figure 11), causing severe tilting in the $\delta^{*}(\mathrm{xy})$ orbital, as well as some tilting in $\pi^{*}(\mathrm{xz})$ (perpendicular to the $\mathrm{Ru}-\mathrm{Ru}-\mathrm{L}_{\mathrm{ax}}$ bend), and bulging out to one side in $\pi^{*}(\mathrm{yz})$ (parallel to the $\mathrm{Ru}-\mathrm{Ru}-\mathrm{L}_{\mathrm{ax}}$ bend). Though the $\mathrm{Ru}-\mathrm{Ru}-\mathrm{L}_{\mathrm{ax}}$ bend (and lack of rotational symmetry in the $\mathrm{CH}_{2} \mathrm{Cl}_{2}$ ligand) causes the symmetry-pure $\pi^{*}(\mathrm{xz})$ and $\pi^{*}(\mathrm{yz})$ orbitals to lose degeneracy, mixing with the $\delta^{*}(\mathrm{xy})$ orbital restores that degeneracy in the $\pi^{*}$-originated orbitals. The hybridization necessarily takes some of the spin-density from the $\pi^{*}$ orbitals and places it in the $\delta^{*}$ orbitals, as in the ${ }^{3} \mathrm{E}$ state. By tracking the spin population in the $\delta^{*}$ orbital as a function of the $\mathrm{Ru}-$ $\mathrm{Ru}$ distance (Figure 12), we see a clear delineation between the ${ }^{3} \mathrm{~A}$ Category 1 and ${ }^{3} \mathrm{E}$ Category 3 compounds, as well as a potential continuum between these two states that is thus far only represented by the two Category 2 examples, and potentially the Category 3 complex $\mathrm{Ru}_{2}(\mathrm{chp})_{4}(\mathrm{~S}$-DMSO), which also shows a small degree of $\pi^{*} / \delta^{*}$ hybridization (Table S3). This continuum may be considered to arise from a pseudoJahn-Teller distortion that avoids crossing of either the $\pi^{*}$ and $\delta^{*}$ levels (Chart 4), or the ${ }^{3} \mathrm{~A}$ and ${ }^{3} \mathrm{E}$ states. ${ }^{102}$ The $\mathrm{Ru}-\mathrm{Ru}-\mathrm{L}_{\mathrm{ax}}$ bend distorts the complex to $C_{s}$ symmetry, in which both states transform as ${ }^{3} \mathrm{~A}^{\prime \prime}$, allowing a smooth transition between the $\left(\mathrm{C}_{4}\right.$ symmetry) ${ }^{3} \mathrm{~A}$ and ${ }^{3} \mathrm{E}$-derived ground states through mixing. The ${ }^{3} \mathrm{~A}^{\prime \prime}$ ground state does not allow for the type of orbital angular momentum present in the ${ }^{3} \mathrm{E}$ state, and so, as observed with compound 4 , cannot be distinguished from the ${ }^{3} \mathrm{~A}$ ground state on the basis of temperature-dependent magnetic susceptibility. Further examples of complexes intermediate between the ${ }^{3} \mathrm{~A}$ and ${ }^{3} \mathrm{E}$ states could be deliberately targeted using axial ligands with moderate $\pi$-withdrawing character.

Though prior literature ${ }^{30,103}$ has suggested that $\pi$-withdrawing character from the axial ligand is responsible for the

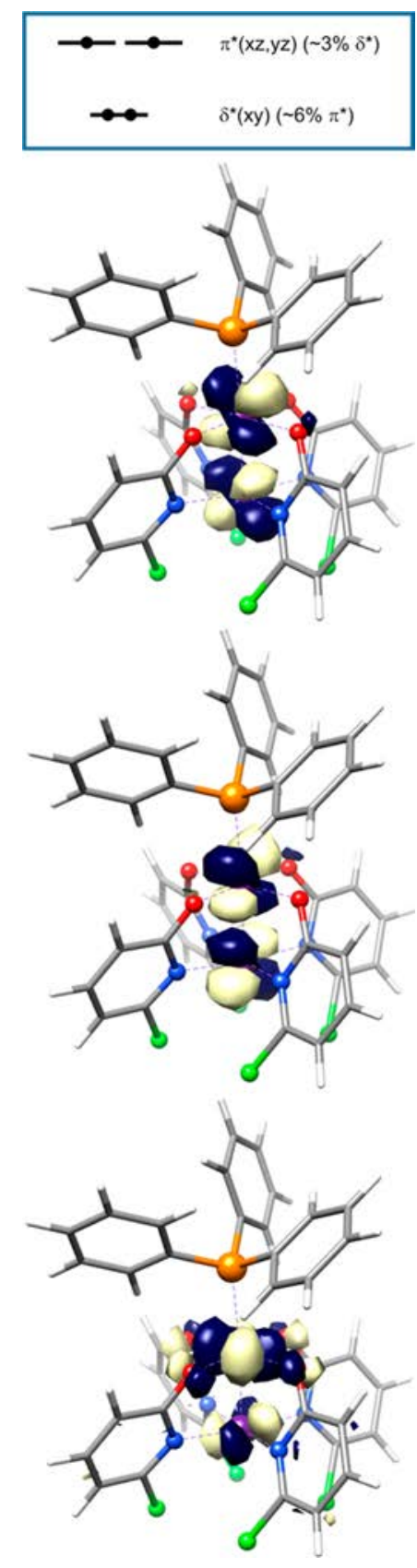

Figure 11. DFT-computed $\pi^{*} / \delta^{*}$ hybrid orbitals for 4 .

$\mathrm{Ru}-\mathrm{Ru}$ cleavage observed in $\mathrm{CO}$, pyridine, and occasionally $\mathrm{PPh}_{3}$ and MeCN adducts, this hypothesis is not supported by the data presented here. The $\mathrm{CO}$ and pyridine adducts are the only members of the $\mathrm{Ru}_{2}(\mathrm{chp})_{4}$ adduct series that show at least partial $\mathrm{Ru}-\mathrm{Ru}$ cleavage in solution, but only one of these ligands is strongly $\pi$-withdrawing. Furthermore, the $\pi$-withdrawing $\mathrm{PPh}_{3}$ ligand forms a complex that is quite stable. Instead, we propose that the $\sigma$-donation of the axial ligand may be responsible for this type of instability in $\mathrm{Ru}_{2}$ complexes with $\mathrm{O}, \mathrm{O}$ - or $\mathrm{N}, \mathrm{O}$-donor equatorial ligands, as both $\mathrm{Ru}-\mathrm{Ru}$-cleaving adducts reported here are due to ligands at the high end of the $\sigma$-donation spectrum. As the $\sigma\left(\mathrm{z}^{2}\right)$ orbital moves higher in energy due to increased antibonding character from the axial ligand, it becomes energetically favorable to $\operatorname{mix} \sigma^{*}\left(\mathrm{z}^{2}\right)$ character into this orbital, polarizing the orbital away from the axial ligand. Toward the extreme of $\sigma$-donation, the $\sigma\left(\mathrm{z}^{2}\right)$ 


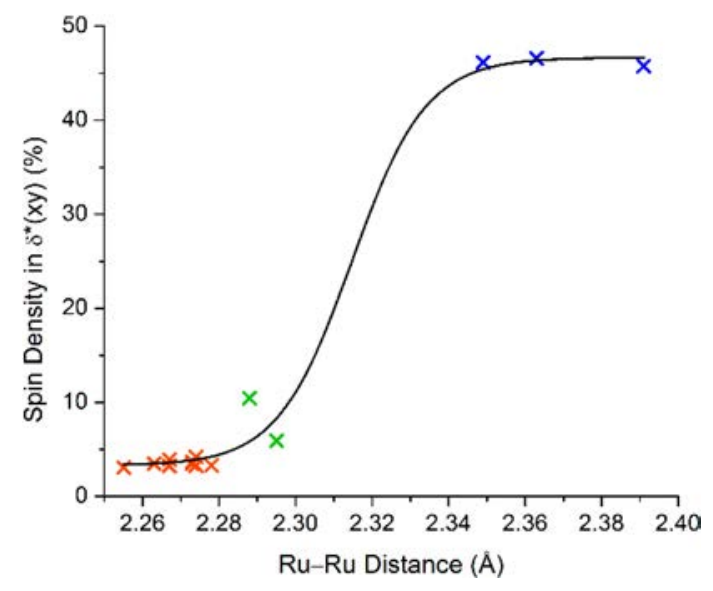

Figure 12. DFT-calculated Loewdin spin densities in the $\delta^{*}(\mathrm{xy})$ orbital, plotted against the DFT-optimized $\mathrm{Ru}-\mathrm{Ru}$ distances, for Category 1 (orange), Category 2 (green), and Category 3 (blue). A sigmoid fit is overlaid.

Chart 4. Dependence of the Relative Energies of the $\delta^{*}$ and Two $\pi^{*}$ Orbitals on the $\pi$-Acceptance of the Axial Ligand at the Transition between ${ }^{3} \mathrm{~A}$ and ${ }^{3} \mathrm{E}$

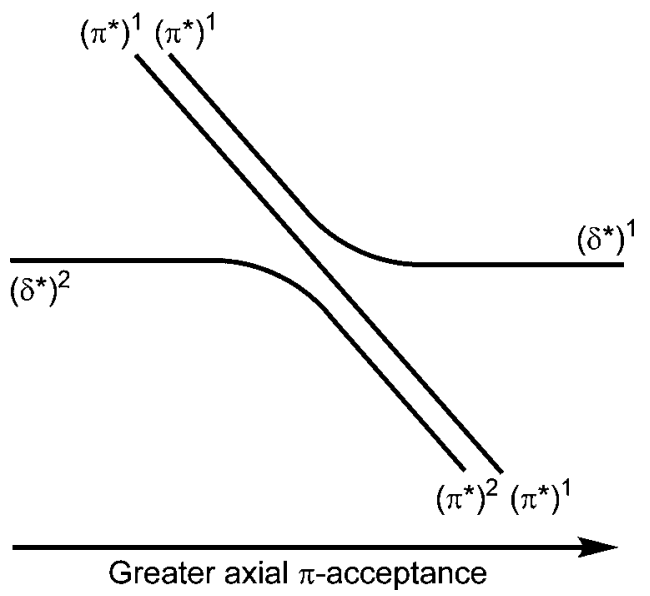

orbital looks more and more like a three-center $\mathrm{Ru}-\mathrm{Ru}-\mathrm{L}_{\mathrm{ax}}$ $\sigma^{\mathrm{nb}}\left(\mathrm{z}^{2}\right)$ orbital (Chart 5). Losing such an important bonding orbital would significantly weaken the bond between the metals, and could allow the axial ligand to abstract the forward $\mathrm{Ru}$ ion. This explanation is supported by a recent study of $\mathrm{M}-$ $\mathrm{M}$ and $\mathrm{M}-\mathrm{L}$ bond orders in $\mathrm{M}_{2}\left(\mathrm{O}_{2} \mathrm{CR}\right)_{4}(\mathrm{~L})_{1-2}$ type complexes at the CASSCF level of theory. ${ }^{5}$ The complexes with $\mathrm{O}, \mathrm{O}$ - and $\mathrm{N}, \mathrm{O}$-donor equatorial ligands are degraded by strong $\sigma$-donors, whereas complexes with $\mathrm{N}, \mathrm{N}$-donor equatorial ligands are not, ${ }^{104-108}$ because the $\mathrm{Ru}-\mathrm{N}_{\mathrm{eq}}$ bond is stronger than the $\mathrm{Ru}-$ $\mathrm{O}_{\text {eq }}$ bond, stabilizing $\mathrm{Ru}_{2}(\mathrm{~N}, \mathrm{~N})_{4}$ complexes to weakening of the $\mathrm{Ru}-\mathrm{Ru}$ bond. This $\mathrm{Ru}$ ion abstraction is not observed in $\mathrm{PPh}_{3}$ adduct 4, which, to our knowledge, has the greatest $\pi^{*}$ stabilization of any triplet $\mathrm{d}^{6}-\mathrm{d}^{6} \mathrm{M}_{2}$ complex that has been synthesized. Hence, it is overly $\sigma$-donating axial ligands like $\mathrm{CO}$ and pyridine that cleave the $\mathrm{Ru}-\mathrm{Ru}$ bond in ${ }^{3} \mathrm{~A}$ complexes, and there is no reason to believe that highly $\pi$-withdrawing axial ligands would do the same. $\mathrm{MeCN}$ and $\mathrm{PPh}_{3}$ are only moderately $\sigma$-donating, so they only cleave the weaker $\mathrm{Ru}-$ $\mathrm{Ru}$ bonds of tetracarboxylate compounds. Contrary to what we would predict based on the hypothesis focusing on $\pi$ character, we anticipate that $\mathrm{NH}_{3}$ may also cleave ${ }^{3} \mathrm{~A} \mathrm{Ru}_{2}$ bonds, whereas adducts of $\mathrm{N}_{2}$ and S-bound DMSO would not.
Chart 5. Interaction of $\mathrm{CO} \sigma$ Orbital with the $\mathrm{Ru}_{2} \sigma$ Orbitals Yielding a Loss of $\mathrm{Ru}-\mathrm{Ru}$ Bonding Interaction

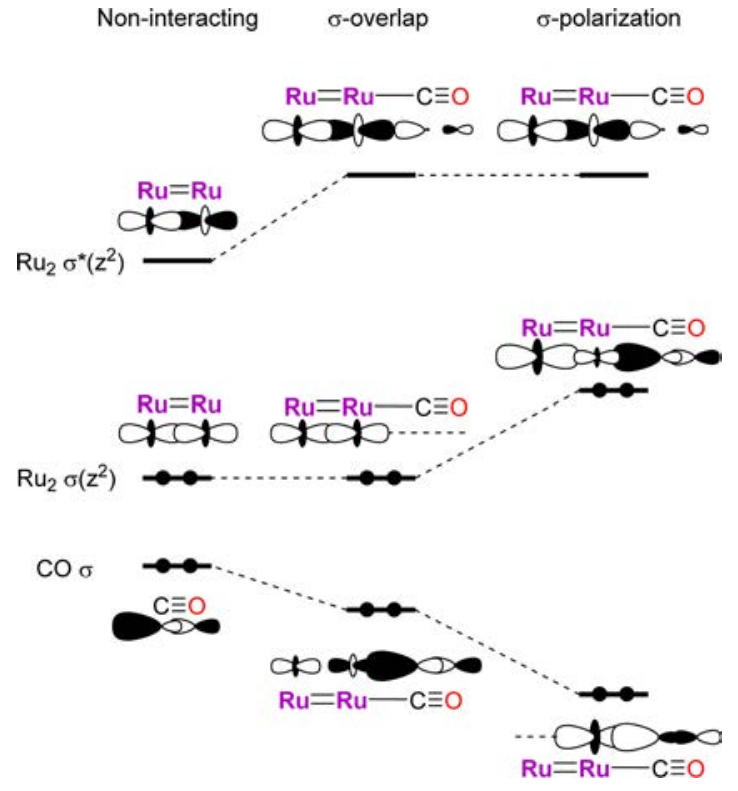

3.5.3. Time-Dependent Density Functional Theory Transition Energies. Electronic transitions were calculated for compounds $\mathbf{2 - 8}$, as well as for the optimized S-bound DMSO adduct, the $\mathrm{CH}_{2} \mathrm{Cl}_{2}$ adduct, and the axially free $\mathrm{Ru}_{2}(\mathrm{chp})_{4}$ using time-dependent (TD) DFT. Throughout the series, Band 1 can almost always be clearly assigned to a single metal-metal transition, namely, $\delta \rightarrow \pi^{*}$. These calculated transition energies and intensities are reported in Table 7 . Band 1 shifts in energy relative to the $\pi$-acidity of the axial ligand, ranging from 10800 $\mathrm{cm}^{-1}$ in 4 , to $12600 \mathrm{~cm}^{-1}$ in 2 and 3 , and the predicted energies of the $\delta \rightarrow \pi^{*}$ transition follow this trend quite closely, with only a slight systematic overestimation of the $\pi^{*}-\delta$ gap. The $\pi$-acidity of the $\mathrm{PPh}_{3}$ ligand is estimated well by the computational model for 4 , placing the average of the two $\delta \rightarrow$ $\pi^{*}$ transitions within $100 \mathrm{~cm}^{-1}$ of the $\nu_{\max }$ value for Band 1 . The error goes up to a $+200 \mathrm{~cm}^{-1}$ overestimation for the less $\pi$ withdrawing $\mathrm{MeCN}$ ligand in 6 and up to $+800 \mathrm{~cm}^{-1}$ for 5 , suggesting that the calculations may underestimate $\pi$-acceptance by pyridine. Complexes $\mathbf{2}$ and $\mathbf{3}$ each have an axial ligand with a single lone pair of $\pi$ symmetry. This situation breaks the $x / y$ degeneracy of the $\delta \rightarrow \pi^{*}$ transition, giving a lower-energy transition near Band $1\left(2,3: 12800 \mathrm{~cm}^{-1}, 13000 \mathrm{~cm}^{-1}\right)$, and a higher-energy transition closer to Band $2\left(2,3: 14000 \mathrm{~cm}^{-1}\right.$, $13800 \mathrm{~cm}^{-1}$ ). If present in solution, the ${ }^{3} \mathrm{E}$ S-bound DMSO adduct is predicted to have a $\pi \rightarrow \delta^{*}$ feature $\left(11700 \mathrm{~cm}^{-1}\right)$ near Band 1 but would have its $\delta \rightarrow \pi^{*}$ transition at $6100 \mathrm{~cm}^{-1}$ with about half of the intensity. However, this lower-energy transition was not observed in the near-IR spectrum of 3 (Figures S6 and S7), suggesting that the isomerization equilibrium strongly favors the O-bound species over the $S$ bound species in solution. Bands 2, 3, and 4 consist of many overlapping transitions, precluding specific assignment.

One question that can be resolved through spectroscopic analysis is the likely identity of the dissolved $\mathrm{Ru}_{2}$ species generated upon $\mathrm{Zn}$ reduction of $\mathbf{1}$ in $\mathrm{CH}_{2} \mathrm{Cl}_{2}$ solution. This red solution maintains its spectroscopic signature, regardless of whether it is generated under $\mathrm{N}_{2}$ or Ar, ruling out the presence of an $\mathrm{N}_{2}$ adduct. The spectrum of this solution is not wellmodeled by axially free $\mathrm{Ru}_{2}(\mathrm{chp})_{4}$ or its $\mathrm{CH}_{2} \mathrm{Cl}_{2}$ adduct (Figure 
Table 7. Energies $\left(\mathrm{cm}^{-1}\right)$ of the TD-DFT-Calculated $\delta \rightarrow \pi^{*}$ Transition in 2-6 and 8 Compared to the Experimental UV-vis Band 1 for Each Solution Being Modeled

\begin{tabular}{|c|c|c|c|c|c|c|}
\hline \multirow[b]{2}{*}{ compound } & \multirow[b]{2}{*}{ solvent } & \multicolumn{2}{|c|}{ Band 1} & \multirow[b]{2}{*}{ DFT model } & \multicolumn{2}{|l|}{$\delta \rightarrow \pi^{*}$} \\
\hline & & $\nu_{\max }\left(\mathrm{cm}^{-1}\right)$ & $\varepsilon\left(\mathrm{M}^{-1} \mathrm{~cm}^{-1}\right)$ & & energy $\left(\mathrm{cm}^{-1}\right)$ & $\varepsilon\left(\mathrm{M}^{-1} \mathrm{~cm}^{-1}\right)$ \\
\hline $2 \mathrm{Ru}_{2}(\mathrm{chp})_{4}(\mathrm{THF})$ & THF & 12600 & 80 & & 12800,14000 & 69,69 \\
\hline \multirow[t]{2}{*}{$3 \mathrm{Ru}_{2}(\mathrm{chp})_{4}(\mathrm{DMSO})$} & DMSO & 12600 & 84 & O-bound & 13000,13800 & 72,68 \\
\hline & & & & S-bound & 6100 & 30 \\
\hline $4 \mathrm{Ru}_{2}(\mathrm{chp})_{4}\left(\mathrm{PPh}_{3}\right)$ & toluene $^{a}$ & 10800 & 55 & & 10500,11100 & 49,47 \\
\hline $5 \mathrm{Ru}_{2}(\mathrm{chp})_{4}(\mathrm{py})$ & pyridine & 11800 & 80 & & 12500,12600 & 66,67 \\
\hline $6 \mathrm{Ru}_{2}(\mathrm{chp})_{4}(\mathrm{MeCN})$ & $\mathrm{MeCN}$ & 11700 & 76 & & 11900 & 65 \\
\hline \multirow[t]{6}{*}{$8\left[\mathrm{Ru}_{2}(\mathrm{chp})_{4}\right]_{2}\left(\mathrm{ZnCl}_{2}\right)^{b}$} & $\mathrm{CH}_{2} \mathrm{Cl}_{2}$ & 12000 & 81 & {$\left[\mathrm{Ru}_{2}(\mathrm{chp})_{4}\right]_{2}\left(\mathrm{ZnCl}_{2}\right)^{b}(\mathrm{HS})$} & $12300,13100,13200$ & $40,46,34$ \\
\hline & & & & {$\left[\mathrm{Ru}_{2}(\mathrm{chp})_{4}\right]_{2}\left(\mathrm{ZnCl}_{2}\right)^{b}(\mathrm{BS})$} & 12 400, 12 400, 13 100, 13100 & $35,19,16,37$ \\
\hline & & & & {$\left[\mathrm{Ru}_{2}(\mathrm{chp})_{4}\right]_{2}^{b}(\mathrm{HS})$} & 12600,14000 & 96,31 \\
\hline & & & & {$\left[\mathrm{Ru}_{2}(\mathrm{chp})_{4}\right]_{2}^{b}(\mathrm{BS})$} & $12600,12600,13700,13700$ & $39,11,45,8$ \\
\hline & & & & $\mathrm{Ru}_{2}(\mathrm{chp})_{4}$ & 12800 & 18 \\
\hline & & & & $\mathrm{Ru}_{2}(\mathrm{chp})_{4}\left(\mathrm{CH}_{2} \mathrm{Cl}_{2}\right)$ & 11500,13900 & 60,43 \\
\hline
\end{tabular}

${ }^{a}$ Also contains 10 additional equiv of $\mathrm{PPh}_{3} .{ }^{b}$ Molar absorptivity calculations based on each $\mathrm{Ru}_{2}$ unit, not on the entire complex.

13). However, the transitions predicted for the broken symmetry model of 7 fit all of the features in the spectrum,

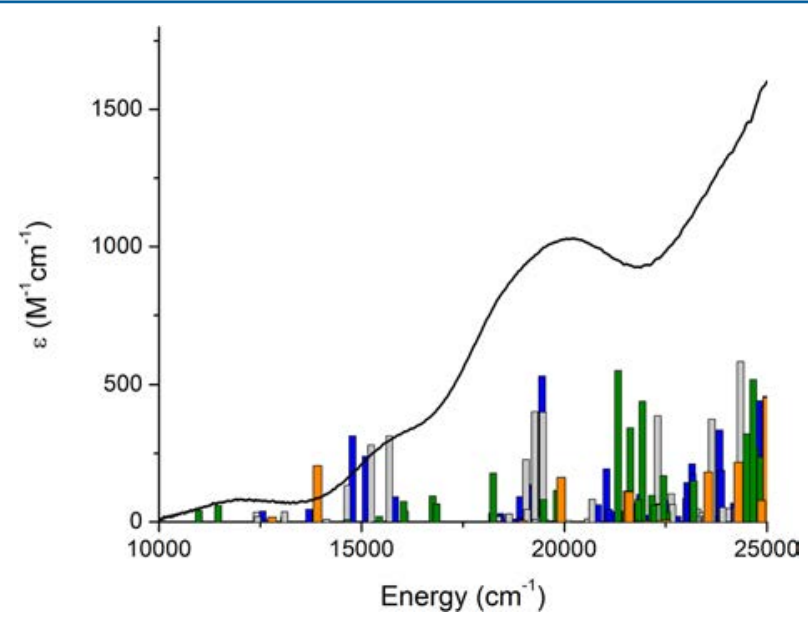

Figure 13. UV-vis spectrum of $\left[\mathrm{Ru}_{2}(\mathrm{chp})_{4}\right]$ generated in $\mathrm{CH}_{2} \mathrm{Cl}_{2}$, compared to the TD-DFT-predicted electronic transitions for $\mathrm{Ru}_{2}(\mathrm{chp})_{4}$ (orange), $\mathrm{Ru}_{2}(\mathrm{chp})_{4}\left(\mathrm{CH}_{2} \mathrm{Cl}_{2}\right)$ (green), 7 (blue), and 8 (gray).

and the broken symmetry model of $\mathbf{8}$ fits Band ${ }_{\text {II }}$ even better. The broken symmetry model for $\mathbf{8}$ gives $\delta \rightarrow \pi^{*}$ transitions that overestimate the Band 1 energy by an average of $750 \mathrm{~cm}^{-1}$, an error that would be typical in this series for $\mathrm{a} \mathrm{Ru}_{2}$ center that is not experiencing any significant axial $\pi$-withdrawing or $\pi$ donating effects. Hence, dimer $\mathbf{8}$ is likely already the dominant species in the red solution prior to precipitation or crystallization. The solubility of $\mathbf{8}$ in $\mathrm{CH}_{2} \mathrm{Cl}_{2}$ is thus an intrinsic property of that complex, rather than a result of the dimer being split by solvolysis.

3.5.4. Binding Constants and Synthetic Implications. To better understand the stability and reactivity of the $\mathrm{Ru}_{2}(\mathrm{chp})_{4}$ axial adducts, we have sought to use our computational results to predict the binding constant $\left(K_{\mathrm{b}}\right)$ for each axial ligand in the reaction:

$$
\mathrm{Ru}_{2}(\operatorname{chp})_{4}+\mathrm{L} \rightleftharpoons \mathrm{Ru}_{2}(\operatorname{chp})_{4} \mathrm{~L}
$$

In pursuit of an explanation for the puzzling absence of any synthesized complexes with a $3 \mathrm{E}$-derived ground state, a plot of the resulting binding energies (proportional to the binding constants $K_{\mathrm{b}}$ on a log scale) against the $\pi^{*}-\delta^{*}(x y)$ gap $(\Delta)$ in the symmetry-pure orbital energies for each complex can be used to determine if $\pi$-withdrawing character is inherently destabilizing to axial coordination (Figure 14a). The value of $\Delta$ is a good measure of the $\pi$-donating/withdrawing character of
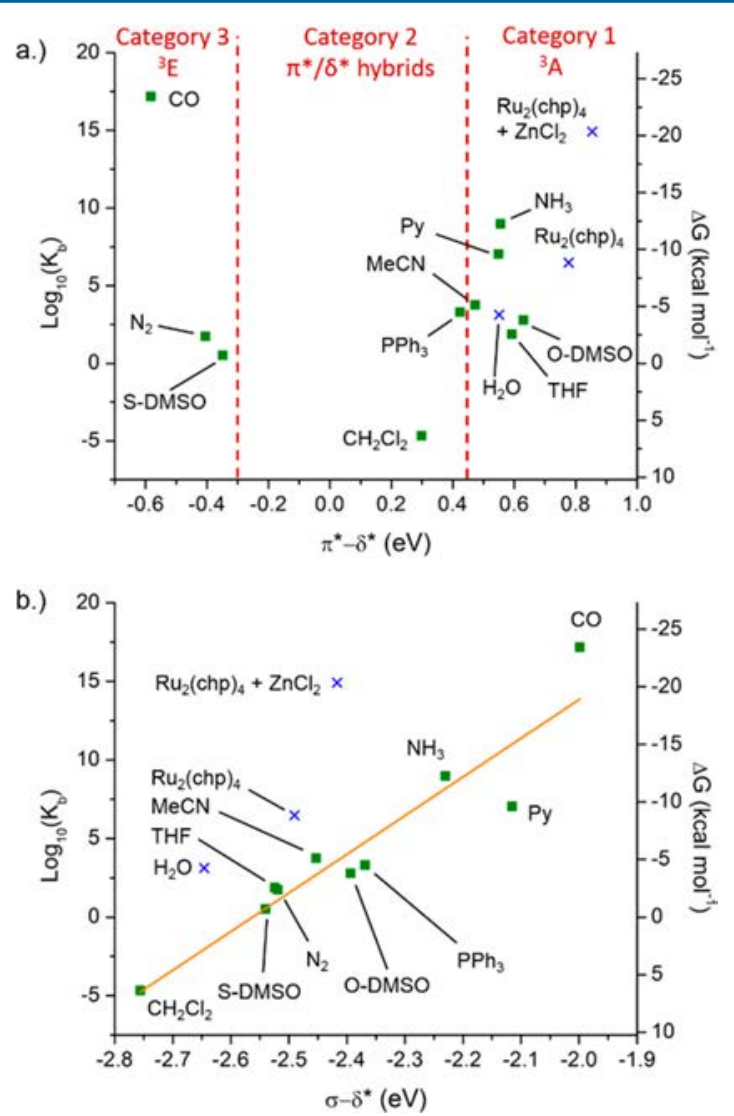

Figure 14. DFT-calculated binding constants for the simple axial adducts (green $\boldsymbol{\square}$ ) and the multicoordinating complexes (blue $\times$ ) plotted on a log scale against (a) the calculated $\pi^{*}-\delta^{*}$ gap and (b) the calculated $\sigma-\delta^{*}$ gap. In (b), a linear fit of the simple adduct data (orange -) was found as $y=24.61 x+63.069$, with $R^{2}=0.88$. The delineation between Categories 2 and 3 in (a) is not uniquely defined. 
the axial ligands here because none of the axial ligands possess orbitals of the appropriate symmetry to overlap with the $\mathrm{Ru}_{2} \delta^{*}$ orbital. Though there is a vast empty region in our series between the $\Delta$ values of 0.3 and $-0.3 \mathrm{eV}$, there is no obvious trend that might suggest that negative values of $\Delta$ are necessarily destabilizing. In fact, both the highest binding constant and the most negative $\Delta$ value of the series are given by $\mathrm{CO}$, which is, coincidentally, unstable to $\mathrm{Ru}-\mathrm{Ru}$ cleavage for reasons previously discussed (vide supra). The large differences in binding energy between $\mathrm{CO}$ and the other Category 3 complexes, or between the two Category 2 complexes, suggest that the $\pi$ character of the axial ligand does not strongly influence its binding strength to $\mathrm{Ru}_{2}(\mathrm{chp})_{4}$.

On the contrary, when the binding energies are plotted against the $\sigma-\delta^{*}(x y)$ gap (a good descriptor for the $\sigma$-donating ability of each axial ligand) for each complex (Figure 14b), a trend immediately emerges. The binding strength for the axial ligand increases roughly linearly with its $\sigma$-donation. Multicoordinating complexes (dimers, $\mathrm{H}_{2} \mathrm{O}$ ) appear above this line, because their binding energy is supplemented by second-sphere interactions. This trend explains the synthetic results remarkably well. Dimer 7 is the thermodynamic sink for $\mathrm{Ru}_{2}(\mathrm{chp})_{4}$ in most solvents, and having $\mathrm{ZnCl}_{2}$ present stabilizes dimerization even further by forming $\mathbf{8}$. Hence, the adducts of $\mathrm{CH}_{2} \mathrm{Cl}_{2}$ and $\mathrm{N}_{2}$ are not observed because these ligands are not $\sigma$-donating enough to shift the equilibrium of eq 2 away from dimerization. $\mathrm{N}_{2}$ is about as $\sigma$-donating as THF, but adduct $\mathbf{2}$ is obtained (in low yield) when THF can be used as solvent. $\mathrm{N}_{2}$ could therefore be a feasible axial ligand, but would leave the $\mathrm{Ru}_{2}$ complex unstable to dimerization. Though the binding energy data for $\mathrm{H}_{2} \mathrm{O}$ suggests that it should be a decent axial ligand, its $\sigma$-donation is rather weak. The higher binding energy calculated for $\mathrm{H}_{2} \mathrm{O}$ is due to the hydrogen-bonded multicoordinating model of a single water molecule in proximity to $\mathrm{Ru}_{2}(\mathrm{chp})_{4}$. As suggested by the long $\mathrm{Ru}-\mathrm{Ru}$ distance observed in preliminary models with additional water molecules, in a real solution, this direct hydrogen bonding to $\mathrm{O}_{\text {chp }}$ would be disrupted, and the coordinated $\mathrm{H}_{2} \mathrm{O}$ molecule would achieve a similar binding strength as a simple ligand via $\sigma$-donation through its oxygen atom. Thus far, all of our attempts to prepare the $\mathrm{H}_{2} \mathrm{O}$ adduct have resulted only in dimer 7, likely due to insolubility.

DMSO clearly shows a thermodynamic preference for binding through its oxygen rather than its sulfur due to differences in $\sigma$-donation from these two atoms. The calculated thermodynamic parameters suggest that a DMSO solution of 3 at $25{ }^{\circ} \mathrm{C}$ would be only $0.5 \%$ S-bound $\left(\Delta G_{\mathrm{O} \rightarrow \mathrm{S}}=3.1 \mathrm{kcal}\right.$ $\left.\mathrm{mol}^{-1}\right)$, and this rises to only $1.2 \%\left(\Delta G_{\mathrm{O} \rightarrow \mathrm{S}}=3.3 \mathrm{kcal} \mathrm{mol}^{-1}\right)$ at $100{ }^{\circ} \mathrm{C}$ and to $2.1 \%\left(\Delta G_{\mathrm{O} \rightarrow \mathrm{S}}=3.5 \mathrm{kcal} \mathrm{mol}^{-1}\right)$ at $189{ }^{\circ} \mathrm{C}$ (the boiling point of DMSO). However, even with O-bound 3, extra DMSO still must be present to shift the equilibrium away from dimerization, as demonstrated in the degradation of yellow crystals of 3 to brown 7 under water or vacuum. Similarly, a 10fold excess of the moderate $\sigma$-donor $\mathrm{PPh}_{3}$ is necessary to prevent green 4 in toluene solution from converting to a peachorange complex, which is likely the solubilized form of brown 7 . $\mathrm{MeCN}$ is a moderate $\sigma$-donor that should bind well enough in solution to shift the equilibrium toward the solvent adduct, but the poor solubility of both $\mathbf{6}$ and the dimer in MeCN keeps the average local concentration around each $\mathrm{Ru}_{2}(\mathrm{chp})_{4}$ unit relatively low. Hence, 6 can be made in dilute solutions, and can even be kinetically trapped by crystallization, but any factors that might increase the rate of reaction (heating, stirring, grinding the crystals, too many nucleation sites due to a solid reductant) will cause irreversible dimerization. Pyridine has the highest binding energy of any of the adducts that have been isolated due to its strong $\sigma$-donation. This explains the high stability of $\mathbf{5}$ against substitution and oxidation in air and in solution, as well as the solubility of dimers 7 and $\mathbf{8}$ in pyridine. These results also predict that $\mathrm{NH}_{3}$ should be a similarly strong ligand, giving stronger binding with less likelihood of $\mathrm{Ru}-\mathrm{Ru}$ cleavage than pyridine. $\mathrm{CO}$ is predicted to bind to $\mathrm{Ru}_{2}(\mathrm{chp})_{4}$ stronger than any other ligand in the series, but as previously discussed, it breaks the $\mathrm{Ru}-\mathrm{Ru}$ bond through its strong $\sigma$ donation.

\section{SUMMARY AND CONCLUDING REMARKS}

The range of axial adducts of the $(\mathrm{N}, \mathrm{O})$-type paddlewheel diruthenium (II,II) complex $\mathrm{Ru}_{2}(\mathrm{chp})_{4}$ has been greatly expanded. The DMSO, $\mathrm{MeCN}, \mathrm{PPh}_{3}$, and pyridine adducts, as well as the dimer $\left[\mathrm{Ru}_{2}(\mathrm{chp})_{4}\right]_{2}\left(\mathrm{ZnCl}_{2}\right)$ and the $\mathrm{Ru}-\mathrm{Ru}$ cleaved species $(\mu \text {-chp })_{2}\left[\mathrm{Ru}\left(\eta^{2} \text {-chp }\right)(\mathrm{CO})_{2}\right]_{2}$, have been characterized crystallographically, and a new crystallographic form of the THF adduct has been prepared. The thermodynamic sink of most of these reactions, the dimer $\left[\mathrm{Ru}_{2}(\mathrm{chp})_{4}\right]_{2}$, has been identified and isolated. All of the adducts have been characterized spectroscopically, and those of pyridine and $\mathrm{PPh}_{3}$, as well as the $\mathrm{ZnCl}_{2}$-bound dimer, have been characterized magnetically. DFT calculations on the adducts, the dimers, and the hypothetical $\mathrm{CH}_{2} \mathrm{Cl}_{2}, \mathrm{H}_{2} \mathrm{O}$, S-bound DMSO, $\mathrm{N}_{2}, \mathrm{NH}_{3}$, and $\mathrm{CO}$ adducts have given insight into how the axial ligand influences the $\mathrm{Ru}_{2}$ (II,II) electronic structure and have shown that the $\sigma$-interaction with the axial ligand dominates both ligand-binding and $\mathrm{Ru}-\mathrm{Ru}$ bond cleavage. Ground states derived from ${ }^{3} \mathrm{E}$ are not inherently unstable and should be accessible in $\mathrm{Ru}_{2}(\mathrm{chp})_{4}$ adducts with moderately $\sigma$-donating and highly $\pi$-withdrawing axial ligands. Such a compound is prone to Jahn-Teller distortion, which we predict to occur via symmetry lowering to $C_{2}$. Additionally, we have described a new $\pi^{*} / \delta^{*}$-hybridized electronic ground state for $\mathrm{M}_{2} \mathrm{~d}^{6}-\mathrm{d}^{6}$ complexes, namely, ${ }^{3} \mathrm{~A}^{\prime \prime}\left(\pi^{*}\right)^{1}\left(\pi^{*} / \delta^{*}\right)^{3}$, that arises from pseudoJahn-Teller distortions to $C_{s}$ symmetry near the crossing point of ${ }^{3} \mathrm{~A}\left(\pi^{*}\right)^{2}\left(\delta^{*}\right)^{2}$ and ${ }^{3} \mathrm{E}\left(\pi^{*}\right)^{3}\left(\delta^{*}\right)^{1}$. This intermediate state cannot be distinguished by magnetic measurements but manifests via an abnormally long $\mathrm{Ru}-\mathrm{Ru}$ bond and a loss of axial symmetry in $\mathrm{Ru}_{2}(\mathrm{chp})_{4}\left(\mathrm{PPh}_{3}\right)$.

\section{ASSOCIATED CONTENT}

\section{S Supporting Information}

The Supporting Information is available free of charge on the ACS Publications website at DOI: 10.1021/acs.inorgchem.5b01241.

Background, crystallography, spectroscopy, XYZ files for DFT-optimized geometries, structural properties of DFT-optimized adducts, derivation of symmetry-pure orbital energies, TD-DFT electronic transitions overlaid on each UV-vis spectrum, and Cartesian coordinates for all of the optimized structures. (PDF)

Crystallographic data. (CIF)

\section{AUTHOR INFORMATION}

\section{Corresponding Author}

*E-mail: berry@chem.wisc.edu.

\section{Notes}

The authors declare no competing financial interest. 


\section{ACKNOWLEDGMENTS}

The authors acknowledge financial support from the Dept. of Energy (DE-FG02-10ER16204), the National Science Foundation Grant No. CHE-0840494 (computing cluster), the CNRS, the Aquitaine Region, the Univ. of Bordeaux, and a generous gift from Paul J. Bender (Bruker Quazar APEX2, Bruker Avance 500).

\section{REFERENCES}

(1) Multiple Bonds between Metal Atoms; Cotton, F. A., Murillo, C. A., Walton, R. A., Eds.; 3rd ed.; Springer Science: New York, 2005.

(2) Patmore, N. J. In Organometallic Chemistry; The Royal Society of Chemistry: London, U.K., 2010; Vol. 36, pp 77-92.

(3) Ren, T. C. R. Chim. 2008, 11, 684-692.

(4) Koberl, M.; Cokoja, M.; Herrmann, W. A.; Kuhn, F. E. Dalton Trans. 2011, 40, 6834-6859.

(5) Fritsch, N.; Wick, C. R.; Waidmann, T.; Dral, P. O.; Tucher, J.; Heinemann, F. W.; Shubina, T. E.; Clark, T.; Burzlaff, N. Inorg. Chem. 2014, 53, 12305-12314.

(6) Miskowski, V. M.; Hopkins, M. D.; Winkler, J. R.; Gray, H. B. In Inorganic Electronic Structure and Spectroscopy, Vol. II: Applications and Case Studies; Solomon, E. I., Lever, A. B. P., Eds.; John Wiley \& Sons, Inc.: New York, 1999; pp 343-402.

(7) Ren, T. Organometallics 2005, 24, 4854-4870.

(8) Xi, B.; Ren, T. C. R. Chim. 2009, 12, 321-331.

(9) Miyasaka, H. Acc. Chem. Res. 2013, 46, 248-257.

(10) Miyasaka, H.; Motokawa, N.; Atsuumi, R.; Kamo, H.; Asai, Y.; Yamashita, M. Dalton Trans. 2011, 40, 673-682.

(11) Mikuriya, M.; Yoshioka, D.; Handa, M. Coord. Chem. Rev. 2006, 250, 2194-2211.

(12) Miyasaka, H.; Clérac, R.; Campos-Fernandez, C. S.; Dunbar, K. R. J. Chem. Soc., Dalton Trans. 2001, 858-861.

(13) Chiarella, G. M.; Cotton, F. A.; Murillo, C. A.; Ventura, K.; Villagrán, D.; Wang, X. J. Am. Chem. Soc. 2014, 136, 9580-9589.

(14) Berry, J. F. J. Chem. Sci. 2015, 127, 209-214.

(15) Kadish, K. M.; Han, B.; Shao, J.; Ou, Z.; Bear, J. L. Inorg. Chem. 2001, 40, 6848-6851.

(16) Ren, T.; Zou, G.; Alvarez, J. C. Chem. Commun. 2000, 11971198

(17) Kornecki, K. P.; Berry, J. F.; Powers, D. C.; Ritter, T. In Progress in Inorganic Chemistry; John Wiley \& Sons, Inc.: Hoboken, NJ, 2014; Vol. 58, pp 225-302.

(18) Pap, J. S.; DeBeer George, S.; Berry, J. F. Angew. Chem., Int. Ed. 2008, 47, 10102-10105.

(19) Long, A. K. M.; Timmer, G. H.; Pap, J. S.; Snyder, J. L.; Yu, R. P.; Berry, J. F. J. Am. Chem. Soc. 2011, 133, 13138-13150.

(20) Musch Long, A. K.; Yu, R. P.; Timmer, G. H.; Berry, J. F. J. Am. Chem. Soc. 2010, 132, 12228-12230.

(21) Corcos, A. R.; Long, A. K. M.; Guzei, I. A.; Berry, J. F. Eur. J. Inorg. Chem. 2013, 2013, 3808-3811.

(22) Curley, J. J.; Cook, T. R.; Reece, S. Y.; Müller, P.; Cummins, C. C. J. Am. Chem. Soc. 2008, 130, 9394-9405.

(23) Coia, G. M.; Demadis, K. D.; Meyer, T. J. Inorg. Chem. 2000, 39, 2212-2223.

(24) Field, L. D.; Li, H. L.; Dalgarno, S. J. Inorg. Chem. 2010, 49, 6214-6221.

(25) Drago, R. S. Inorg. Chem. 1982, 21, 1697-1698.

(26) Drago, R. S.; Long, J. R.; Cosmano, R. Inorg. Chem. 1982, 21, 2196-2202.

(27) Drago, R. S.; Long, J. R.; Cosmano, R. Inorg. Chem. 1981, 20, 2920-2927.

(28) Drago, R. S.; Tanner, S. P.; Richman, R. M.; Long, J. R. J. Am. Chem. Soc. 1979, 101, 2897-2903.

(29) Lindsay, A. J.; Wilkinson, G.; Motevalli, M.; Hursthouse, M. B. J. Chem. Soc., Dalton Trans. 1985, 2321-2326.

(30) Lindsay, A. J.; Wilkinson, G.; Motevalli, M.; Hursthouse, M. B. J. Chem. Soc., Dalton Trans. 1987, 2723-2736.
(31) Furukawa, S.; Ohba, M.; Kitagawa, S. Chem. Commun. 2005, $865-867$.

(32) Motokawa, N.; Oyama, T.; Matsunaga, S.; Miyasaka, H.; Sugimoto, K.; Yamashita, M.; Lopez, N.; Dunbar, K. R. Dalton Trans. 2008, 4099-4102.

(33) Motokawa, N.; Oyama, T.; Matsunaga, S.; Miyasaka, H.; Yamashita, M.; Dunbar, K. R. CrystEngComm 2009, 11, 2121-2130.

(34) Miyasaka, H.; Motokawa, N.; Matsunaga, S.; Yamashita, M.; Sugimoto, K.; Mori, T.; Toyota, N.; Dunbar, K. R. J. Am. Chem. Soc. 2010, 132, 1532-1544.

(35) Nakabayashi, K.; Nishio, M.; Kubo, K.; Kosaka, W.; Miyasaka, H. Dalton Trans. 2012, 41, 6072-6074.

(36) Nozaki, T.; Kosaka, W.; Miyasaka, H. CrystEngComm 2012, 14, 5398-5401.

(37) Kosaka, W.; Yamamoto, N.; Miyasaka, H. Inorg. Chem. 2013, 52, 9908-9914.

(38) Kosaka, W.; Yamagishi, K.; Hori, A.; Sato, H.; Matsuda, R.; Kitagawa, S.; Takata, M.; Miyasaka, H. J. Am. Chem. Soc. 2013, 135, 18469-18480.

(39) Kosaka, W.; Yamagishi, K.; Yoshida, H.; Matsuda, R.; Kitagawa, S.; Takata, M.; Miyasaka, H. Chem. Commun. 2013, 49, 1594-1596.

(40) Nakabayashi, K.; Miyasaka, H. Chem. - Eur. J. 2014, 20, 51215131.

(41) Kosaka, W.; Yamagishi, K.; Zhang, J.; Miyasaka, H. J. Am. Chem. Soc. 2014, 136, 12304-12313.

(42) Cotton, F. A.; Ren, T. Inorg. Chem. 1991, 30, 3675-3679.

(43) Cotton, F. A.; Falvello, L. R.; Ren, T.; Vidyasagar, K. Inorg. Chim. Acta 1992, 194, 163-170.

(44) Cotton, F. A.; Ren, T.; Eglin, J. L. Inorg. Chem. 1991, 30, 25522558.

(45) Cotton, F. A.; Kim, Y.; Yokochi, A. Inorg. Chim. Acta 1995, 236, $55-61$.

(46) Cotton, F. A.; Feng, X. Inorg. Chem. 1989, 28, 1180-1183.

(47) Estiú, G.; Cukiernik, F. D.; Maldivi, P.; Poizat, O. Inorg. Chem. 1999, 38, 3030-3039.

(48) Cotton, F. A.; Ren, T.; Eglin, J. L. J. Am. Chem. Soc. 1990, 112, 3439-3445.

(49) Girolami, G. S.; Andersen, R. A. Inorg. Chem. 1981, 20, 20402044.

(50) Mitchell, R. W.; Spencer, A.; Wilkinson, G. J. Chem. Soc., Dalton Trans. 1973, 846-854.

(51) In an alternative method, a Schlenk flask containing $\mathrm{Ru}_{2}(\mathrm{chp}){ }_{4} \mathrm{Cl}(102 \mathrm{mg}, 0.136 \mathrm{mmol})$ and zinc dust $(72 \mathrm{mg}, 1.1$ $\mathrm{mmol})$ was charged with dimethylsulfoxide $(0.5 \mathrm{~mL})$ followed by dichloromethane $(20 \mathrm{~mL})$. The dark purple mixture was stirred for 25 min, during which a color change to dark yellow was observed. The mixture was filtered through Celite, giving a yellow-brown filtrate that was evaporated under reduced pressure. The resulting slurry was filtered in air, rapidly washing with ethyl acetate $(10 \mathrm{~mL})$ and hexanes $(10 \mathrm{~mL})$, to give a yellow-brown microcrystalline solid. Estimated yield: $7.1 \mathrm{mg}(8.6 \%)$. IR (ATR, cm $\left.{ }^{-1}\right): 3096 \mathrm{vw}, 1940 \mathrm{w}, 1605 \mathrm{~m}$, $1530 \mathrm{~m}, 1474 \mathrm{~s}, 1444 \mathrm{~s}, 1391 \mathrm{~m}, 1360 \mathrm{w}, 1221 \mathrm{w}, 1167 \mathrm{~m}, 1072 \mathrm{w}$, 1014 m, 928 m, 777 s, 725 m, 713 m, 651 w. MALDI-TOF $(\mathrm{m} / z): 718$ $[\mathrm{M}-\mathrm{DMSO}]^{+}, 796[\mathrm{M}]^{+}, 811[\mathrm{M}-\mathrm{DMSO}+\mathrm{chp}-\mathrm{Cl}+\mathrm{H}]^{+}, 1398$ $\left[(\mathrm{M}-\mathrm{DMSO})_{2}-\mathrm{Cl}\right]^{+}, 1433\left[(\mathrm{M}-\mathrm{DMSO})_{2}\right]^{+}, 1468\left[(\mathrm{M}-\mathrm{DMSO})_{2}+\right.$ $\mathrm{Cl}]^{+}, 1526\left[(\mathrm{M}-\mathrm{DMSO})_{2}+\mathrm{chp}-\mathrm{Cl}\right]^{+}$. The compound's instability in air, vacuum, and solvents other than DMSO precluded further purification or more extensive characterizations.

(52) Bruker-AXS. APEX2 (Ver. 2013.2-0), SADABS (2012-1), and SAINT+ (Ver. 8.30C) Software Reference Manuals; Bruker-AXS: Madison, WI, 2013.

(53) (a) Dolomanov, O. V.; Bourhis, L. J.; Gildea, R. J.; Howard, J. A. K.; Puschmann, H. J. Appl. Crystallogr. 2009, 42, 339-341. (b) Sheldrick, G. M. XS, v. 2013/1.; Georg-August-Universität Göttingen: Göttingen, Germany, 2013. (c) Sheldrick, G. M. Acta Crystallogr., Sect. C: Struct. Chem. 2015, C71, 3-8.

(54) Neese, F. ORCA, An Ab Initio, Density Functional and Semiempirical Program Package, v. 2.9.1.; Max-Planck-Institute for Bioinorganic Chemistry: Ruhr, Germany, 2012. 
(55) Weigend, F.; Ahlrichs, R. Phys. Chem. Chem. Phys. 2005, 7, 3297-3305.

(56) Perdew, J. P. Phys. Rev. B: Condens. Matter Mater. Phys. 1986, 33, 8822-8824.

(57) Becke, A. D. Phys. Rev. A: At., Mol., Opt. Phys. 1988, 38, 30983100 .

(58) Neese, F. J. Comput. Chem. 2003, 24, 1740-1747.

(59) Weigend, F. Phys. Chem. Chem. Phys. 2006, 8, 1057-1065.

(60) Hanwell, M.; Curtis, D.; Lonie, D.; Vandermeersch, T.; Zurek, E.; Hutchison, G. J. Cheminf. 2012, 4, 17.

(61) Kossmann, S.; Kirchner, B.; Neese, F. Mol. Phys. 2007, 105, 2049-2071.

(62) Stephens, P. J.; Devlin, F. J.; Chabalowski, C. F.; Frisch, M. J. J.

Phys. Chem. 1994, 98, 11623-11627.

(63) Kossmann, S.; Neese, F. J. Chem. Theory Comput. 2010, 6, $2325-2338$.

(64) Neese, F. J. Am. Chem. Soc. 2006, 128, 10213-10222.

(65) Pettersen, E. F.; Goddard, T. D.; Huang, C. C.; Couch, G. S.; Greenblatt, D. M.; Meng, E. C.; Ferrin, T. E. J. Comput. Chem. 2004, $25,1605-1612$.

(66) Neese, F. J. Phys. Chem. Solids 2004, 65, 781-785.

(67) Neese, F.; Olbrich, G. Chem. Phys. Lett. 2002, 362, 170-178.

(68) Petrenko, T.; Kossmann, S.; Neese, F. J. Chem. Phys. 2011, 134, 054116.

(69) Sinnecker, S.; Rajendran, A.; Klamt, A.; Diedenhofen, M.; Neese, F. J. Phys. Chem. A 2006, 110, 2235-2245.

(70) Gilson, M. K.; Irikura, K. K. J. Phys. Chem. B 2010, 114, 1630416317.

(71) Lutterman, D. A.; Degtyareva, N. N.; Johnston, D. H.; Gallucci, J. C.; Eglin, J. L.; Turro, C. Inorg. Chem. 2005, 44, 5388-5396.

(72) $\mathrm{Zn}\left(\mathrm{OPPh}_{3}\right)_{2} \mathrm{Cl}_{2}$ crystallized from toluene/hexanes in the monoclinic space group $C c$ with unit cell dimensions $a=19.768(9)$ $\AA, b=10.219(5) \AA, c=18.486(9) \AA$, and $\beta=118.50(2)^{\circ}$ (cell volume $\left.=3282(3) \AA^{3} ; Z=4\right)$. Least-square refinement yielded $R_{1}$ and $w R_{2}$ values of 0.0454 and 0.0973 for $I>2 \sigma(I)$ data, and 0.0580 and 0.1025 for all data.

(73) $(\mu \text {-chp })_{2}\left[\mathrm{Ru}(\mathrm{chp})(\mathrm{CO})_{2}\right]_{2}$ crystallized from $\mathrm{CHCl}_{3}$ in the monoclinic space group $P 2_{1} / c$ with unit cell dimensions $a=11.070(6)$ $\AA, b=19.718(10) \AA, c=12.991(6) \AA$, and $\beta=109.82(3)^{\circ}$ (cell volume $\left.=2668(2) \AA^{3} ; Z=4\right)$. Least-square refinement yielded $R_{1}$ and $w R_{2}$ values of 0.0498 and 0.1040 for $I>2 \sigma(I)$ data, and 0.1052 and 0.1283 for all data. The compound is diamagnetic, as evidenced by: ${ }^{1} \mathrm{H}$ NMR $\left(400 \mathrm{MHz}, \mathrm{CDCl}_{3}\right): \delta=7.47(\mathrm{dd}, J=8.6,7.7 \mathrm{~Hz}, 4 \mathrm{H}), 6.57$ $(\mathrm{dd}, J=7.6,0.9 \mathrm{~Hz}, 4 \mathrm{H}), 6.26(\mathrm{dd}, J=8.6,0.9 \mathrm{~Hz}, 4 \mathrm{H}) .{ }^{13} \mathrm{C}$ NMR $\left(126 \mathrm{MHz}, \mathrm{CDCl}_{3}\right): \delta=192.92,178.33,148.61,141.92,111.34$, 109.44. IR (ATR, cm ${ }^{-1}$ ): 3094 vw, 2963 vw, 2056 m, 2050 s, 1990 m, $1974 \mathrm{~s}, 1599 \mathrm{~m}, 1540 \mathrm{w}, 1451 \mathrm{~s}, 1441 \mathrm{~s}, 1356 \mathrm{w}, 1261 \mathrm{~m}, 1182 \mathrm{w}, 1172$ w, 1083 br, 1018 m, 1010 m, 941 m, 922 m, 873 w, 796 s, 779 m, 739 w, $706 \mathrm{w}, 630 \mathrm{w}$.

(74) $3 \cdot 0.8 \mathrm{DMSO}$ crystallized from $\mathrm{DMSO} /$ water in the triclinic space group $P 2_{1} / c$ with unit cell dimensions $a=13.096(5) \AA, b=$ 13.240(6) $\AA, c=17.420(7) \AA, \alpha=93.429(6)^{\circ}, \beta=96.26(3)^{\circ}$ and $\gamma=$ $90.243(10)^{\circ}\left(\right.$ cell volume $\left.=2997(2) \AA^{3} ; Z=2\right)$. Least-square refinement yielded $R_{1}$ and $w R_{2}$ values of 0.0974 and 0.1953 for $I>$ $2 \sigma(I)$ data, and 0.1162 and 0.2030 for all data. The average $\mathrm{Ru}-\mathrm{Ru}$ distance is $2.253[3] \AA$.

(75) Gracia, R.; Adams, H.; Patmore, N. J. Inorg. Chim. Acta 2010, 363, 3856-3864.

(76) Pyykkö, P.; Atsumi, M. Chem. - Eur. J. 2009, 15, 186-197.

(77) Dong, H.; Meng, Q.; Chen, B.-Z.; Wu, Y.-B. J. Organomet. Chem. 2012, 717, 108-115.

(78) Coe, B. J.; Glenwright, S. J. Coord. Chem. Rev. 2000, 203, 5-80. (79) Smith, M. K.; Gibson, J. A.; Young, C. G.; Broomhead, J. A.; Junk, P. C.; Keene, F. R. Eur. J. Inorg. Chem. 2000, 2000, 1365-1370.

(80) Arnett, E. M.; Mitchell, E. J.; Murty, T. S. S. R. J. Am. Chem. Soc. 1974, 96, 3875-3891.

(81) Bush, R. C.; Angelici, R. J. Inorg. Chem. 1988, 27, 681-686.

(82) Maria, P. C.; Gal, J. F. J. Phys. Chem. 1985, 89, 1296-1304.
(83) Sandström, M.; Persson, I.; Persson, P. Acta Chem. Scand. 1990, 44, 653-675.

(84) Litke, S. V.; Ershov, A. Y. Opt. Spectrosc. 2011, 110, 522-528.

(85) Beach, N. A.; Gray, H. B. J. Am. Chem. Soc. 1968, 90, 57135721.

(86) Gray, H. B.; Beach, N. A. J. Am. Chem. Soc. 1963, 85, 29222927.

(87) Ziegler, T.; Rauk, A. Inorg. Chem. 1979, 18, 1755-1759.

(88) Angaridis, P. In Multiple Bonds between Metal Atoms; Cotton, F. A., Murillo, C. A., Walton, R. A., Eds.; Springer Science: New York, 2005; pp 377-430.

(89) Boča, R. Coord. Chem. Rev. 2004, 248, 757-815.

(90) Cotton, F. A.; Miskowski, V. M.; Zhong, B. J. Am. Chem. Soc. 1989, 111, 6177-6182.

(91) Dikarev, E. V.; Filatov, A. S.; Clérac, R.; Petrukhina, M. A. Inorg. Chem. 2006, 45, 744-751.

(92) Bonnet, L.; Cukiernik, F. D.; Maldivi, P.; Giroud-Godquin, A. M.; Marchon, J. C.; Ibn-Elhaj, M.; Guillon, D.; Skoulios, A. Chem. Mater. 1994, 6, 31-38.

(93) Considering our findings with compound 2, we suggest that the low $g$ value of its fhp analogue is due to the presence of $\left[\mathrm{Ru}_{2}(\mathrm{fhp})_{4}\right]_{2}$ dimer, or unknown diamagnetic impurities.

(94) Cogne, A.; Belorizky, E.; Laugier, J.; Rey, P. Inorg. Chem. 1994, 33, 3364-3369.

(95) The amount of paramagnetic impurity was estimated to be $\rho=$ $1.2 \%$.

(96) Soda, T.; Kitagawa, Y.; Onishi, T.; Takano, Y.; Shigeta, Y.; Nagao, H.; Yoshioka, Y.; Yamaguchi, K. Chem. Phys. Lett. 2000, 319, 223-230.

(97) 5 cocrystallized from DMSO/water with a $25.2(4) \%$ wholemolecule-disordered component of 3 in the monoclinic space group $P 2_{1} / c$ with unit cell dimensions $a=17.570(5) \AA, b=9.389(4) \AA$ (4) $c=$ 18.595(7) $\AA, \beta=115.11(2)^{\circ}$ (cell volume $\left.=2778(2) \AA^{3} ; Z=4\right)$. Leastsquare refinement yielded $R_{1}$ and $w R_{2}$ values of 0.0365 and 0.0692 for $I>2 \sigma(I)$ data, and 0.0465 and 0.0721 for all data. The pyridine of the 5 component is staggered relative to the equatorial ligand oxygen atoms. Both components share a $\mathrm{Ru}-\mathrm{Ru}$ distance of 2.263(2) $\AA$, but the disorder makes this value dubious for the minor component.

(98) Li Manni, G.; Dzubak, A. L.; Mulla, A.; Brogden, D. W.; Berry, J. F.; Gagliardi, L. Chem. - Eur. J. 2012, 18, 1737-1749.

(99) Delgado-Jaime, M. U.; DeBeer, S. J. Comput. Chem. 2012, 33, $2180-2185$

(100) The energy of the $\delta^{*}(x y)$ orbital was chosen as a reference point to which the other energies are normalized because it is an almost entirely metal-based orbital that does not interact with the axial ligand, does not significantly change its small interaction with the equatorial ligands with respect to different axial ligands, and generally shows less mixing with other metal-based orbitals than does the $\delta(x y)$ orbital.

(101) Clark, D. L.; Green, J. C.; Redfern, C. M. J. Chem. Soc., Dalton Trans. 1989, 1037-1044.

(102) Bersuker, I. B. Chem. Rev. 2013, 113, 1351-1390.

(103) Syamala, A.; Chakravarty, A. R. Polyhedron 1995, 14, 231-237.

(104) Bear, J. L.; Chen, W.-Z.; Han, B.; Huang, S.; Wang, L.-L.; Thuriere, A.; Van Caemelbecke, E.; Kadish, K. M.; Ren, T. Inorg. Chem. 2003, 42, 6230-6240.

(105) Han, B.; Shao, J.; Ou, Z.; Phan, T. D.; Shen, J.; Bear, J. L.; Kadish, K. M. Inorg. Chem. 2004, 43, 7741-7751.

(106) Kadish, K. M.; Nguyen, M.; Van Caemelbecke, E.; Bear, J. L. Inorg. Chem. 2006, 45, 5996-6003.

(107) Kadish, K. M.; Phan, T. D.; Giribabu, L.; Shao, J.; Wang, L.-L.; Thuriere, A.; Van Caemelbecke, E.; Bear, J. L. Inorg. Chem. 2004, 43, $1012-1020$.

(108) Ngubane, S.; Kadish, K. M.; Bear, J. L.; Van Caemelbecke, E.; Thuriere, A.; Ramirez, K. P. Dalton Trans. 2013, 42, 3571-3580. 